Cochrane Database of Systematic Reviews

\title{
Intraoperative use of low volume ventilation to decrease postoperative mortality, mechanical ventilation, lengths of stay and lung injury in adults without acute lung injury (Review)
}

Guay J, Ochroch EA, Kopp S

Guay J, Ochroch EA, Kopp S.

Intraoperative use of low volume ventilation to decrease postoperative mortality, mechanical ventilation, lengths of stay and lung injury in adults without acute lung injury.

Cochrane Database of Systematic Reviews 2018, Issue 7. Art. No.: CD011151.

DOI: 10.1002/14651858.CD011151.pub3. 
TABLE OF CONTENTS

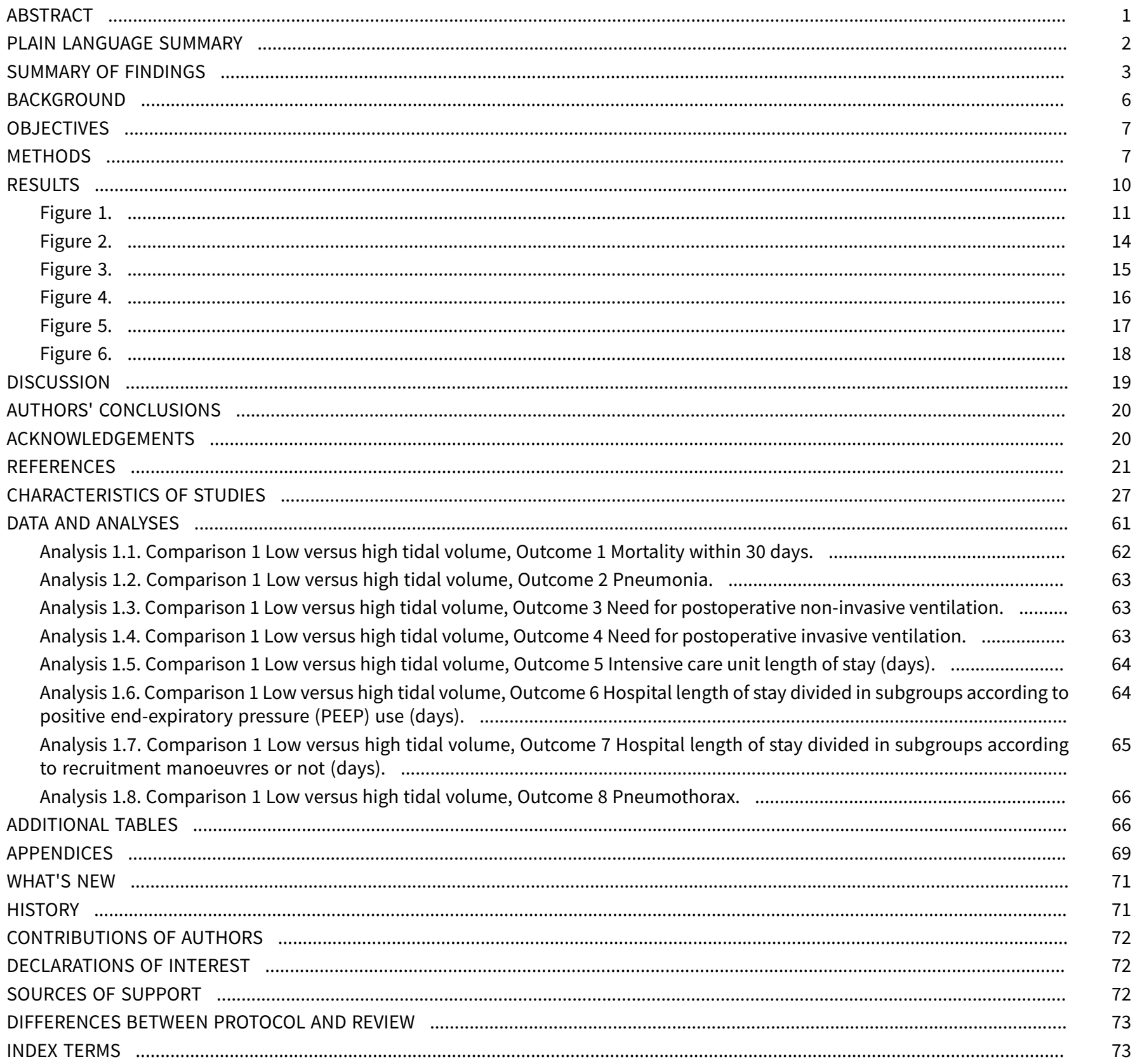


[Intervention Review]

\section{Intraoperative use of low volume ventilation to decrease postoperative mortality, mechanical ventilation, lengths of stay and lung injury in adults without acute lung injury}

Joanne Guay1,2,3, Edward A Ochroch4 ${ }^{4}$, Sandra Kopp 5

1Department of Anesthesiology, Faculty of Medicine, University of Sherbrooke, Sherbrooke, Canada. ${ }^{2}$ Teaching and Research Unit, Health Sciences, University of Quebec in Abitibi-Temiscamingue, Rouyn-Noranda, Canada. ${ }^{3}$ Department of Anesthesiology and Critical Care, Faculty of Medicine, Laval University, Quebec City, Canada. ${ }^{4}$ Department of Anesthesiology, University of Pennsylvania, Philadelphia, PA, USA. 5 Department of Anesthesiology and Perioperative Medicine, Mayo Clinic College of Medicine, Rochester, MN, USA

Contact: Joanne Guay, Department of Anesthesiology, Faculty of Medicine, University of Sherbrooke, Sherbrooke, Quebec, Canada. joanneguay@bell.net, joanneguay@att.net.

Editorial group: Cochrane Anaesthesia Group.

Publication status and date: Edited (no change to conclusions), published in Issue 10, 2018.

Citation: Guay J, Ochroch EA, Kopp S. Intraoperative use of low volume ventilation to decrease postoperative mortality, mechanical ventilation, lengths of stay and lung injury in adults without acute lung injury. Cochrane Database of Systematic Reviews 2018 , Issue 7. Art. No.: CD011151. DOI: 10.1002/14651858.CD011151.pub3.

Copyright @ 2018 The Cochrane Collaboration. Published by John Wiley \& Sons, Ltd.

\section{A B S T R A C T}

\section{Background}

Since the 2000s, there has been a trend towards decreasing tidal volumes for positive pressure ventilation during surgery. This an update of a review first published in 2015, trying to determine if lower tidal volumes are beneficial or harmful for patients.

\section{Objectives}

To assess the benefit of intraoperative use of low tidal volume ventilation (less than $10 \mathrm{~mL} / \mathrm{kg}$ of predicted body weight) compared with high tidal volumes (10 mL/kg or greater) to decrease postoperative complications in adults without acute lung injury.

\section{Search methods}

We searched the Cochrane Central Register of Controlled Trials (CENTRAL 2017, Issue 5), MEDLINE (OvidSP) (from 1946 to 19 May 2017 ), Embase (OvidSP) (from 1974 to 19 May 2017) and six trial registries. We screened the reference lists of all studies retained and of recent meta-analysis related to the topic during data extraction. We also screened conference proceedings of anaesthesiology societies, published in two major anaesthesiology journals. The search was rerun 3 January 2018.

\section{Selection criteria}

We included all parallel randomized controlled trials (RCTs) that evaluated the effect of low tidal volumes (defined as less than $10 \mathrm{~mL}$ $\mathrm{kg}$ ) on any of our selected outcomes in adults undergoing any type of surgery. We did not retain studies with participants requiring onelung ventilation.

\section{Data collection and analysis}

Two authors independently assessed the quality of the retained studies with the Cochrane 'Risk of bias' tool. We analysed data with both fixed-effect ( ${ }^{2}$ statistic less than $25 \%$ ) or random-effects ( $\left.\right|^{2}$ statistic greater than $\left.25 \%\right)$ models based on the degree of heterogeneity. When there was an effect, we calculated a number needed to treat for an additional beneficial outcome (NNTB) using the odds ratio. When there was no effect, we calculated the optimum information size. 


\section{Main results}

We included seven new RCTs (536 participants) in the update.

In total, we included 19 studies in the review (776 participants in the low tidal volume group and 772 in the high volume group). There are four studies awaiting classification and three are ongoing. All included studies were at some risk of bias. Participants were scheduled for abdominal surgery, heart surgery, pulmonary thromboendarterectomy, spinal surgery and knee surgery. Low tidal volumes used in the studies varied from $6 \mathrm{~mL} / \mathrm{kg}$ to $8.1 \mathrm{~mL} / \mathrm{kg}$ while high tidal volumes varied from $10 \mathrm{~mL} / \mathrm{kg}$ to $12 \mathrm{~mL} / \mathrm{kg}$.

Based on 12 studies including 1207 participants, the effects of low volume ventilation on 0 - to 30 -day mortality were uncertain (risk ratio (RR) $0.80,95 \%$ confidence interval ( $\mathrm{Cl}$ ) 0.42 to $1.53 ; \mathrm{I}^{2}=0 \%$; low-quality evidence). Based on seven studies including 778 participants, lower tidal volumes probably reduced postoperative pneumonia (RR $0.45,95 \% \mathrm{Cl} 0.25$ to $0.82 ; \mathrm{I}^{2}=0 \%$; moderate-quality evidence; NNTB 24 , $95 \% \mathrm{Cl} 16$ to 160 ), and it probably reduced the need for non-invasive postoperative ventilatory support based on three studies including 506 participants (RR $0.31,95 \% \mathrm{Cl} 0.15$ to 0.64 ; moderate-quality evidence; NNTB $13,95 \% \mathrm{Cl} 11$ to 24 ). Based on 11 studies including 957 participants, low tidal volumes during surgery probably decreased the need for postoperative invasive ventilatory support (RR $0.33,95 \% \mathrm{Cl}$ 0.14 to $0.77 ; 1^{2}=0 \%$; NNTB $39,95 \% \mathrm{Cl} 30$ to 166 ; moderate-quality evidence). Based on five studies including 898 participants, there may be little or no difference in the intensive care unit length of stay (standardized mean difference (SMD) $-0.06,95 \% \mathrm{Cl}-0.22$ to $0.10 ; 12=33 \%$; lowquality evidence). Based on 14 studies including 1297 participants, low tidal volumes may have reduced hospital length of stay by about 0.8 days (SMD $-0.15,95 \% \mathrm{Cl}-0.29$ to $0.00 ; \mathrm{I}^{2}=27 \%$; low-quality evidence). Based on five studies including 708 participants, the effects of low volume ventilation on barotrauma (pneumothorax) were uncertain (RR 1.77, $95 \% \mathrm{Cl} 0.52$ to $5.99 ; \mathrm{I}^{2}=0 \%$; very low-quality evidence).

\section{Authors' conclusions}

We found moderate-quality evidence that low tidal volumes (defined as less than $10 \mathrm{~mL} / \mathrm{kg}$ ) decreases pneumonia and the need for postoperative ventilatory support (invasive and non-invasive). We found no difference in the risk of barotrauma (pneumothorax), but the number of participants included does not allow us to make definitive statement on this. The four studies in 'Studies awaiting classification' may alter the conclusions of the review once assessed.

\section{PLAIN LANGUAGE SUMMAR}

\section{Use of small volumes of breath insufflation for intraoperative mechanical ventilation during surgery}

\section{Background}

Inspiration (breathing in) is produced by the shortening (contraction) of various muscles that stretch the lungs to increase their size like rubber balloons. During this phase, oxygen enters the lungs. When these muscles stop their contractions, the lungs go back to their initial size. During this phase, carbon dioxide goes out of the lungs. When people are cared for under general anaesthesia, some of the drugs used will stop the movements of the muscles controlling lung size. Insufflation is the act of mechanically forcing air into a person's respiratory system. A machine is required to replace the effects of the muscles. A mixture of gas containing oxygen is blown into the lungs. It is actually not known whether it is better to blow small volumes of gas at a higher rate or bigger volumes at a lower rate. In this review, we tried to determine whether this volume should be lower or higher than 10 millilitres per kilogram of body weight.

\section{Study characteristics}

We searched medical databases up to 19 May 2017. We included 19 studies with 1548 adults of both sexes. The participants had had operations on the abdomen (tummy), heart, blood vessels of the lungs, back, lower limbs or various surgeries. Two studies mentioned financial support from the pharmaceutical industry or from medical equipment manufacturers. We do not think that this had an effect on the results as high or low volumes may be administered with any machine.

\section{Key results}

We did not find a difference in 0 - to 30-day mortality (death within one month). We found that using a volume lower than 10 millilitres per kilogram of body weight reduced the risk of pneumonia (lung infection) and increased the chances that people would be able to get back to their normal respiratory status immediately after surgery. Low volumes should be used preferentially during surgery. For every 1000 people operated on, 84 would have pneumonia after the operation if high volumes were used during surgery. This number was reduced to 43 if low volumes were used instead. Likewise, the number of people needing additional non-invasive ventilatory support (through a mask applied to the face) would be reduced from 115 to 36 if volumes lower than 10 millilitres per kilogram of body weight were used during surgery and the need invasive ventilatory support (through a tube inserted in the person's windpipe) would be reduced from 39 to 13 . Hospital length of stay may be slightly reduced (equivalent to almost one day). We identified no possible harmful effects of using low volumes.

\section{Reliability of evidence}

We judged the reliability of the evidence as moderate for pneumonia and reduced need for ventilatory support (non-invasive or invasive). Results on these three outcomes may be affected with additional data. 


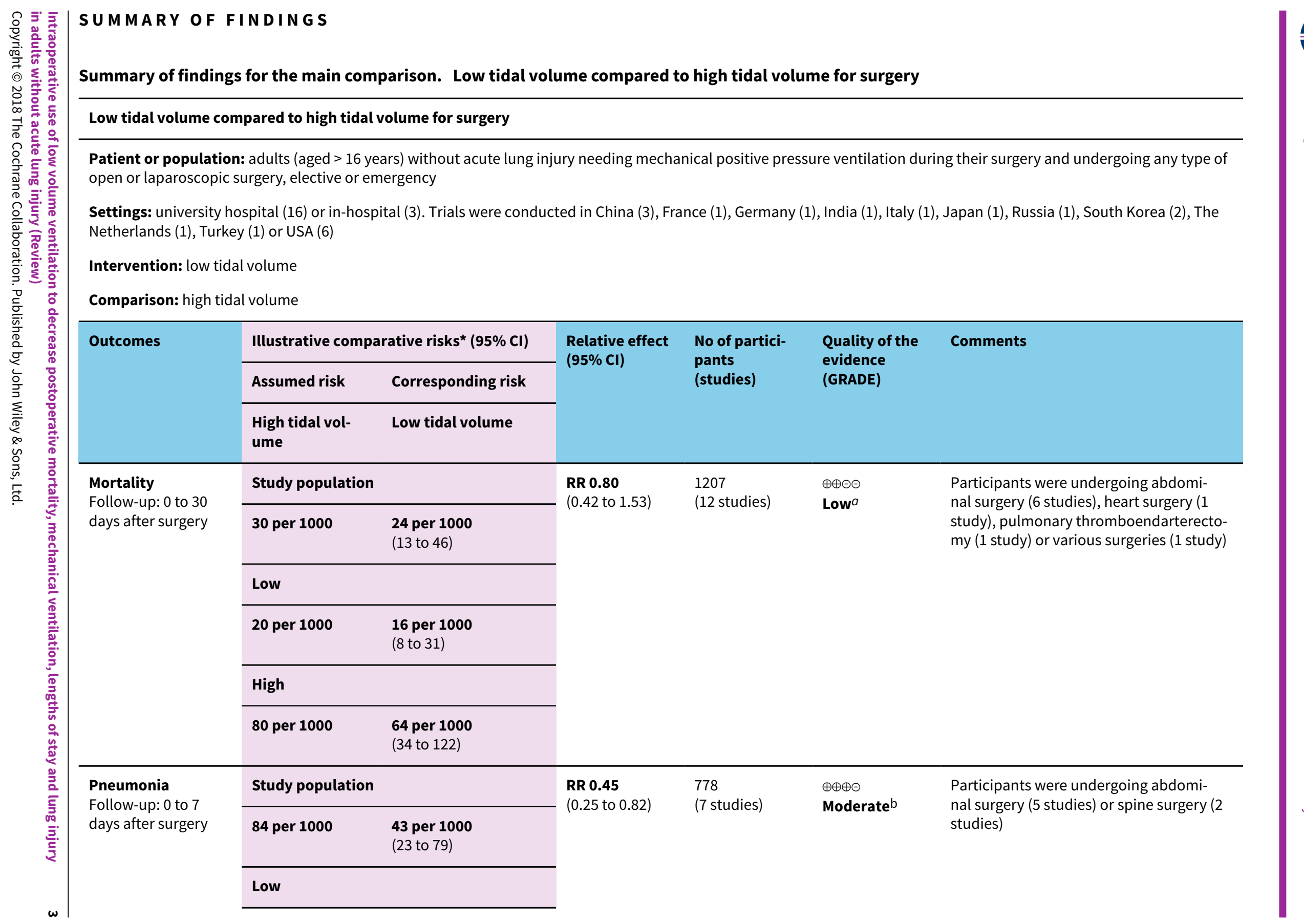




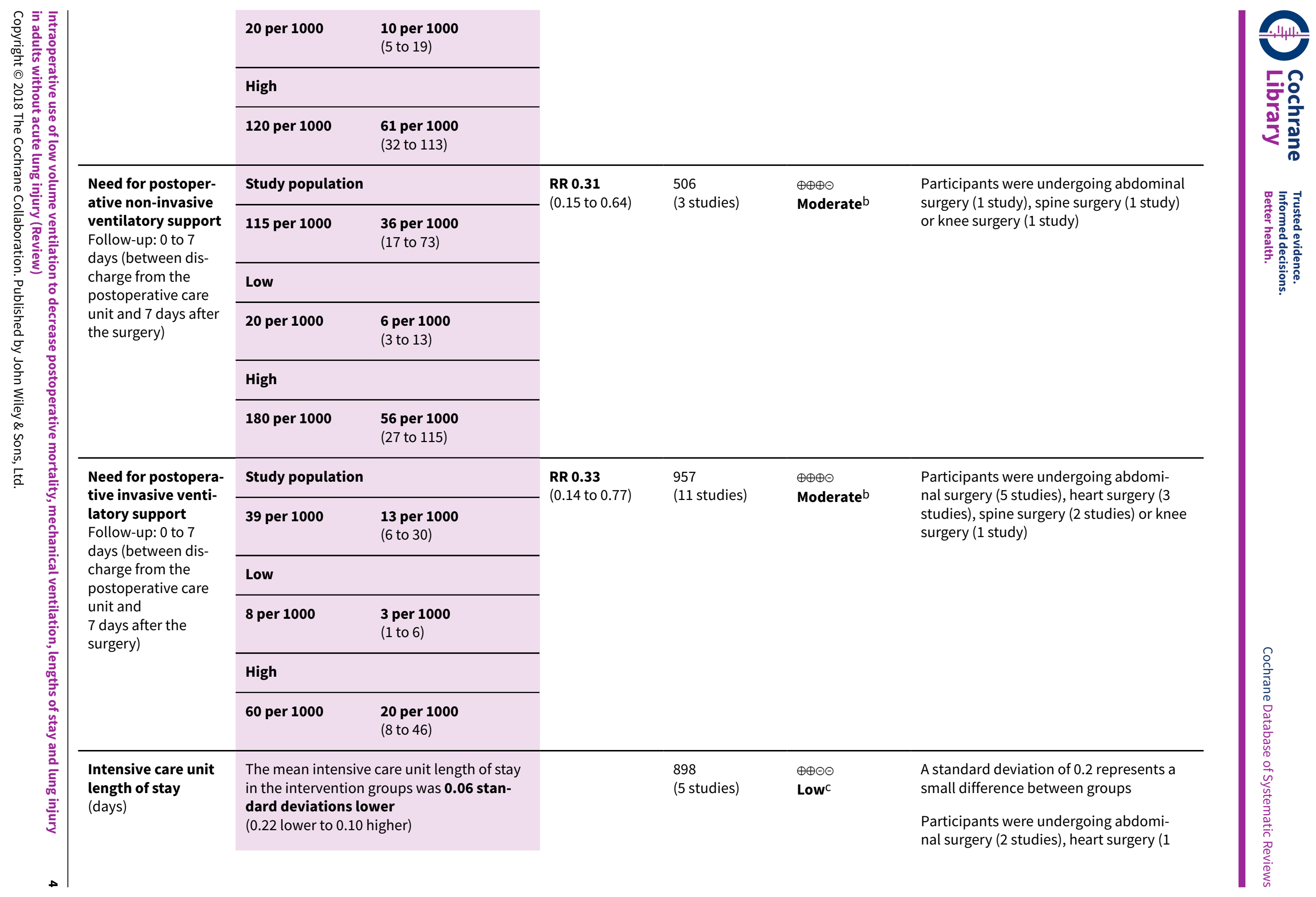




\begin{tabular}{|c|c|c|c|c|c|c|}
\hline \multirow[b]{2}{*}{$\begin{array}{l}\text { Hospital length of } \\
\text { stay } \\
\text { (days) }\end{array}$} & & & & & $\begin{array}{l}\text { study), pulmonary thromboendarterecto- } \\
\text { my ( } 1 \text { study) or various surgeries ( } 1 \text { study) }\end{array}$ \\
\hline & \multicolumn{2}{|c|}{$\begin{array}{l}\text { The mean hospital length of stay in the in- } \\
\text { tervention groups was } \\
\mathbf{0 . 1 5} \text { standard deviations lower } \\
\text { ( } 0.29 \text { lower to }-0.00 \text { lower) }\end{array}$} & & $\begin{array}{l}1298 \\
\text { (14 studies) }\end{array}$ & $\begin{array}{l}\oplus \oplus \ominus \ominus \\
\text { Low }^{c}\end{array}$ & $\begin{array}{l}\text { A standard deviation of } 0.2 \text { represents a } \\
\text { small difference between groups } \\
\text { Participants were undergoing abdominal } \\
\text { surgery ( } 7 \text { studies), heart surgery ( } 3 \text { stud- } \\
\text { ies), pulmonary thromboendarterecto- } \\
\text { my ( } 1 \text { study) spine surgery ( } 1 \text { study), knee } \\
\text { surgery ( } 1 \text { study) or various surgeries ( } 1 \\
\text { study) } \\
\text { The difference was equivalent to } 0.8 \text { day }\end{array}$ \\
\hline \multirow{6}{*}{$\begin{array}{l}\text { Barotrauma: pneu- } \\
\text { mothorax } \\
\text { Follow-up: } 0 \text { to } 7 \\
\text { days }\end{array}$} & \multicolumn{2}{|c|}{ Study population } & \multirow{6}{*}{$\begin{array}{l}\text { RR } 1.77 \\
(0.52 \text { to } 5.99)\end{array}$} & \multirow{6}{*}{$\begin{array}{l}708 \\
\text { (5 studies) }\end{array}$} & \multirow{6}{*}{$\begin{array}{l}\oplus \ominus \ominus \ominus \\
\text { Very low }\end{array}$} & \multirow{6}{*}{$\begin{array}{l}\text { Participants were undergoing abdominal } \\
\text { surgery ( } 4 \text { studies) or pulmonary throm- } \\
\text { boendarterectomy ( } 1 \text { study) }\end{array}$} \\
\hline & 11 per 1000 & $\begin{array}{l}20 \text { per } 1000 \\
(6 \text { to } 67)\end{array}$ & & & & \\
\hline & \multicolumn{2}{|l|}{ Low } & & & & \\
\hline & 5 per 1000 & $\begin{array}{l}9 \text { per } 1000 \\
(3 \text { to } 30)\end{array}$ & & & & \\
\hline & \multicolumn{2}{|l|}{ High } & & & & \\
\hline & 30 per 1000 & $\begin{array}{l}\mathbf{5 3} \text { per } 1000 \\
\text { (16 to } 180)\end{array}$ & & & & \\
\hline
\end{tabular}

The corresponding risk (and its 95\% confidence interval) is based on the assumed risk in the comparison group and the relative effect of the intervention (and its $95 \% \mathrm{Cl}$ ). Cl: confidence interval; RR: risk ratio; SMD: standardized mean difference.

GRADE Working Group grades of evidence

High quality: further research is very unlikely to change our confidence in the estimate of effect.

Moderate quality: further research is likely to have an important impact on our confidence in the estimate of effect and may change the estimate.

Low quality: further research is very likely to have an important impact on our confidence in the estimate of effect and is likely to change the estimate.

Very low quality: we are very uncertain about the estimate.

a Downgraded one level for risk of bias and by one level for imprecision.

bDowngraded one level for imprecision.

cDowngraded one level for risk of bias and by one level for heterogeneity.

$d$ Downgraded one level for risk of bias and by two levels for imprecision. 


\section{B A C K G R O U N D}

\section{Description of the condition}

When a person comes to the operating room for surgery, choices for anaesthesia are local anaesthesia (infiltration of local anaesthetic at the site of the surgery), regional anaesthesia (blockade of nerve conduction at the level of the spine, a plexus or a nerve) and general anaesthesia. For many surgeries under general anaesthesia a neuromuscular blocking agent is administered thus paralysing the respiratory muscles. To ensure appropriate delivery of oxygen and elimination of carbon dioxide artificial (mechanical) ventilation is necessary. In brief, a certain volume of gas will be insufflated into the lungs a certain number of times per minute to match the specific person's needs. Thus, the required amount of gas insufflated each minute can be delivered with high volumes at a low frequency or with small volumes at a higher frequency. In healthy non-anaesthetized people, the tidal volume (volume of gas delivered at each respiration) is approximately $5 \mathrm{~mL} / \mathrm{kg}$ to $6 \mathrm{~mL} / \mathrm{kg}$ of body weight (Aliverti 2011).

The drugs that are used to produce general anaesthesia, insertion of the tracheal tube, inhalation of cold non-humidified gas and the change from physiological negative pressure ventilation to artificial positive pressure ventilation will induce various physiological changes (Aliverti 2011). One of the many significant outcomes of these interventions (along with the direct effects from surgery) is lung collapse (atelectasis) in the dependent lung zones (Cai 2007). With positive pressure ventilation, gas will go preferentially to the uppermost parts of the lung (zones of lower resistance to lung expansion) while blood flow (following gravity) will go preferentially into the lowermost parts of the lungs, the atelectatic (closed) ones. The difference between non-dependent and dependent zones is far less pronounced for ventilation than it is for perfusion (Petersson 2010). Thus initiation of positive pressure ventilation in an anaesthetized person will increase the 'mismatch' between the ventilation (going preferentially to the non-dependent parts of the lungs) and the perfusion (going preferentially to the dependent parts of the lungs). We called this 'shunting'. The shunt is the fraction of the cardiac output not exposed to gas exchange in the pulmonary capillary bed. Although a certain amount of physiological shunting exists (the bronchial circulation, a fraction of the blood returning from the left myocardium and with a possible contribution of dormant arteriovenous intrapulmonary shunts (Eldridge 2004)), in healthy people, when the shunt increases the gas exchange (mainly oxygen entry into the blood vessels) will become suboptimal creating abnormally low levels of blood oxygen concentration (hypoxaemia).

Intraoperative atelectasis is reversible by passive hyperinflation, consisting of maintaining a positive pressure of $20 \mathrm{~cm} \mathrm{H}_{2} \mathrm{O}$ to $25 \mathrm{cmH}_{2} \mathrm{O}$ for 10 seconds, therefore Bendixen and colleagues hypothesized that supraphysiological tidal volumes would decrease intraoperative atelectasis and the subsequent increase in intrapulmonary shunt (Bendixen 1963). In their experiment, they included 18 healthy people (aged 24 to 87 years) coming for surgery and requiring muscle paralysis. Participants were divided into two groups, one receiving pure oxygen and halothane $1 \%$ while the other group received various proportions of nitrous oxide and oxygen. Pressure-controlled positive pressure ventilation was provided at a rate between 20 breaths per minute and 25 breaths per minute with a pressure between $15 \mathrm{cmH}_{2} \mathrm{O}$ and 20
$\mathrm{CmH}_{2} \mathrm{O}$ in both groups. Arterial partial pressure of oxygen $\left(\mathrm{PaO}_{2}\right)$, partial pressure of carbon dioxide $\left(\mathrm{PaCO}_{2}\right)$ and compliance were measured every 10 to 30 minutes starting after a 10-second hyperinflation at $20 \mathrm{cmH}_{2} \mathrm{O}$ to $25 \mathrm{cmH}_{2} \mathrm{O}$. Compliance $(15 \%$ decrease) and $\mathrm{PaO}_{2}$ (22\% decrease) fell over time. There was a linear relationship between the increase in $\mathrm{PaCO}_{2}$ and the decrease in $\mathrm{PaO}_{2}$, therefore the authors extrapolated that hyperventilation (resulting in lower carbon dioxide tension) would reduce the chances of having atelectasis and hypoxaemia. All their participants were ventilated at approximately the same rate, so they further deduced that the continuous hyperinflation that resulted from larger tidal volumes would be protective against atelectasis and intraoperative intrapulmonary shunt, whereas low tidal volumes would facilitate them. Thus, since the 1960 s, clinicians have relied on supraphysiological tidal volumes of $10 \mathrm{~mL} / \mathrm{kg}$ to $15 \mathrm{~mL} / \mathrm{kg}$ positive pressure ventilation in the hope of reducing intraoperative atelectasis and hypoxaemia (Bendixen 1963).

Although the time and oxygen inspired fraction dependent formation of atelectasis in healthy people under anaesthesia and ventilated with low tidal volumes $(7 \mathrm{~mL} / \mathrm{kg}$ to $10 \mathrm{~mL} / \mathrm{kg}$ ) (Edmark 2011), and no positive end-expiratory pressure (PEEP) (Rusca 2003), is now a well established fact (Brismar 1985; Gunnarsson 1991), the strength of the demonstration by Bendixen and colleagues that higher tidal volumes would reduce this phenomenon remains a point of controversy. By favouring oxygen absorption in the capillaries from the areas of low ventilation and perfusion (such as found in the dependent zones of the lungs of healthy anaesthetized people), a high oxygen inspired fraction $\left(\mathrm{FiO}_{2}\right)$ will hasten the formation of atelectasis (absorption atelectasis) (Edmark 2011). Bendixen and colleagues ventilated half of their participants with 99\% oxygen and this confounding factor was not taken into account in the analysis of their results, obtained from samples taken at varying intervals (Bendixen 1963). Furthermore, when PEEP is applied during volume-controlled mechanical ventilation of people under anaesthesia, a reduction in the formation of atelectasis in the PEEP group is accompanied by a lower $\mathrm{PaCO}_{2}$ despite the use of fixed identical tidal volumes $(10 \mathrm{~mL} / \mathrm{kg}$ at 10 breaths per minute) (Rusca 2003). This suggests that alveolar ventilation may be higher in people with reduced atelectasis, given identical delivered minute-volume ventilation. Bendixen and colleagues attributed the lower $\mathrm{PaCO}_{2}$ observed in some of their participants to the use of higher tidal volumes during pressure-controlled ventilation but they did not formally measure the tidal volumes administered (delivered or expired). Thus, a decreased amount of atelectasis (caused by a lower inspired oxygen concentration as an example) in some of the participants in the Bendixen study may have favoured both carbon dioxide elimination and oxygen absorption at the same time. The inverse relationship observed between $\mathrm{PaO}_{2}$ and $\mathrm{PaCO}_{2}$ in their participants may not be a causal relationship but simply two different results of another third factor, hastened formation of atelectasis in people receiving a higher inspired oxygen concentration. Bendixen and colleagues did not therefore produce any clear evidence that higher tidal volumes in anaesthetized people will reduce atelectasis formation.

In 2000, one large randomized trial involving people with acute lung injury reported decreased mortality in people ventilated with $6 \mathrm{~mL} / \mathrm{kg}$ and a maximal plateau pressure of $30 \mathrm{~cm} \mathrm{H}_{2} \mathrm{O}$ compared to people ventilated with $12 \mathrm{~mL} / \mathrm{kg}$ and a maximal plateau pressure 
of $50 \mathrm{cmH}_{2} \mathrm{O}(31.0 \%$ with $6 \mathrm{~mL} / \mathrm{kg}$ versus $39.8 \%$ with $12 \mathrm{~mL} /$ $\mathrm{kg} ; \mathrm{P}=0.007$ ) (Acute Respiratory Distress Syndrome Network). Although this trial was prematurely stopped after the enrolment of 861 participants, one subsequent Cochrane Review confirmed that clinical trials on people with acute lung injury showed that a combination of physiological tidal volume $(7 \mathrm{~mL} / \mathrm{kg}$ or less of predicted body weight), sufficient PEEP to prevent alveolar repetitive closing-opening injury and plateau pressure less than 30 $\mathrm{cmH}_{2} \mathrm{O}$ improved the outcome with a risk ratio (RR) for mortality at day 28 of 0.74 ( $95 \%$ confidence interval $(\mathrm{Cl}) 0.61$ to 0.88 ) (Petrucci 2013). Based on the findings of the ARMA trial (Acute Respiratory Distress Syndrome Network), clinicians have been inclined to apply these results to people without acute lung injury and have started to use lower tidal volume ventilation intraoperatively. In one large retrospective trial, Levin and colleagues found that in their institution the median tidal volume per kilogram of ideal body weight decreased from $9.0 \mathrm{~mL} / \mathrm{kg}$ in 2008 to $8.3 \mathrm{~mL} / \mathrm{kg}$ in 2011 $(P<0.01)$ (Levin 2014). This newer clinical practice is supported by a multicentre clinical trial performed on people without acute lung injury that included 400 participants and showed that the use of a strategy that included low tidal volumes could reduce the risk of a composite of major pulmonary and extrapulmonary complications occurring within seven days of surgery in people at high or moderate risk of complications and undergoing abdominal surgery lasting two hours or more (Futier 2013). This strategy included tidal volumes of $6 \mathrm{~mL} / \mathrm{kg}$ to $8 \mathrm{~mL} / \mathrm{kg}$ of ideal body weight, positive PEEP of $6 \mathrm{cmH}_{2} \mathrm{O}$ to $8 \mathrm{cmH}_{2} \mathrm{O}$ and recruitment manoeuvres repeated every 30 minutes versus tidal volumes of $10 \mathrm{~mL} / \mathrm{kg}$ to $12 \mathrm{~mL} / \mathrm{kg}$, no PEEP and no recruitment manoeuvres (Futier 2013). A recommendation on the use of lower tidal volume in people without acute lung injury for mechanical ventilation during surgery is, however, still a controversial issue. By using a propensity score analysis on their institutional data for 29,343 participants, Levin and colleagues reported that the use of low intraoperative tidal volume with minimal PEEP (median 4, interquartile range (IQR) $2.2 \mathrm{cmH}_{2} \mathrm{O}$ to $5 \mathrm{cmH}_{2} \mathrm{O}$ ) was associated with an increased risk of 30-day mortality (Levin 2014). Low tidal volumes of $6 \mathrm{~mL} / \mathrm{kg}$ to $8 \mathrm{~mL} / \mathrm{kg}$ of ideal body weight were associated with a significant increase in 30-day mortality versus tidal volumes of $8 \mathrm{~mL} / \mathrm{kg}$ to $10 \mathrm{~mL} / \mathrm{kg}$ of ideal body weight with a hazard ratio of $1.6(95 \% \mathrm{Cl}$ 1.25 to 2.08 ; $P=0.0002$ ). In this large retrospective trial, the doseresponse curve indicated a threshold tidal volume of $9.7 \mathrm{~mL} / \mathrm{kg}$ of body weight (Levin 2014). However, it is relevant to note that all their participants were ventilated with a relatively high $\mathrm{FiO}_{2}$. The median $\mathrm{FiO}_{2}$ in the tidal volume $3 \mathrm{~mL} / \mathrm{kg}$ to $6 \mathrm{~mL} / \mathrm{kg}$ of body weight group was 0.76 versus 0.73 in the group with a tidal volume of 12 $\mathrm{mL} / \mathrm{kg}$ to $20 \mathrm{~mL} / \mathrm{kg}$ (Levin 2014). This is in contrast to Futier and colleague's study where the mean $\mathrm{FiO}_{2}$ used was 0.46 versus 0.47 , making the exact contribution of the tidal volume unclear (Futier 2013).

\section{Description of the intervention}

We evaluated using low tidal volumes for the intraoperative mechanical ventilation of people without acute lung injury. We defined a low tidal volume as less than $10 \mathrm{~mL} / \mathrm{kg}$ of predicted body weight per breath (insufflation).

\section{How the intervention might work}

Administration of larger tidal volumes requires higher airway positive pressure (Levin 2014). This overpressure distributes preferentially in the more compliant lung zones, therefore alveoli contained in these more compliant lung zones may become overdistended with stretching and sheer forces on the alveolar wall (volutrauma), even possibly leading to disruption of the alveolar wall with air diffusing into the extra-alveolar tissues (barotrauma). The overall lung damage induced by mechanical ventilation is called ventilator-induced lung injury (VILI). Increased incidence of pulmonary complications may lead to increased duration of postoperative tracheal intubation, increased rate of infection (ventilator-associated pneumonia (VAP)) and eventually an increased death rate.

\section{Why it is important to do this review}

With improvement of the equipment and the availability of adding intraoperative PEEP adjusted to decrease alveolar closure (Tusman 2014), the relevance of keeping to the clinical practice of using high tidal volumes has been questioned. Conflicting results have, however, been reported with the use of low tidal volumes. Some authors reported that the use of a strategy including low tidal volumes reduced the risk of a composite of major pulmonary and extrapulmonary complications occurring within seven days of surgery in people at high or moderate risk of complications and undergoing abdominal surgery lasting two hours or more (Futier 2013). Others have reported that low tidal volumes with minimal PEEP may increase postoperative mortality (Levin 2014). By summing the evidence from all available trials, it could then perhaps be possible to determine which strategy (low or high tidal volumes) is the most beneficial for everyday clinical practice.

\section{O B JECT IVES}

To assess the benefit of intraoperative use of low tidal volume ventilation (less than $10 \mathrm{~mL} / \mathrm{kg}$ of predicted body weight) compared with high tidal volumes $(10 \mathrm{~mL} / \mathrm{kg}$ or greater) to decrease postoperative complications in adults without lung injury.

\section{METHODS}

\section{Criteria for considering studies for this review}

\section{Types of studies}

We included all parallel randomized controlled trials (RCTs) that evaluated the effect of low tidal volumes on any of our selected outcomes. We excluded observational studies, quasi-randomized trials, cross-over trials and cluster-randomized trials. We did not exclude any study based on language of publication or publication status.

\section{Types of participants}

We included studies performed on adults (aged over 16 years) needing mechanical positive pressure ventilation during their surgery and undergoing any type of open or laparoscopic surgery, elective or emergency, with the exception of participants undergoing surgery with one-lung ventilation. We included participants managed with laryngeal mask airways or endotracheal tubes and participants ventilated with or without continuous muscle relaxation (infusion or repeated doses throughout the surgery). We excluded studies performed on participants with acute lung injury. 


\section{Types of interventions}

We included studies where low tidal volumes, defined as less than $10 \mathrm{~mL} / \mathrm{kg}$ of predicted body weight, in the treatment group were compared to high tidal volumes, defined as $10 \mathrm{~mL} / \mathrm{kg}$ or greater of the predicted body weight, in the control group. Provided that the tidal volume was measured, we retained studies whether the ventilation was pressure or volume-controlled and whether or not any other ventilation modalities were added such as PEEP at any level (Barbosa 2014), recruitment manoeuvres or other.

\section{Types of outcome measures}

\section{Primary outcomes}

1. Mortality within 30 days after the surgery.

\section{Secondary outcomes}

1. Pneumonia (authors definition) within seven days after the surgery.

2. Need for postoperative non-invasive ventilation between discharge from the postoperative care unit and seven days after the surgery.

3. Need for postoperative invasive ventilation between discharge from the postoperative care unit and seven days after the surgery.

4. Intensive care unit (ICU) length of stay in days.

5. Hospital length of stay in days.

6. Barotrauma, defined as the clinically (or radiologically) diagnosed presence or absence of pneumothorax, pneumomediastinum or subcutaneous emphysema within seven days after the surgery.

\section{Search methods for identification of studies}

\section{Electronic searches}

The search strategy was developed in consultation with the Information Specialist. We identified RCTs through literature searching with systematic and sensitive search strategies as outlined in Section 6.4 of the Cochrane Handbook of Systematic reviews of Interventions (Higgins 2011). We applied no restrictions to language or publication status. We searched the following databases for relevant trials: Cochrane Central Register of Controlled Trials (CENTRAL 2017, Issue 5) (Appendix 1), MEDLINE (OvidSP) (from 1946 to May 2017) (Appendix 2), and Embase (OvidSP) (from 1974 to May 2017) (Appendix 3). We looked at PsycINFO (from inception in May 2017) as source of possible grey literature (Appendix 4).

The search was rerun 3 January 2018 with a different search strategy (Appendix 5).

\section{Searching other resources}

We searched trial registries ClinicalTrials.gov (www.clinicaltrials.gov), ISRCTN Registry (isrctn.org), UMIN Clinical Trials Registry (www.umin.ac.jp/ctr/index.htm), Australian New Zealand Clinical Trials Registry (www.anzctr.org.au/), Nederlands Trial Register (www.trialregister.nl/), and European Clinical Trials Database (eudract.ema.europa.eu/) for trials in progress in September 2014 and June 2017. We screened the reference lists of all studies retained and of recent meta-analysis related to the topic during data extraction. We also screened conference proceedings of anaesthesiology societies, published in two major anaesthesiology journals: British Journal of Anaesthesiology (2012 to 2016), andEuropean Journal of Anaesthesiology (2012 to 2017) and the website of the American Society of Anesthesiologists (2012 to 2016).

\section{Data collection and analysis}

\section{Selection of studies}

Two authors (JG and SK for this update) independently screened the list of all titles and abstracts identified by the search. We (JG and SK) retrieved and independently read any potential articles to determine their eligibility. We resolved discrepancies by discussion; the input of the third author (EAO) was not required. We listed the reasons for exclusions in the Characteristics of excluded studies table.

\section{Data extraction and management}

Two authors (JG and SK) independently selected the studies, extracted data (Assessment of risk of bias in included studies; Types of outcome measures; Assessment of heterogeneity), and entered the data in our data extraction sheet. We first entered the site where the study was performed and the date of data collection (to facilitate exclusion of duplicate publications), then whether the study was kept or the reason for rejection. After agreement, one author (JG) entered data and moderators for exploration of heterogeneity into Comprehensive Meta-analysis. Also, after agreement, the same author (JG) entered our evaluation of the risk of bias into Review Manager 5 (Review Manager 2014). We resolved any disagreements by discussion and the help of the third author (EAO) was not required. We contacted authors to obtain additional information when required. We then transferred data for analysis into Review Manager 5 in the format required, to include the maximal numbers of studies (events and total number of participants for each group; means, standard deviations and number of participants included in each group; or generic inverse variance if necessary). When possible, we entered the data as an intention-to-treat (ITT) analysis.

\section{Assessment of risk of bias in included studies}

Two authors (JG and SK) independently assessed the quality of the retained studies with the Cochrane 'Risk of bias' tool (Higgins 2011; Review Manager 2014). We resolved any disagreements by discussion. We considered a trial as having a low risk of bias if we assessed all of the following criteria as adequate and at risk of bias if we assessed one or more of the criteria as inadequate. We assessed the risk of bias based on the information presented in the reports, with no assumptions.

1. Generation of the allocation sequence of the interventions: we considered randomization adequate if it was generated by a computer or random number table algorithm. We judged other processes, such as tossing of a coin, adequate if the whole sequence was generated prior to the start of the trial. We considered the trial as quasi-randomized if a non-random system, such as dates, names or identification numbers, was used.

2. Concealment of allocation: we considered concealment adequate if the process that was used prevented participant recruiters, investigators and participants from knowing the intervention allocation of the next participant to be enrolled 
in the study. We considered concealment inadequate if the allocation method allowed the participant recruiters, investigators or participants to know the treatment allocation of the next participant to be enrolled in the study.

3. Blinding of participants and personnel: we considered blinding adequate if the participant and the personnel taking care of the participant were each blinded to the intervention. We considered blinding inadequate if the participants or the personnel were not each blinded to the intervention.

4. Blinding of outcome assessment: we considered blinding adequate if the outcome assessor was blinded to the intervention. We considered blinding inadequate if the outcome assessor was not blinded to the intervention.

5. Incomplete outcome data (attrition bias): we considered the trial adequate if all dropouts or withdrawals were accounted for, the number of dropouts was small (less than 20\%), similar for both interventions and the reasons for the dropping out of the participants seemed reasonable. We considered the trial inadequate for this specific item if the reasons for dropping out of the participant were not stated or did not sound reasonable, the number was high (20\% or greater) or highly different between the groups.

6. Selective reporting (reporting bias): we considered the trial as low risk of bias if all the measurements stated in the methods section were included in the results and at high risk if only a part of the results mentioned in the methods section were given in the results section.

7. Any other risk of bias: any other reason that may have influenced the results. We considered an apparent conflict of interest as a risk of bias.

\section{Measures of treatment effect}

We gave results as risk ratio (RR) with a 95\% confidence interval (Cl) for dichotomous data and mean difference with $95 \% \mathrm{Cl}$ for continuous data as far as was feasible. If some of the continuous data were given on different scales, we reported the results as a standardized mean difference (SMD) and $95 \% \mathrm{Cl}$. For SMD, we considered 0.2 a small effect, 0.5 a medium effect and 0.8 or greater a large effect (Pace 2011). When there was an effect, we calculated a number needed to treat for an additional beneficial outcome (NNTB) or number needed to treat for an additional harmful outcome (NNTH) from the odds ratio (EMB Website). When there was no effect, we calculated the optimum information size in order to make sure that there were enough participants included in the retained studies to justify a conclusion on the absence of effect (Pogue 1998; Rollin Brant). We considered a difference of $1 \%$ for the mortality rate and $15 \%$ (increase or decrease) for the other outcomes as the minimal clinically relevant difference.

\section{Unit of analysis issues}

We included only parallel-group trials. If a study contained more than two groups, we fused the two groups (by using the appropriate formula for adding the standard deviations when required) when we thought that they were equivalent according to the criteria of our protocol (taking our factors for heterogeneity exploration into account) or separated them and split the control group in half if we thought that they were different.

\section{Dealing with missing data}

We did not use medians as equivalent to means. Instead, we used the $P$ value and the numbers of participants included in each group to calculate the effect size. We did not use imputed results. We entered data as ITT as far as was feasible. If not, we noted it in other risks of bias and then entered the data on a per protocol basis. We included $P$ values when means and standard deviations were not provided. Authors were contacted to obtain additional information when we were unable to extract data.

\section{Assessment of heterogeneity}

We considered clinical heterogeneity before pooling results and examined statistical heterogeneity before carrying out any metaanalysis. We quantified statistical heterogeneity using the $1^{2}$ statistic with data entered in the way (benefit or harm) yielding the lowest amount (switching event and non-event) (Deeks 2002). We qualified the amount as low ( $25 \%$ or less), moderate ( $25 \%$ to $74 \%)$ or high $\left(75 \%\right.$ or greater) depending of the value obtained for the $1^{2}$ statistic (Higgins 2003).

\section{Assessment of reporting biases}

We examined publication bias with the Duval and Tweedie's trim and fill technique for each outcome (Duval 2000a; Duval 2000b). Publication bias is the risk of bias introduced by the possibility that medical journals publish studies favouring one treatment more often than studies favouring the other. When there is no publication bias and no small-study effect, if a graph is constructed with either the standard error or the precision (1/standard error) on the $y$-axis and the logarithm of the odds ratio on the $x$-axis, then studies should be equally distributed on both sides of a vertical line passing through the effect size found (log odds ratio). The entire graph should have the shape of a reversed funnel. The Duval and Tweedie's trim and fill analysis corrects the asymmetry by removing the extremely small studies from the positive side (recomputing the effect size at each iteration until the funnel plot is symmetric around the new effect size). The algorithm then adds the original studies back into the analysis and imputes a mirror image for each. The latter step does not modify the 'new effect size' but corrects the variance that was falsely reduced by the first step. The Duval and Tweedie's trim and fill analysis gives an estimate of what the effect size would be (odds ratio, RR, etc.) if there was no publication bias (Borenstein 2009).

\section{Data synthesis}

We analysed the data with Review Manager 5 (Review Manager 2014) and Comprehensive Meta Analysis Version 2.2.044 (www.meta-analysis.com), with fixed-effect models for comparisons with a low amount of heterogeneity as assessed by the $1^{2}$ statistic (less than $25 \%$ ) or random-effects models for comparisons containing a moderate or high amount of heterogeneity ( 12 statistic $25 \%$ or greater) (Higgins 2003). Fixedeffect and random-effects models give the same results in the absence of statistical heterogeneity $\left(I^{2}=0 \%\right)$. When there is statistical heterogeneity, random-effects models will usually widen the $\mathrm{Cl}$, thus decreasing the chance of finding an effect when there is none. They may, however, increase the weight of smaller studies. We presented the characteristics of included and excluded studies in tables. We presented the 'Risk of bias' assessment in a 'Risk of bias' graph. We presented results for each comparison as forest plots when appropriate. For comparisons with only one

Intraoperative use of low volume ventilation to decrease postoperative mortality, mechanical ventilation, lengths of stay and lung injury $\mathbf{9}$ in adults without acute lung injury (Review)

Copyright (c) 2018 The Cochrane Collaboration. Published by John Wiley \& Sons, Ltd. 
study available, or that still included a moderate or high level of heterogeneity after heterogeneity exploration, we provided the results as a narrative review.

\section{Subgroup analysis and investigation of heterogeneity}

We explored any amount of heterogeneity but we focused more specifically on comparisons with significant heterogeneity $\left(\mathrm{I}^{2}\right.$ greater than 25\%) (Higgins 2003). We explored heterogeneity using Egger's regression intercept (to assess the possibility of a small-study effect; Rucker 2011), visual inspection of the forest plots with studies placed in order according to a specific moderator, subgroupings (categorical moderators) or metaregressions (continuous moderators). Factors that we considered in the heterogeneity exploration were: exact tidal volume (or less than $6 \mathrm{~mL} / \mathrm{kg}, 6 \mathrm{~mL} / \mathrm{kg}$ to less than $8 \mathrm{~mL}, 8 \mathrm{~mL} / \mathrm{kg}$ to less than $10 \mathrm{~mL} / \mathrm{kg}$, $10 \mathrm{~mL} / \mathrm{kg}$ to less than $12 \mathrm{~mL} / \mathrm{kg}, 12 \mathrm{~mL} / \mathrm{kg}$ to less than $15 \mathrm{~mL} / \mathrm{kg}, 15$ $\mathrm{mL} / \mathrm{kg}$ or greater); pressure versus volume-controlled ventilation; presence or absence of chronic obstructive pulmonary disease or emphysema; peak and plateau inspiratory pressure (maximal measured); PEEP (amount, less than $5 \mathrm{cmH}_{2} \mathrm{O}$ versus $5 \mathrm{cmH}_{2} \mathrm{O}$ or greater, and technique used to determine the level); recruitment manoeuvres; inspired oxygen concentration; use of nitrous oxide; type and site of surgery (possibility of decreased chest compliance or increased intra-abdominal pressure (laparoscopic surgery), or both); elective versus emergent surgery; length of surgery; body mass index (BMI); use of cardiopulmonary bypass; use of epidural analgesia; surgical position; tidal volume adjusted for predicted body weight or not; use of neuromuscular blocking agents or not; tracheal tube versus laryngeal mask airway; and age.

\section{Sensitivity analysis}

We had planned a sensitivity analysis (based mainly on the 'Risk of bias' assessment: allocation concealment and blinding of the assessor) but we did not perform this as we considered no study to be of completely unacceptable quality and all the statistical heterogeneity could be explained based on clinical differences between the studies.

\section{'Summary of findings' table and GRADE}

We judged the quality of the body of evidence according to the system developed by the GRADE working group and presented this in a 'Summary of findings' table (ims.cochrane.org/revman/ gradepro), for each outcome: mortality, pneumonia, need for postoperative non-invasive ventilation, need for postoperative invasive ventilation, ICU length of stay, hospital length of stay and barotrauma. Briefly, the study design comes first: RCTs are moderate- or high-quality evidence (Guyatt 2011). The evidence is lower quality if the risk of bias of included studies is high or very high, there is some heterogeneity ( $1275 \%$ or greater without an explanation), the demonstration of effect is indirect, there is imprecision in the results $(95 \% \mathrm{Cl}$ around the effect size) or there is a risk of publication bias (classical fail-safe number or funnel plot). When the quality of the body of evidence is high, further research is very unlikely to change our confidence in the estimate of effect. When the quality is moderate, further research is likely to have an important impact on our confidence in the estimate of effect and may change the estimate. When the quality is low, further research is very likely to have an important impact on our confidence in the estimate of effect and is likely to change the estimate. When the quality is very low, any estimate of effect is very uncertain (Guyatt 2008).

\section{RE S U L T S}

\section{Description of studies}

\section{Results of the search}

The flow diagram of the study selection process is provided in Figure 1. 
Figure 1. Diagram of the flow search. RCT: randomized controlled trial. The original search (2014) performed for the first published version (2015) was rerun 19 May 2017. *A search with a modified strategy was run 8 January 2018: one trial classified as ongoing has been published is now awaiting classification. We found two new trials published between May 2017 and January 2018 and added them to the list of studies awaiting classification.

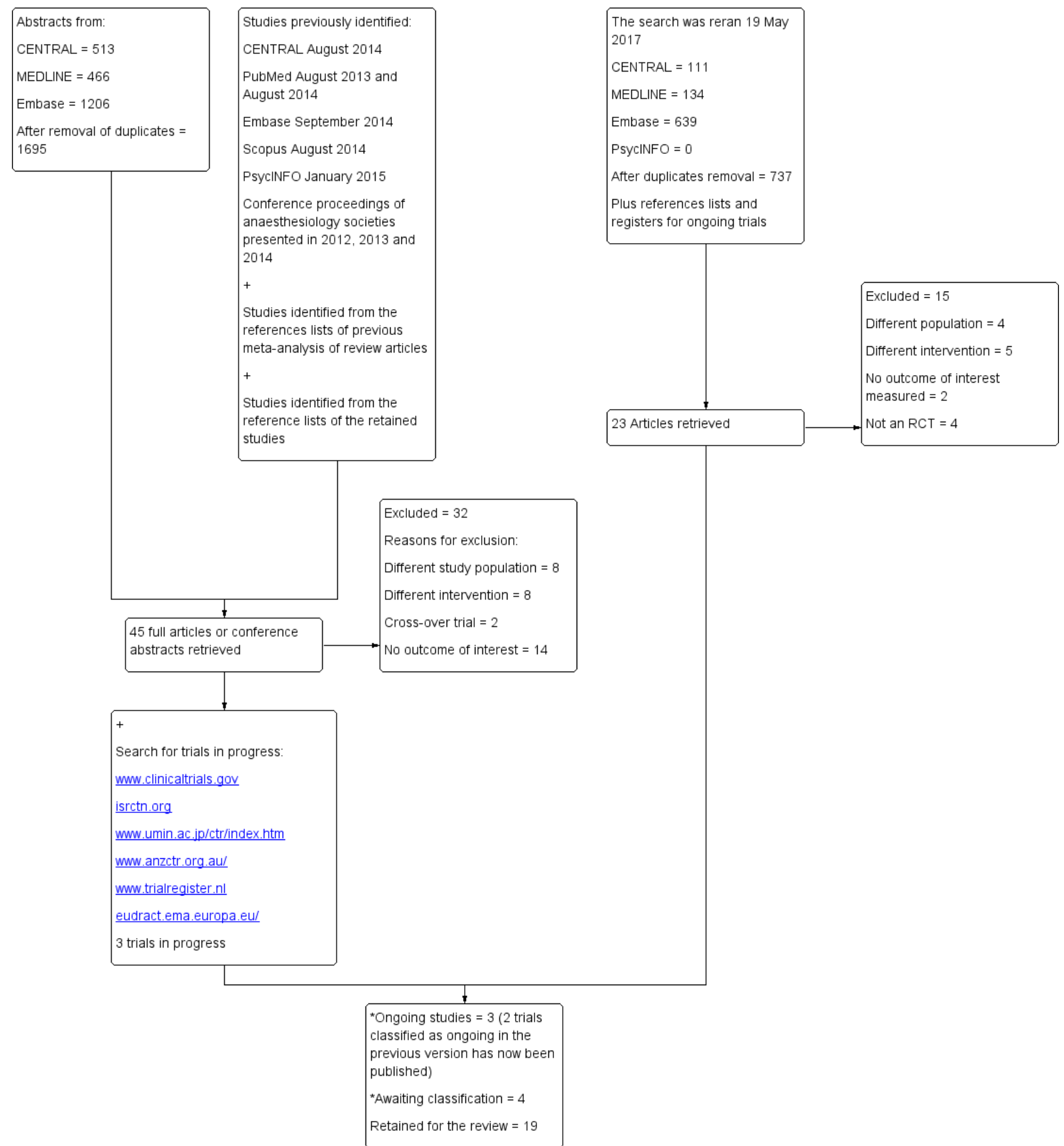

In the previous version (Guay 2015), we had 12 included trials, 1 trial awaiting classification, 3 ongoing trials and 32 excluded trials.

When we reran the search 19 May 2017, we identified 884 potentials titles (737 after duplicates removal). From titles/abstracts, 23 articles were retrieved for further evaluation of which 15 trials were excluded: different study population $(\mathrm{N}=4)$, different intervention
$(\mathrm{N}=5)$, no outcome of interest measured $(\mathrm{N}=2)$ or not a $\mathrm{RCT}(\mathrm{N}=4)$. Please see Characteristics of excluded studies for further details.

We now have 19 included trials, 47 excluded trials, 4 trials awaiting classification and 3 ongoing trials. 


\section{Included studies}

\section{Population and settings}

We included 19 studies with 1548 participants equally distributed between the two groups: 776 participants in the low tidal volume groups and 772 in the high volume groups. The mean age of the participants included in the studies varied from 35.5 to 73.0 years. Eight studies scheduled participants for abdominal surgery (Choi 2006; Chugh 2012; Futier 2013; Kuzkov 2016; Park 2016a; Sato 2016; Treschan 2012; Weingarten 2010), eight studies for heart surgery (Chaney 2000; Koner 2004; Sundar 2011; Zupancich 2005), four studies for spinal surgery (Ge 2013; Memtsoudis 2012; Soh 2018; Xiong 2016), and one study for knee surgery (FernandezBustamante 2014). One study included participants undergoing pulmonary thromboendarterectomy (Bates 2015), and one study included mixed surgeries (Shen 2015). One study performed laparoscopic abdominal surgery for $42.5 \%$ of the participants (Futier 2013), and another study for all participants (Park 2016a). One study used epidural anaesthesia/analgesia for $40 \%$ of the participants (Futier 2013), one study for $82.2 \%$ of participants (Treschan 2012), and three studies for all participants (Choi 2006; Kuzkov 2016; Sato 2016).

\section{Interventions and comparators}

Low tidal volumes varied from $6 \mathrm{~mL} / \mathrm{kg}$ to $8.1 \mathrm{~mL} / \mathrm{kg}$ while high tidal volumes varied from $10 \mathrm{~mL} / \mathrm{kg}$ to $12 \mathrm{~mL} / \mathrm{kg}$ except for one study (Bates 2015), where the mean measured delivered volume of the high volume group was $9.6 \mathrm{~mL} / \mathrm{kg}$ (target $10 \mathrm{~mL} / \mathrm{kg}$ ). The $\mathrm{FiO}_{2}$ administered during the surgery varied from 0.3 to 1.0 . Eleven studies administered PEEP varying from $3 \mathrm{cmH}_{2} \mathrm{O}$ to 12 $\mathrm{CmH}_{2} \mathrm{O}$ in the low tidal groups only (Choi 2006; Chugh 2012; Futier 2013; Ge 2013; Memtsoudis 2012; Park 2016a; Shen 2015; Soh 2018; Weingarten 2010; Xiong 2016; Zupancich 2005), four studies administered PEEP to both groups (Chaney 2000; FernandezBustamante 2014; Sundar 2011; Treschan 2012), and one study administered PEEP to the low tidal volume group and half of the participants of the high tidal volume group (Koner 2004). For Bates 2015, all participants received PEEP according to the recommendations of the ARDS Network (Acute Respiratory Distress Syndrome Network). Six studies used recruitment manoeuvres in the intervention group (Futier 2013; Ge 2013; Shen 2015; Soh 2018; Weingarten 2010; Xiong 2016), one study in the high tidal volume group (Park 2016a), and three studies in both groups (Bates 2015; Sato 2016; Treschan 2012). Nine studies did not use, or did not mention using, recruitment manoeuvres (Chaney 2000; Choi 2006; Chugh 2012; Fernandez-Bustamante 2014; Koner 2004; Kuzkov 2016; Memtsoudis 2012; Sundar 2011; Zupancich 2005).

\section{Funding sources}

Four studies were supported by charitable funding (FernandezBustamante 2014; Memtsoudis 2012; Park 2016a; Sato 2016). Three studies received governmental support (Kuzkov 2016; Xiong 2016; Zupancich 2005). Seven studies were supported by institutional/ departmental resources only (Chaney 2000; Choi 2006; Shen 2015; Soh 2018; Sundar 2011; Treschan 2012; Weingarten 2010). One study was supported by a pharmaceutical company (Koner 2004). For one study, some authors declared consultant fees or travel expenses, or both, from industry (Futier 2013). Three studies did not mention source of funding (Bates 2015; Chugh 2012; Ge 2013).

\section{Setting}

Trials were conducted in China (three; Ge 2013; Shen 2015; Xiong 2016), France (one; Futier 2013), Germany (one; Treschan 2012), India (one; Chugh 2012), Italy (one; Zupancich 2005), Japan (one; Sato 2016), Russia (one; Kuzkov 2016), South Korea (two; Park 2016a; Soh 2018), The Netherlands (one; Choi 2006), Turkey (one; Koner 2004) or the USA (six; Bates 2015; Chaney 2000; FernandezBustamante 2014; Memtsoudis 2012; Sundar 2011; Weingarten 2010).

\section{Excluded studies}

We excluded 47 studies. See the Characteristics of excluded studies table for details of the reasons for exclusion.

Twelve trials studied a different population (Determann 2010; Kang 2014; Kim 2012; Lee 1990; Lin 2008; Mascia 2010; Maslow 2013; Michelet 2006; Pinheiro 2010; Weismann 2010; Wrigge 2005; Yang 2011). Thirteen trials studied a different intervention (Akca 2013; Blum 2013; Ding 2016; Ferrando 2015; Hosten 2017; Jain 2016; Liu 2016; Reis Miranda 2005a; Reis Miranda 2005b; Satoh 2012; Severgnini 2013; Tugrul 1998; Tusman 1999). There were two crossover trials (Tweed 1991; Visick 1973). Sixteen trials did not measure any outcome of interest for this review (Arora 2017; Baki 2014; Cai 2007; Clarke 1998; Cui 2015; Ela 2014; Gong 2007; Jiang 2007; Kaisers 2009; Kanaya 2011; Kokulu 2015; Shin 2010; Thornton 1998; Wrigge 2000; Wrigge 2004; Zhan-fang 2010). Four trials were classified as not randomized (Gajic 2004; Gajic 2005; Lellouche 2012; Wolthuis 2007).

\section{Studies awaiting classification}

Four trials are awaiting classification (Studies awaiting classification table). We were unable to access the report of one trial (Moussa 2003). This study, which included 20 participants, could contain data for ICU and hospital lengths of stay and possibly on pulmonary complications. We reran the search 3 January 2018 and identified three potential new trials (Asida 2015; Haliloglu 2017; Tang 2017). One trial was previously included as ongoing trial and has now been published (Asida 2015). Asida 2015 contains data on length of hospital stay. This trial will be evaluated at the next review update. The two other trials were published between May 2017 and January 2018 (Haliloglu 2017; Tang 2017). They do not contain any outcomes of interest to this review. They will also be formally evaluated at the next review update.

\section{Ongoing studies}

We found three ongoing RCTs fitting our inclusion criteria (Characteristics of ongoing studies table). One study is collecting data on pulmonary complications (including pneumonia and need for ventilatory support), ICU and hospital lengths of stay, and 30-day mortality in participants undergoing major abdominal surgery (ACTRN12614000790640). One trial is collecting data on postoperative mortality in participants undergoing surgery of four hours' duration or more (NCT01003730). One trial is collecting data on pneumonia in adults with a high BMI undergoing laparoscopic surgery (NCT03157479).

\section{Risk of bias in included studies}

The risk of bias of the included studies is shown in the Characteristics of included studies table and Figure 2. Figure 3 summarizes the percentage of studies for which we judged each 
item evaluated as at low, high or unclear risk of bias. Futier 2013, the largest trial available, which included 400 participants, and Memtsoudis 2012 were the studies with the lowest risk of bias. For Futier 2013, potential financial conflict of interest was mentioned (consultant fees and travel expenses for some of the authors), however we do not think that this has affected the results because low or high tidal volumes may be administered with any mechanical ventilators currently available on the market. Therefore, we did not judge this potential conflict of interest as a risk of bias. 
Figure 2. Risk of bias summary: review authors' judgements about each risk of bias item for each included study.

\begin{tabular}{|c|c|c|c|c|c|c|c|}
\hline & 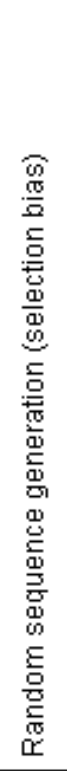 & 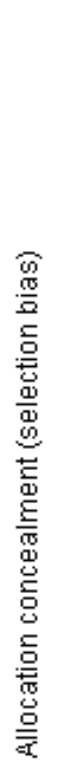 & 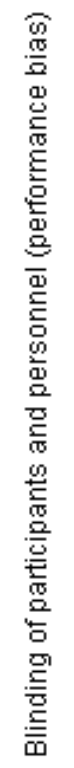 & 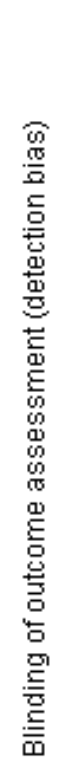 & 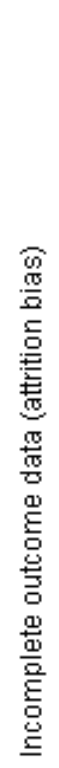 & 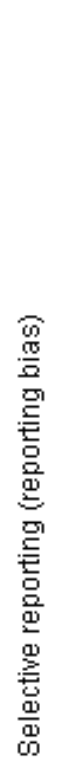 & 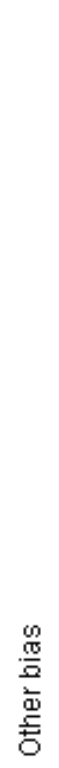 \\
\hline Bates 2015 & + & $?$ & $\odot$ & $?$ & + & $\oplus$ & + \\
\hline Chaney 2000 & $\odot$ & $?$ & $?$ & $?$ & + & 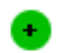 & + \\
\hline Choi 2006 & + & $\odot$ & $?$ & $?$ & + & + & + \\
\hline Chugh 2012 & $\odot$ & $?$ & $?$ & $\odot$ & + & $\odot$ & $\odot$ \\
\hline Fernandez-Bustamante 2014 & $?$ & $?$ & $?$ & $?$ & + & $\oplus$ & + \\
\hline Futier 2013 & + & $\odot$ & $?$ & + & + & $\oplus$ & + \\
\hline Ge 2013 & $\odot$ & ? & $\theta$ & $?$ & + & + & ? \\
\hline Koner 2004 & $?$ & $\odot$ & - & $?$ & + & $\oplus$ & + \\
\hline Kuzkov 2016 & $\odot$ & $\odot$ & $?$ & $\odot$ & + & $\oplus$ & $?$ \\
\hline Memtsoudis 2012 & $\odot$ & $\odot$ & $?$ & $\odot$ & + & $\oplus$ & 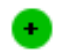 \\
\hline Park 2016a & + & $?$ & $?$ & + & $\odot$ & $\oplus$ & + \\
\hline Sato 2016 & + & + & $?$ & + & + & + & + \\
\hline Shen 2015 & $?$ & $?$ & $?$ & $?$ & + & + & + \\
\hline Soh 2018 & + & + & - & + & + & + & ? \\
\hline Sundar 2011 & + & $?$ & $?$ & + & + & $\oplus$ & $?$ \\
\hline Treschan 2012 & $\odot$ & $\odot$ & $?$ & $\odot$ & + & $\oplus$ & + \\
\hline Weingarten 2010 & + & $?$ & $?$ & $?$ & + & + & $?$ \\
\hline Xiong 2016 & $?$ & $?$ & $?$ & $?$ & + & + & + \\
\hline Zupancich 2005 & $?$ & $?$ & $?$ & $?$ & + & + & + \\
\hline
\end{tabular}


Figure 3. Risk of bias graph: review authors' judgements about each risk of bias item presented as percentages across all included studies.

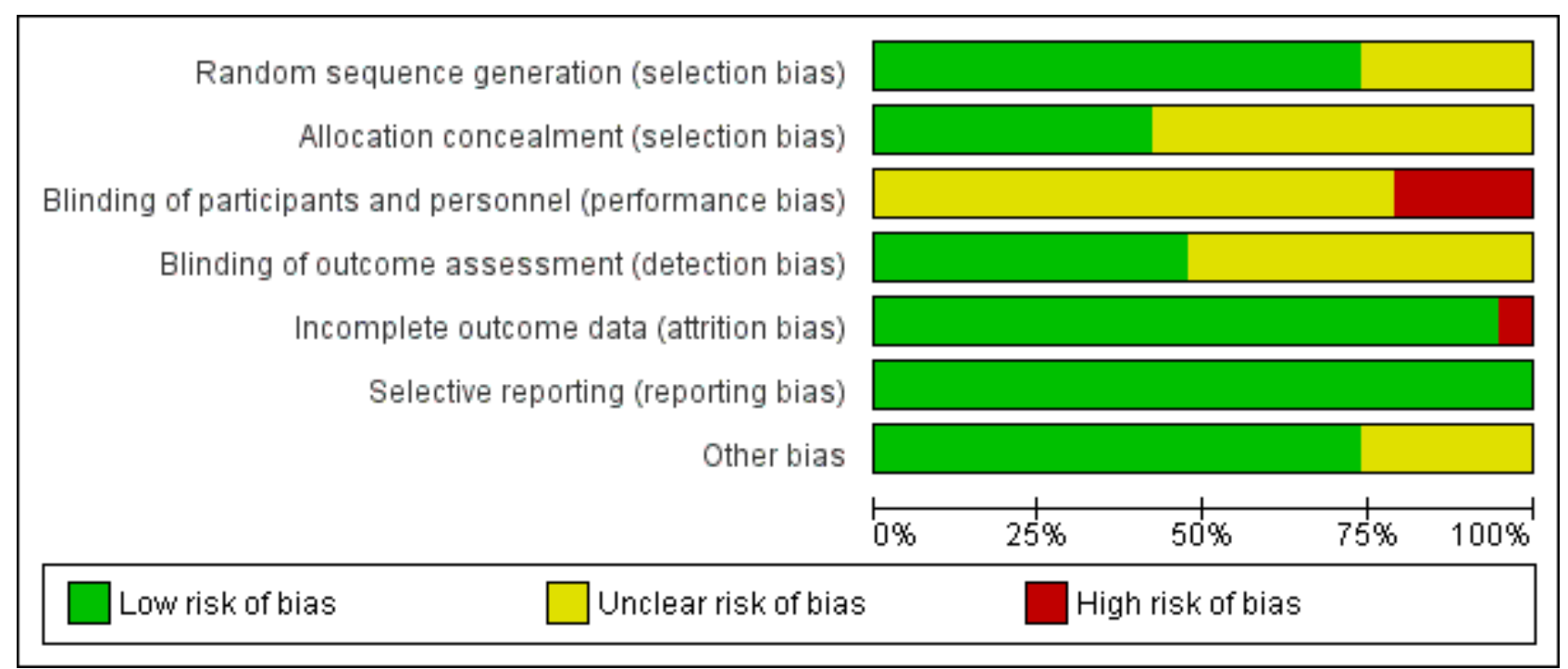

\section{Allocation}

We judged allocation concealment as unclear for more than $50 \%$ of the studies (Figure 3).

\section{Blinding}

For more than $50 \%$ of the studies, there was uncertainty regarding blinding of the outcome assessor to the treatment group allocation (Figure 3). We judged absence of blinding of participants, personnel and outcomes assessors as a high risk or unclear for all studies.

\section{Incomplete outcome data}

We judged most studies as adequate for possible attrition bias (Figure 3).

\section{Selective reporting}

All results mentioned in the methods sections were provided (low risk of reporting bias).

\section{Other potential sources of bias}

We judged more than $50 \%$ of the studies as free of other possible bias (Figure 3). We judged four studies as unclear for this item because of an imbalance in the characteristics of the groups. For Kuzkov 2016, smoking was significantly lower in the high tidal volume group $(P=0.26)$. For Soh 2018 , participants in the low tidal volume group were significantly older than those in the high tidal volume group. For Sundar 2011, the incidence of postoperative complete heart block was higher in the high volume group. For Weingarten 2010, there was a higher proportion of participants with coronary artery disease in the low volume group. Ge 2013 was also judged as unclear for other bias by the the two Chinese reviewers who helped us with this trial. Some outcome definitions were unclear for Ge 2013 (pneumonia).

Overall, we considered the quality of the included trials sufficient to allow us to draw valid conclusions.

\section{Effects of interventions}

See: Summary of findings for the main comparison Low tidal volume compared to high tidal volume for surgery

\section{Primary outcomes}

\section{Mortality}

Twelve studies including 1207 participants reported data for mortality within seven days (Koner 2004), during hospital stay (Bates 2015; Chaney 2000; Choi 2006; Chugh 2012; Treschan 2012; Weingarten 2010; Zupancich 2005), within 28 days (Kuzkov 2016; Sundar 2011), or within 30 days (Futier 2013; Shen 2015). We did not find a difference in mortality between low and high tidal volume groups (RR $0.80,95 \% \mathrm{Cl} 0.42$ to $1.53 ; \mathrm{I}^{2}=0 \%$; Analysis 1.1 ). Egger's regression intercept showed no evidence of small-study effect. The impact of asymmetry in the funnel plot led to a trim and fill estimate of RR 0.81 (95\% Cl 0.42 to 1.57; Figure 4). Based on a basal rate of mortality of $3.0 \%$, such as found in the control groups of the studies included here (Bates 2015; Chaney 2000; Choi 2006; Chugh 2012; Futier 2013; Koner 2004; Kuzkov 2016; Shen 2015; Sundar 2011; Treschan 2012; Weingarten 2010; Zupancich 2005), 32,948 participants (16,474 per group) would be required in a large trial to eliminate a $15 \%$ difference ( $\alpha=0.05 ; \beta=0.2 ; 1$-sided test). 
Figure 4. Mortality. Duval and Tweedie's trim and fill analysis. Actual results displayed in blue. Results corrected for the possibility of a publication bias displayed in red. The impact of asymmetry in the funnel plot led to a trim and fill estimate that would not change the conclusion, that is, there would still not be a difference for mortality between the two interventions (red lozenge).

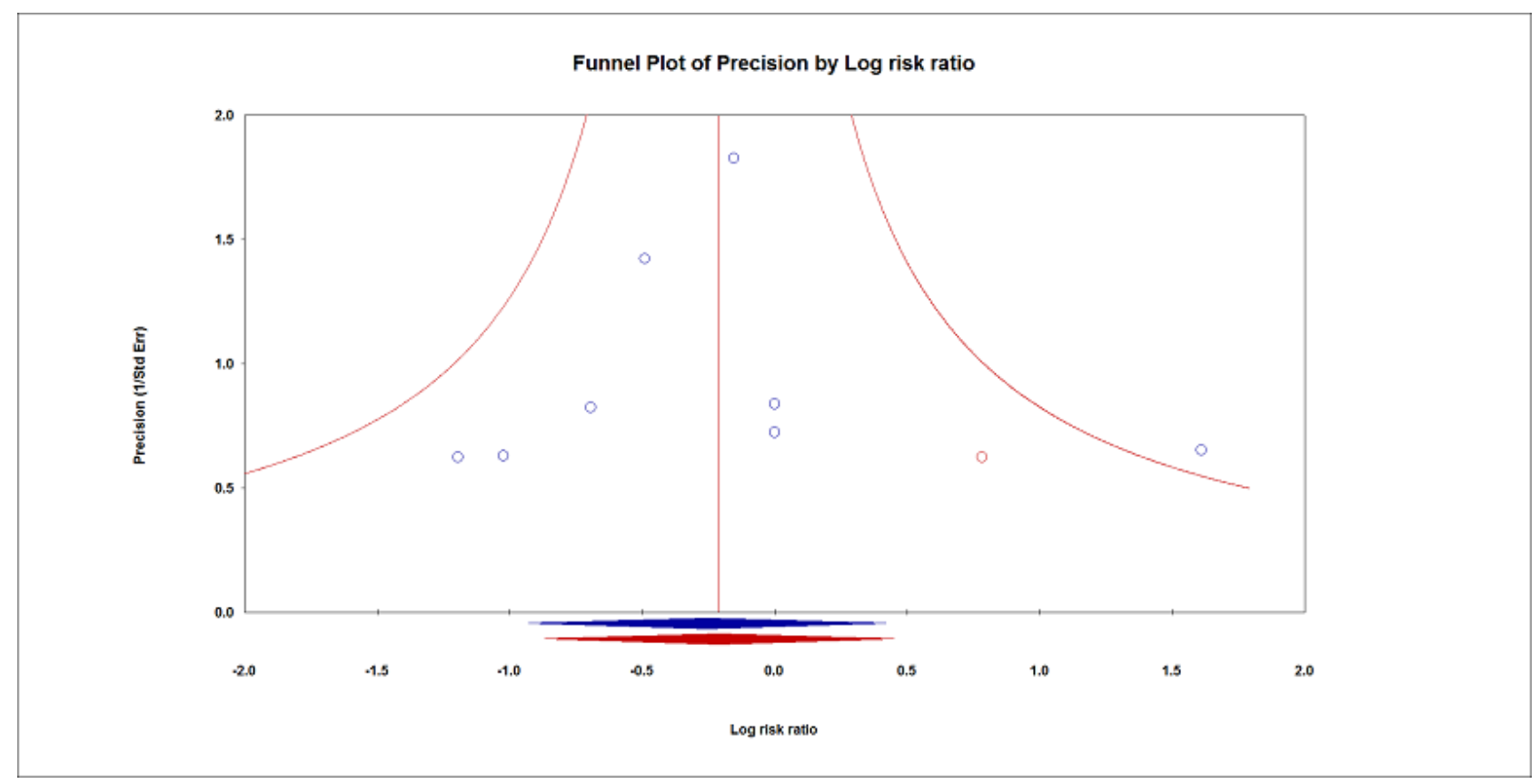

For mortality, we downgraded the level of evidence by one level due to the risk of bias because there was uncertainty around allocation concealment in more than $50 \%$ of the studies. There was no heterogeneity $(12=0 \%)$. We used direct comparisons only and this is not a surrogate marker. We downgraded by one level for imprecision because the optimum information size was not achieved. Correcting for the possibility of publication bias would not change the conclusion (Figure 4). We rated the quality of the evidence as low (Summary of findings for the main comparison).

\section{Secondary outcomes}

\section{Pneumonia}

Based on seven studies, which included 778 participants undergoing abdominal surgery (Futier 2013; Kuzkov 2016; Park 2016a; Treschan 2012; Weingarten 2010), or spinal surgery (Ge 2013; Soh 2018), we found a difference in the risk of postoperative pneumonia between the two groups in favour of low tidal volume (RR $0.45,95 \% \mathrm{Cl} 0.25$ to $0.82 ; 1^{2}=0 \%$; Analysis 1.2 ). Only two trials provided a clear definition (Table 1) (Futier 2013; Shen 2015). Egger's regression intercept showed no evidence of a small-study effect. The impact of asymmetry in the funnel plot leads to a trim and fill estimate of RR 0.47 ( $95 \% \mathrm{Cl} 0.26$ to 0.85 ; Figure 5). Based on a basal rate of $8.5 \%$, the NNTB to obtain one more beneficial effect was 24 (95\% Cl 16 to 160). In a large trial, 3866 (1933 per group) participants would be required to eliminate a $25 \%$ difference ( $\alpha=$ $0.05 ; \beta=0.2 ; 1$-sided test). 
Figure 5. Pneumonia. Duval and Tweedie's trim and fill analysis. Actual results displayed in blue. Results corrected for the possibility of a publication bias displayed in red. The impact of asymmetry in the funnel plot led to a trim and fill estimate that would not change the conclusion, that is, low tidal volumes would still decrease the incidence of pneumonia (red lozenge).

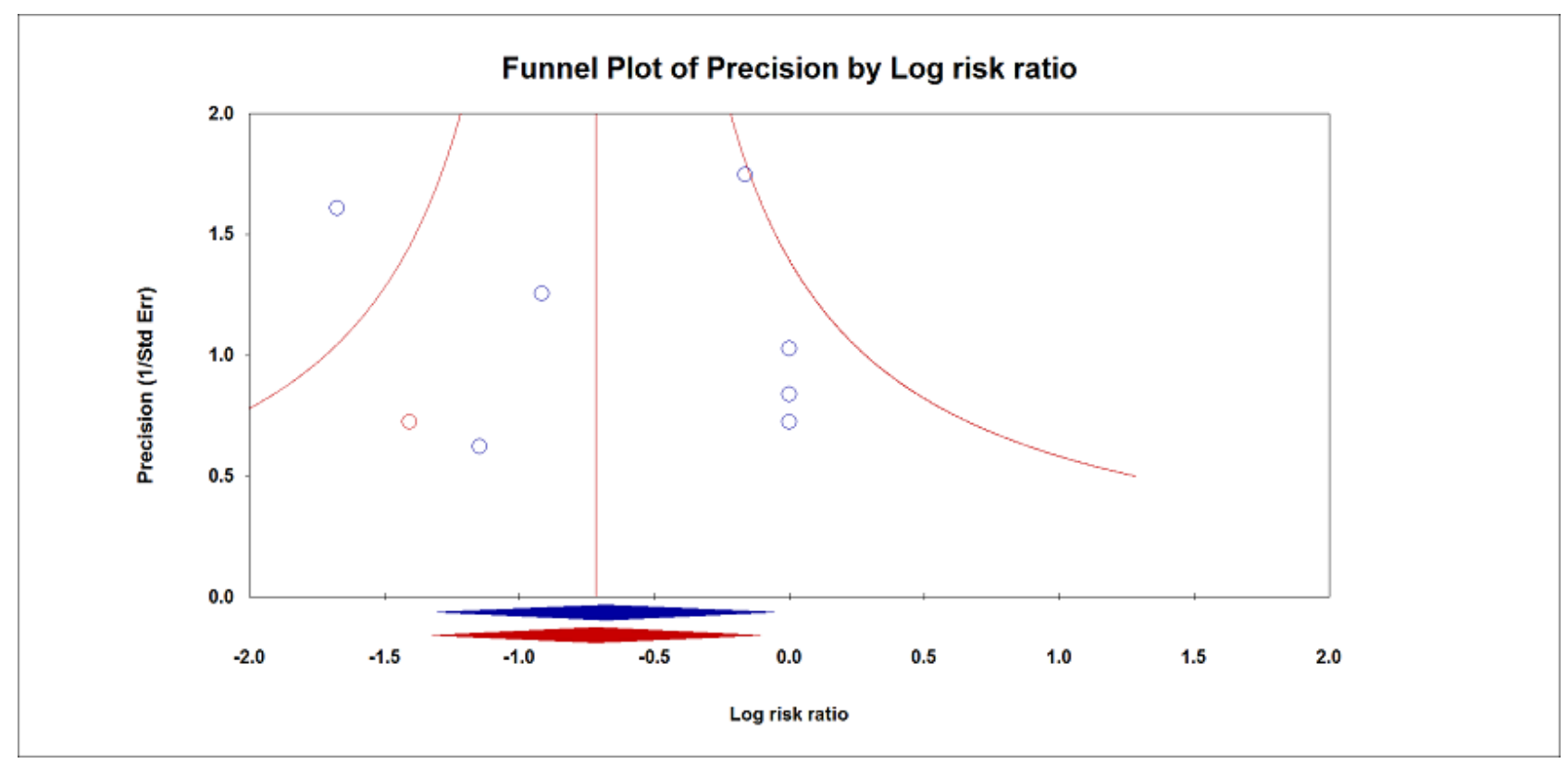

For pneumonia, we did not downgrade for risk of bias because allocation concealment and blinding of the outcome assessor were adequate for more than $50 \%$ of the studies. There was no heterogeneity $\left(1^{2}=0 \%\right)$. We downgraded by one level for imprecision because the optimum information size was not achieved. Correcting for the possibility of publication bias would not change the conclusion (Figure 5). We rated the quality of the evidence as moderate (Summary of findings for the main comparison).

\section{Need for postoperative non-invasive ventilation}

Three studies including 506 participants reported need for postoperative non-invasive ventilation between discharge from the postoperative care unit and seven days after the surgery (Fernandez-Bustamante 2014; Futier 2013; Soh 2018). The RR was 0.31 (95\% Cl 0.15 to 0.64; Analysis 1.3). Criteria for the use of noninvasive ventilation were not defined (Table 2). Based on a basal rate of $11.4 \%$, the NNTB to obtain one more beneficial effect was 13 (95\% Cl 11 to 24$)$. In a large trial, 2734 (1367 per group) participants would be required to eliminate a $25 \%$ difference ( $\alpha=0.05 ; \beta=0.2$; 1 -sided test).

For non-invasive ventilatory support, we did not downgrade for risk of bias because allocation concealment and blinding of the outcome assessor were adequate for more than $50 \%$ of the studies. Heterogeneity and publication bias could not be assessed. We also downgraded the quality of evidence by one level for imprecision based since the optimum information size was not achieved. We rated the quality of the evidence as moderate (Summary of findings for the main comparison).

\section{Need for postoperative invasive ventilation}

Eleven studies, including 957 participants, found low tidal volumes during surgery decreased the need for postoperative invasive ventilatory support (RR $0.33,95 \% \mathrm{Cl} 0.14$ to $0.77 ; \mathrm{I}^{2}=0 \%$; Analysis 1.4) (Chaney 2000; Choi 2006; Fernandez-Bustamante 2014; Futier 2013; Koner 2004; Memtsoudis 2012; Park 2016a; Sato 2016; Soh 2018; Sundar 2011; Treschan 2012). Egger's regression intercept showed no evidence of small-study effect. Duval and Tweedie's trim and fill analysis showed no evidence of publication bias. Based on a basal rate of $3.9 \%$, the NNTB would be 39 (95\% Cl 30 to 166). In a large trial, 8574 (4287 per group) participants would be required to eliminate a $25 \%$ difference ( $\alpha=0.05 ; \beta=0.2 ; 1$-sided test).

For invasive ventilatory support, we did not downgrade for risk of bias because allocation concealment and blinding of the outcome assessor were adequate for more than $50 \%$ of the studies. There was no heterogeneity $(12=0 \%)$ or evidence of publication bias. We downgraded the quality of evidence by one level for imprecision since optimum information size was not achieved. We rated the quality of the evidence as moderate (Summary of findings for the main comparison).

\section{Intensive care unit length of stay}

Based on five studies, which included 898 participants, we found no difference in the ICU length of stay (SMD -0.06 days, $95 \% \mathrm{Cl}-$ 0.22 to $0.10 ; I^{2}=33 \%$; random-effects model; Analysis 1.5) (Bates 2015; Futier 2013; Shen 2015; Sundar 2011; Treschan 2012). Egger's regression intercept showed no evidence of a small-study effect. Duval and Tweedie's trim and fill analysis showed no evidence of publication bias. The effect size was inversely correlated with the volume administered in the low volume groups (Figure 6; P $=0.02$; i.e. the lower the tidal volume, the greater the benefit). Values entered for the meta-regression were: volume of $6.500 \mathrm{~mL} /$ 
$\mathrm{kg}$ (actual volume delivered) and SMD -0.015 days $(95 \% \mathrm{Cl}-0.362$ to 0.331 ) for Bates 2015, volume of $6.400 \mathrm{~mL} / \mathrm{kg}$ (actual volume delivered) and SMD -0.055 days $(95 \% \mathrm{Cl}-0.251$ to 0.141$)$ for Futier 2013 , volume of $6.020 \mathrm{~mL} / \mathrm{kg}$ (actual volume delivered $364.2 \mathrm{~mL}$ and mean weight predicted body weight of the low volume group 60.5 $\mathrm{kg}$ ) and SMD -0.344 days ( $95 \% \mathrm{Cl}-0.704$ to 0.017 ) for Shen 2015 , volume $6.200 \mathrm{~mL} / \mathrm{kg}$ (postintubation) and SMD -0.154 days $(95 \% \mathrm{Cl}$ -0.475 to 0.168 ) for Sundar 2011, and volume $6.700 \mathrm{~mL} / \mathrm{kg}$ (actual volume delivered) and SMD 0.302 days $(95 \% \mathrm{Cl}-0.090$ to 0.694$)$ for Treschan 2012.

\section{Figure 6. Meta-regression. Intensive care unit length of stay versus low tidal volume values. The effect size was} inversely correlated with the tidal volume administered in the low tidal volume groups. $P=0.02$

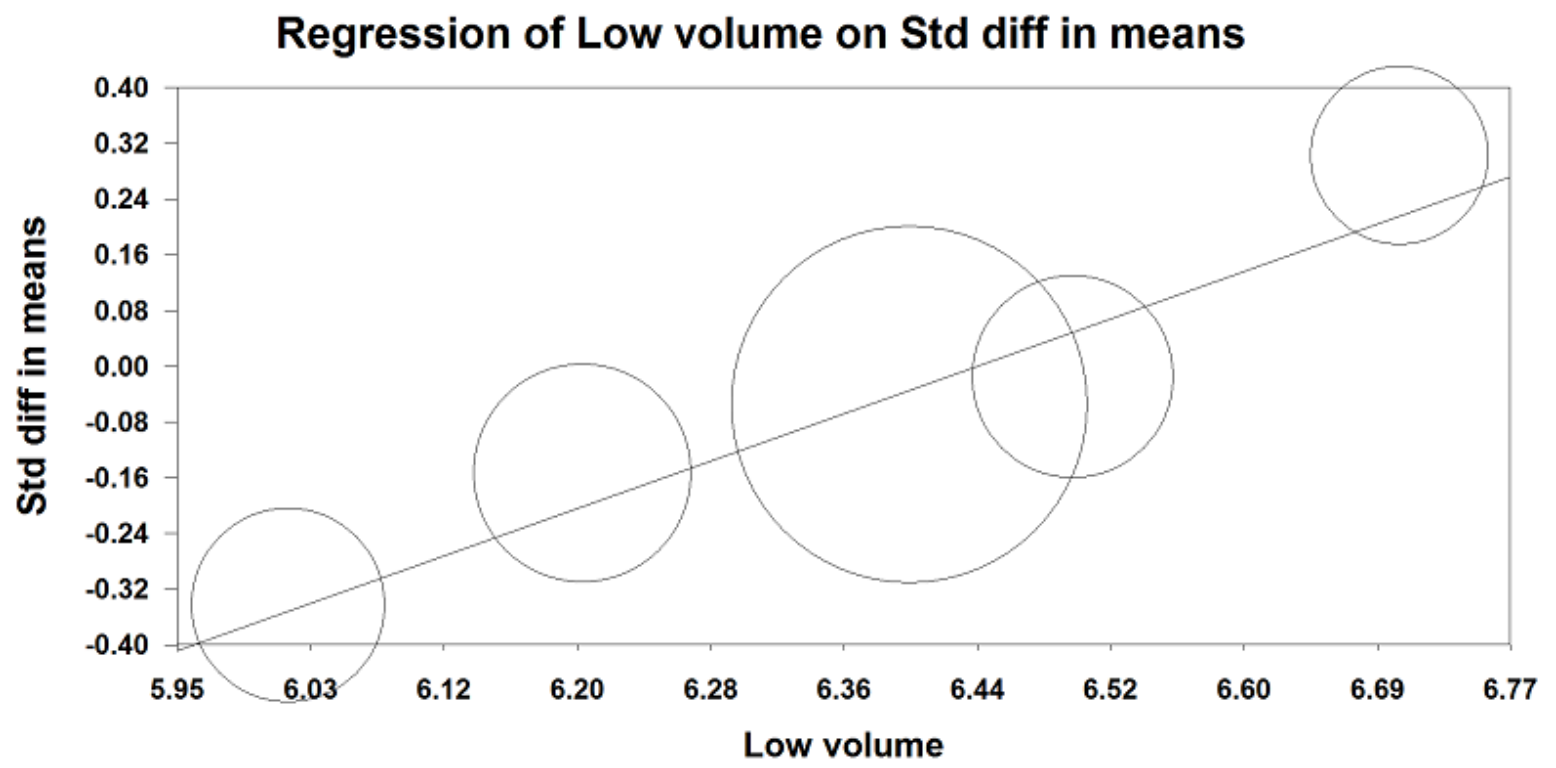

For ICU length of stay, we downgraded the level of evidence by one level because allocation concealment was uncertain in more than $50 \%$ of the studies. We also downgraded by one level for heterogeneity $(12=33 \%)$. We used direct comparisons only and this is not a surrogate marker. We found no evidence of imprecision or publication bias. We also found no evidence for a large effect size or confounding factors justifying upgrading. We did not upgrade for dose-response effect as our meta-regression (Figure 6), contradicts an absence of effect. An effect might have been seen if the limit for qualifying as a low tidal volume had been fixed at a lower value. We rated the quality of the evidence as low (Summary of findings for the main comparison).

\section{Hospital length of stay}

Based on 14 studies, which included 1297 participants, hospital length of stay might have been slightly reduced in the low tidal volume groups (SMD -0.15 days $\left(95 \% \mathrm{Cl}-0.29\right.$ to $0.00 ; \mathrm{I}^{2}=27 \%$; random-effects model; Analysis 1.6) (Bates 2015; Chaney 2000; Chugh 2012; Fernandez-Bustamante 2014; Futier 2013; Koner 2004; Kuzkov 2016; Park 2016a; Sato 2016; Soh 2018; Shen 2015; Sundar 2011; Treschan 2012; Weingarten 2010). Egger's intercept showed no evidence of a small-study effect. Duval and Tweedie's trim and fill analysis showed no evidence of publication bias. Subgrouping showed that hospital length of stay was reduced when PEEP was used for participants of the low tidal group only (SMD -0.23 days, $95 \% \mathrm{Cl}-0.38$ to $\left.-0.08 ; 1^{2}=0 \%\right)$, but not if PEEP was used for all participants (SMD -0.08 days, $95 \% \mathrm{Cl}-0.33$ to $0.18 ; 1^{2}=46 \%$; Analysis 1.6). Low tidal volumes also reduced hospital length of stay when recruitment manoeuvres were used for participants of the low tidal group only (SMD -0.25 days, $95 \% \mathrm{Cl}-0.41$ to $-0.09 ; \mathrm{I}^{2}=$
$0 \%$ ) or were not used (SMD -0.26 days, $95 \% \mathrm{Cl}-0.50$ to $-0.02 ; \mathrm{I}^{2}$ $=14 \%$ ), but not when recruitment manoeuvres were used for all participants (SMD 0.16 days, $95 \% \mathrm{Cl}-0.09$ to $0.40 ; 1^{2}=0 \%$; Analysis 1.7). Based on a trial with a typical standard deviation and low risk of bias (SD in the control group 5.6 days), the difference would be equivalent to 0.8 days or 19.2 hours (Sato 2016).

For hospital length of stay, we downgraded the level of evidence for risk of bias by one level due to uncertainty about allocation concealment for more than $50 \%$ of the included studies. We also downgraded on the basis of heterogeneity $\left(1^{2}=27 \%\right)$. We did not downgrade for indirectness, imprecision or publication bias. We rated the quality of the evidence as low (Summary of findings for the main comparison).

\section{Barotrauma}

Based on five studies, which included 708 participants (Bates 2015; Futier 2013; Park 2016a; Treschan 2012; Weingarten 2010), two of which contain no events (Park 2016a; Weingarten 2010), we found no difference in the risk of pneumothorax (RR $1.77,95 \% \mathrm{Cl} 0.52$ to 5.99; 12 = 0\%; Analysis 1.8). Egger's regression intercept showed no evidence of small-study effect. Duval and Tweedie's trim and fill analysis showed no evidence of publication bias. From a basal rate of $1.1 \%, 29,606$ participants (14,803 per group) would be required to eliminate a difference of $25 \%$ ( $\alpha=0.05 ; \beta=0.2 ; 1$-sided test).

We downgraded the level of evidence due to the risk of bias by one level on the basis of uncertainty about allocation concealment for more than $50 \%$ of the studies. There was no heterogeneity $(12$ $=0 \%$ ), no evidence of publication bias and this is not a surrogate 
marker. We downgraded the quality of evidence by two levels for imprecision on the basis of a very wide $\mathrm{Cls}(95 \% \mathrm{Cl} 0.52$ to 5.99$)$. We judged the quality of the evidence for this outcome as very low (Summary of findings for the main comparison).

We found no other mention of any other type of barotrauma found in any of the 19 included studies (Bates 2015; Chaney 2000; Choi 2006; Chugh 2012; Fernandez-Bustamante 2014; Futier 2013; Ge 2013; Koner 2004; Kuzkov 2016; Memtsoudis 2012; Park 2016a; Sato 2016; Shen 2015; Soh 2018; Sundar 2011; Treschan 2012; Weingarten 2010; Xiong 2016; Zupancich 2005).

\section{DISCUSSION}

\section{Summary of main results}

We did not find a difference in mortality within 30 days after surgery (low-quality evidence); however, the number of participants included in the present meta-analysis represented less than $10 \%$ of the optimum information size for this outcome. From the data available, a $20 \%$ reduction could not be excluded. Therefore, more data will be required before a definitive conclusion can be drawn on the effect of low tidal volume on perioperative death. We found a difference for the risk of pneumonia at zero to seven days after surgery (moderate-quality evidence). Although a clear definition was not provided for all trials, reducing the risk of pneumonia with low tidal volumes make sense as this modality would reduce the need for ventilatory assistance and therefore promote better mobility and reduce VILI. However, this conclusion may change with additional trials.

Low tidal volumes reduce the need for non-invasive and invasive ventilatory support (moderate-quality evidence for both outcomes). However, there were no clear criteria used to apply either of those two treatments (Table 2). Furthermore, no studies used prophylactic non-invasive ventilatory support to help prevent tracheal reintubation and invasive ventilatory support after surgery. Prophylactic non-invasive ventilatory support may help decrease the need for invasive ventilatory support, at least in people at high risk of developing postoperative pulmonary complications after cardiothoracic surgery (Olper 2013).

We did not find a difference for ICU length of stay (low-quality evidence); however, this result contained a moderate amount of heterogeneity. Our data suggested that the effect might have been higher by further reducing the volume of gas insufflated (Figure 6). When we wrote the protocol for this review, the cut-off limit between high and low tidal volume was fixed at $10 \mathrm{~mL} / \mathrm{kg}$ of ideal body weight (Nguyen 2014). This was based on the findings of Levin 2014, a large retrospective trial where low tidal volumes increased mortality rate. In Levin 2014, a tidal volume of $9.7 \mathrm{~mL} /$ $\mathrm{kg}$ of body weight was found as the cut-off point differentiating between low tidal volumes (increasing 30-day mortality rate) and high tidal volumes. Our data seemed to indicate that reducing the tidal volume to $6 \mathrm{~mL} / \mathrm{kg}$ may further increase the benefit of using lower tidal volume (Figure 6). This may have to be further evaluated. We found two studies comparing two different values of "low tidal volumes" (Ding 2016; Severgnini 2013), and evaluating our clinical outcomes after the surgery. Ding 2016 compared a protective strategy including tidal volumes of $6 \mathrm{~mL} / \mathrm{kg}$ coupled with PEEP at $5 \mathrm{cmH}_{2} \mathrm{O}$ and recruitment manoeuvres with tidal volumes of $8 \mathrm{~mL} / \mathrm{kg}$, no PEEP and no recruitment manoeuvres in 60 elderly ASA I or II participants undergoing elective digestive tract surgery of two hours or more. They found that the protective strategy group had lower C-reactive protein and clinical pulmonary infection score at 24 hours after surgery. Severgnini 2013 compared a protective strategy including tidal volumes of $7 \mathrm{~mL} / \mathrm{kg}$, PEEP 10 $\mathrm{cmH}_{2} \mathrm{O}$ and recruitment manoeuvres with tidal volumes of $9 \mathrm{~mL} /$ $\mathrm{kg}$, no PEEP and no recruitment manoeuvres in 56 participants scheduled to undergo elective open abdominal surgery lasting more than two hours. Participants ventilated protectively showed better pulmonary functional tests up to day five; fewer alterations on chest X-ray up to day three; higher arterial oxygenation in air at days one, three and five days after surgery; and lower modified clinical pulmonary infection score at days one and three after surgery. The percentage of participants in hospital at day 28 after surgery was not statistically different between groups ( 7 with low tidal volume versus $15 \%$ with high tidal volume; $\mathrm{P}=0.42$ ).

We found a small difference in hospital length of stay (SMD $0.15,95 \% \mathrm{Cl}-0.29$ to $0.00 ; 1^{2}=27 \%$; equivalent to 0.8 days). However, heterogeneity exploration revealed that the difference was present only when PEEP or recruitment manoeuvres were used for participants of the low tidal volume groups only (PEEP: SMD $-0.23,95 \% \mathrm{Cl}-0.38$ to $-0.08 ; \mathrm{I}^{2}=0 \%$; Analysis 1.6 ; recruitment manoeuvres: SMD $-0.25,95 \% \mathrm{Cl}-0.41$ to $-0.09 ; \mathrm{I}^{2}=0 \%$; Analysis 1.7 ), and not when they were used for all participants. This may indicate that low tidal volume should be used concomitantly with PEEP or recruitment manoeuvres (or both) to obtain a reduction in hospital length of stay or that only the two latter modalities (PEEP and recruitment manoeuvres) have an effect on hospital length of stay or that the effect of PEEP and recruitment manoeuvres on hospital length of stay are much higher than those of low tidal volumes and sufficient to obliterate any further effect of low tidal volumes.

We did not find a difference in the risk of pneumothorax (very low-quality evidence) and this was the only type of barotrauma found by study authors. The number of participants included in the present meta-analysis for this outcome represents less than $1 \%$ of the optimum information size. Therefore, more data will be required for this outcome.

\section{Overall completeness and applicability of evidence}

We found that low tidal volumes during surgery, defined as lower than $10 \mathrm{~mL} / \mathrm{kg}$, reduced the risk of pneumonia and the need for non-invasive and invasive ventilatory support after surgery. A small reduction in hospital length of stay may also have been seen, especially when low tidal volumes were coupled with PEEP and recruitment manoeuvres. We found no deleterious effect of low tidal volumes. Therefore, the results of the present metaanalysis suggested that tidal volumes lower than $10 \mathrm{~mL} / \mathrm{kg}$ should be used preferentially during surgery. The exact tidal volume offering maximal protection may need to be further defined (i.e. decreasing to $6 \mathrm{~mL} / \mathrm{kg}$ may offer better protection). We did not include trials performed on participants undergoing surgery with one-lung ventilation, therefore our conclusion applied only to people undergoing surgery with two-lung mechanical ventilation. The number of participants included in our meta-analysis was too small to eliminate a deleterious effect of small tidal volumes on barotrauma.

\section{Quality of the evidence}

We judged the quality of the evidence as moderate for a reduced risk of pneumonia and for decreased requirement of non-invasive 
and invasive mechanical ventilation after surgery (Summary of findings for the main comparison). We rated the quality of the body of evidence as low for no change in the risk of death, no change in ICU length of stay and a possible small reduction in hospital length of stay. The quality of evidence for absence in the risk of pneumothorax was very low.

\section{Potential biases in the review process}

We considered our search sufficiently extensive and think that we have identified all available relevant studies. Furthermore, by evaluating publication bias with the Duval and Tweedie's trim and fill analysis, we are confident that our estimates for pneumonia, and non-invasive and invasive postoperative ventilatory support requirements are accurate. Also, using the exact $P$ value rather than an estimate of the mean and standard deviation when those values were not available may have prevented us from entering possibly wrong data. The amount of data available was, however, insufficient to eliminate an increase in the risk of barotrauma with the use of small tidal volumes. One small published trial (Moussa 2003; report unavailable), and three ongoing trials (ACTRN12614000790640; NCT01003730; NCT03157479), may shed additional light on outcomes for which it was not possible to obtain a high level of evidence as they will be incorporated in futures updates of this review if their results become available.

\section{Agreements and disagreements with other studies or reviews}

In their retrospective study, Levin and colleagues found that low tidal volumes could increase postoperative mortality (Levin 2014). Although the relatively small number of participants included in the present meta-analysis precluded us for drawing firm conclusions on this, we found no trend towards an increased mortality rate associated with tidal volumes lower than $10 \mathrm{~mL} / \mathrm{kg}$ (Analysis 1.1). It is possible that the results of Levin and colleagues may be attributed to biases introduced by the design of their study (retrospective) or to the use of a relatively high $\mathrm{FiO}_{2}$ (greater than $0.7)$.

While including four RCTs performed in participants undergoing abdominal surgery, Tao colleagues reported that low tidal volumes (defined as $6 \mathrm{~mL} / \mathrm{kg}$ to $8 \mathrm{~mL} / \mathrm{kg}$ ) would decrease in the incidence of atelectasis (odds ratio (OR) $0.36,95 \% \mathrm{Cl} 0.22$ to $0.60 ; \mathrm{P}<0.0001$; $\mathrm{I}^{2}=0 \%$ ) and pulmonary infections (OR $0.30,95 \% \mathrm{Cl} 0.14$ to 0.68 ; $\mathrm{P}$ $=0.004 ; I^{2}=20 \%$ ) (Tao 2014). Other meta-analyses evaluating the effects of low tidal volumes have included non-RCTs (Serpa Neto 2012; Serpa Neto 2015a), or participants with one-lung ventilation (Gu 2015; Park 2016b; Serpa Neto 2015b).

\section{AUTHORS' CONCLUSIONS}

\section{Implications for practice}

There is moderate-quality evidence that low tidal volumes during surgery decrease the risk of pneumonia, and the need for postoperative non-invasive and invasive ventilatory support. We found no evidence for a detrimental effect of routine use of low intraoperative volumes but number of participants included was insufficient to allow us to draw definitive conclusion on possible detrimental effects of using low tidal volumes. The four studies in the Studies awaiting classification table may alter the conclusions of the review once assessed.

\section{Implications for research}

More data are required on a possible increased risk of barotrauma (pneumothorax) with the use of low tidal volumes. Because this outcome requires a very high number of participants, something that would very difficult to obtain from randomized controlled trials, large retrospective well conducted studies may prove useful for this purpose. Further research on the exact tidal volume offering maximal protection may also prove useful.

\section{ACKNOWLEDGEMENTS}

We would like to thank Javier Eslava-Schmalbach (Content Editor); Cathal Walsh (Statistical Editor); Rajesh M Shetty, Rodrigo Cavallazzi and Martin R Lessard (Peer Reviewers); Patricia Tong (Consumer Referee); and Harald Herkner (Sign-off Editor); for their help and editorial advice during the preparation of this updated systematic review.

We thank Karen Hovhannisyan who designed the search strategy, and Janne Vendt who updated the search for us. We also thank the University of Montreal and University of Quebec in Abitibi-Temiscamingue, University of Sherbrooke, Laval University and University of Pennsylvania for granting access to electronic databases and medical journals.

We would also like to thank Jane Cracknell (Managing Editor), Rodrigo Cavallazzi (Content Editor), Marialena Trivella (Statistical Editor) and Samir Jaber and Martin R Lessard (Peer Reviewers) for their help and editorial advice during the preparation of the protocol (Nguyen 2014).

We would like to thank Jane Cracknell (Managing Editor), Rodrigo Cavallazzi (Content Editor), Cathal Walsh (Statistical Editor), Andrew $T$ Jones and Samir Jaber (Peer Reviewers), Patricia Tong (Consumer Referee) and Jenny Bellorini (Copy Editor) for their help and editorial advice during the preparation of the first version of this systematic review (Guay 2015).

We are also in to debt to Mina Nishimori, Jiang Jia, Yuhua-Gao, Min Su, Liu Yidan, Guo Hai, Shuming Pan and Xueyin Shi for handling the Japanese and Chinese studies and to Jiang Jia for translation of two Chinese studies (Shen 2015; Xiong 2016).

We thank Dat Nhut Nguyen who participated in the review up to 28 May 2015. 


\section{REFERE N CES}

\section{References to studies included in this review}

Bates 2015 \{published data only\}

Bates DM, Fernandes TM, Duwe BV, King BO, Banks DA, Test VJ, et al. Efficacy of a low-tidal volume ventilation strategy to prevent reperfusion lung injury after pulmonary thromboendarterectomy. Annals of the American Thoracic Society 2015;12(10):1520-7. [PUBMED: 26241077]

\section{Chaney 2000 \{published data only\}}

Chaney MA, Nikolov MP, Blakeman BP, Bakhos M. Protective ventilation attenuates postoperative pulmonary dysfunction in patients undergoing cardiopulmonary bypass. Journal of Cardiothoracic and Vascular Anesthesia 2000;14(5):514-8. [PUBMED: 11052430]

\section{Choi 2006 \{published data only\}}

* Choi G, Wolthuis EK, Bresser P, Levi M, van der Poll T, Dzoljic M, et al. Mechanical ventilation with lower tidal volumes and positive end-expiratory pressure prevents alveolar coagulation in patients without lung injury. Anesthesiology 2006;105(4):689-95. [PUBMED: 17006066]

Determann RM, Wolthuis EK, Choi G, Bresser P, Bernard A, Lutter R, et al. Lung epithelial injury markers are not influenced by use of lower tidal volumes during elective surgery in patients without preexisting lung injury. American Journal of Physiology. Lung Cellular and Molecular Physiology 2008;294(2):344-50. [PUBMED: 18083770]

Wolthuis EK, Choi G, Dessing MC, Bresser P, Lutter R, Dzoljic M, et al. Mechanical ventilation with lower tidal volumes and positive end-expiratory pressure prevents pulmonary inflammation in patients without preexisting lung injury. Anaesthesiology 2008;108(1):46-54. [PUBMED: 18156881]

\section{Chugh 2012 \{published data only\}}

* Chugh V, Tyagi A, Das S, Sethi AK. Intraoperative ventilation with lowered tidal volumes in patients of perforation peritonitis: effect on postoperative organ dysfunction and systemic inflammatory mediators. www.asaabstracts.com 2012; Vol. Respiration:A1138. [A1138]

\section{Fernandez-Bustamante 2014 \{published data only\}}

Fernandez-Bustamante A, Klawitter J, Repine JE, Agazio A, Janocha AJ, Shah C, et al. Early effect of tidal volume on lung injury biomarkers in surgical patients with healthy lungs. Anesthesiology 2014;121(3):469-81. [PUBMED: 24809976]

\section{Futier 2013 \{published data only\}}

* Futier E, Constantin JM, Paugam-Burtz C, Pascal J, Eurin M, Neuschwander A, et al. A trial of intraoperative low-tidalvolume ventilation in abdominal surgery. New England Journal of Medicine 2013;369(5):428-37. [PUBMED: 23902482]

Jabaudon M, Blondonnet R, Roszyk L, Bazin JE, Pereira B, Sapin V, et al. Influence of intraoperative lung-protective ventilation on lung epithelial marker Srage, the soluble form of the receptor for advanced glycation end-products, in patients without preexisting lung injury. American Journal of Respiratory and Critical Care Medicine. 2015; Vol. 191:A1194.

Jabaudon M, Futier E, Roszyk L, Sapin V, Pereira B, Constantin JM. Association between intraoperative ventilator settings and plasma levels of soluble receptor for advanced glycation end-products in patients without pre-existing lung injury. Respirology 2015;20(7):1131-8. [PUBMED: 26122046]

Neuschwander A, Futier E, Jaber S, Pereira B, Eurin M, Marret E, et al. The effects of intraoperative lung protective ventilation with positive end-expiratory pressure on blood loss during hepatic resection surgery: a secondary analysis of data from a published randomised control trial (IMPROVE). European Journal of Anaesthesiology 2016;33(4):292-8. [PUBMED: 26716865 ]

\section{Ge 2013 \{published data only\}}

Ge Y, Yuan L, Jiang X, Wang X, Xu R, Ma W. Effect of lung protection mechanical ventilation on respiratory function in the elderly undergoing spinal fusion. Zhong Nan da Xue Xue Bao. Yi Xue Ban [Journal of Central South University. Medical Sciences] 2013;38(1):81-5. [PUBMED: 23406861]

\section{Koner 2004 \{published data only\}}

Koner O, Celebi S, Balci H, Cetin G, Karaoglu K, Cakar N. Effects of protective and conventional mechanical ventilation on pulmonary function and systemic cytokine release after cardiopulmonary bypass. Intensive Care Medicine 2004;30(4):620-6. [PUBMED: 14722635]

\section{Kuzkov 2016 \{published data only\}}

Kuzkov VV, Rodionova LN, Ilyina YY, Ushakov AA, Sokolova MM, Fot $\mathrm{EV}$, et al. Protective ventilation improves gas exchange, reduces incidence of atelectases, and affects metabolic response in major pancreatoduodenal surgery. Frontiers in Medicine 2016;3:66. [PUBMED: 27999775]

\section{Memtsoudis 2012 \{published data only\}}

Memtsoudis SG, Bombardieri AM, Ma Y, Girardi FP. The effect of low versus high tidal volume ventilation on inflammatory markers in healthy individuals undergoing posterior spine fusion in the prone position: a randomized controlled trial. Journal of Clinical Anaesthesia 2012;24(4):263-9. [PUBMED: 22001758]

\section{Park 2016a \{published data only\}}

Park SJ, Kim BG, Oh AH, Han SH, Han HS, Ryu JH. Effects of intraoperative protective lung ventilation on postoperative pulmonary complications in patients with laparoscopic surgery: prospective, randomized and controlled trial. Surgical Endoscopy 2016;30(10):4598-606. [PUBMED: 26895920]

\section{Sato 2016 \{published data only\}}

Sato H, Nakamura K, Baba Y, Terada S, Goto T, Kurahashi K. Low tidal volume ventilation with low PEEP during surgery may induce lung inflammation. BioMed Central Anesthesiology 2016;16(1):47. [PUBMED: 27473050] 


\section{Shen 2015 \{published data only\}}

Shen ZJ, Dong R. Value of protective mechanical ventilation for alleviating symptoms of general anesthesia patients with high risk of postoperative pulmonary complications. Journal of Shanghai Jiaotong University (Medical Science) 2015;35(11):1632-5.

\section{Soh 2018 \{published data only\}}

Soh S, Shim JK, Ha Y, Kim YS, Lee H, Kwak YL. Ventilation with high or low tidal volume with PEEP does not influence lung function after spinal surgery in prone position: a randomized controlled trial. Journal of Neurosurgical Anesthesiology 2018;30(3):237-45. [PUBMED: 28338504]

\section{Sundar 2011 \{published data only\}}

Sundar S, Novack V, Jervis K, Bender SP, Lerner A, Panzica P, et al. Influence of low tidal volume ventilation on time to extubation in cardiac surgical patients. Anesthesiology 2011;114(5):1102-10. [PUBMED: 21430518]

\section{Treschan 2012 \{published data only\}}

Treschan TA, Kaisers W, Schaefer MS, Bastin B, Schmalz U, Wania $V$, et al. Ventilation with low tidal volumes during upper abdominal surgery does not improve postoperative lung function. British Journal of Anaesthesia 2012;109(2):263-71. [PUBMED: 22661750]

\section{Weingarten 2010 \{published data only\}}

Weingarten TN, Whalen FX, Warner DO, Gajic O, Schears GJ, Snyder MR, et al. Comparison of two ventilatory strategies in elderly patients undergoing major abdominal surgery. British Journal of Anaesthesia 2010;104(1):16-22. [PUBMED: 19933173]

\section{Xiong 2016 \{published data only\}}

Xiong W, Chen P, Gao J, Yuan R. Lung protective ventilation in elderly patients undergoing spinal operation in the prone position: a randomized controlled trial. Nan Fang Yi Ke da Xue Xue Bao [Journal of Southern Medical University] 2016;36(2):215-9. [PUBMED: 26922019]

\section{Zupancich 2005 \{published data only\}}

Zupancich E, Paparella D, Turani F, Munch C, Rossi A, Massaccesi $S$, et al. Mechanical ventilation affects inflammatory mediators in patients undergoing cardiopulmonary bypass for cardiac surgery: a randomized clinical trial. Journal of Thoracic and Cardiovascular Surgery 2005;130(2):378-83. [PUBMED: 16077402]

\section{References to studies excluded from this review}

\section{Akca 2013 \{published data only\}}

Akca O, Kurz A, Fleischmann E, Buggy D, Herbst F, Stocchi L, et al. Hypercapnia and surgical site infection: a randomized trial. British Journal of Anaesthesia 2013;111(5):759-67. [PUBMED: 23887247]

\section{Arora 2017 \{published data only\}}

Arora V, Tyagi A, Kumar S, Kakkar A, Das S. Intraoperative low tidal volume ventilation strategy has no benefits during laparoscopic cholecystectomy. Journal of Anaesthesiology, Clinical Pharmacology 2017;33(1):57-63. [PUBMED: 28413273]

Baki 2014 \{published data only\}

Baki ED, Kokulu S, Bal A, Ela Y, Sivaci RG, Yoldas M, et al. Evaluation of low tidal volume with positive end-expiratory pressure application effects on arterial blood gases during laparoscopic surgery. Journal of the Chinese Medical Association 2014;77(7):374-8. [PUBMED: 24950920]

Blum 2013 \{published data only\}

Blum JM, Stentz MJ, Maile MD, Jewell E, Raghavendran K, Engoren $\mathrm{M}$, et al. Automated alerting and recommendations for the management of patients with preexisting hypoxia and potential acute lung injury: a pilot study. Anesthesiology 2013;119(2):295-302. [PUBMED: 23681144]

\section{Cai 2007 \{published data only\}}

Cai H, Gong H, Zhang L, Wang Y, Tian Y. Effect of low tidal volume ventilation on atelectasis in patients during general anaesthesia: a computed tomographic scan. Journal of Clinical Anaesthesia 2007;19(2):125-9. [PUBMED: 17379125]

\section{Clarke 1998 \{published data only\}}

Clarke JP, Schuitemaker MN, Sleigh JW. The effect of intraoperative ventilation strategies on perioperative atelectasis. Anaesthesia and Intensive Care 1998;26(3):262-6. [PUBMED: 9619219]

\section{Cui 2015 \{published data only\}}

Cui Y, Pi X, Wang C, Liu S, Gong Y, Wang Y, et al. Effects of different ventilation strategies on exhaled nitric oxide in geriatric abdominal surgery. Journal of Breath Research 2015;9(1):016006. [PUBMED: 25719610]

\section{Determann 2010 \{published data only\}}

Determann RM, Royakkers A, Wolthuis EK, Vlaar AP, Choi G, Paulus $F$, et al. Ventilation with lower tidal volumes as compared with conventional tidal volumes for patients without acute lung injury: a preventive randomized controlled trial. Critical Care (London, England) 2010;14(1):R1. [DOI: 10.1152/ ajplung.00268.2007; PUBMED: 20055989]

\section{Ding 2016 \{published data only\}}

Ding W, Shen L, Xiang MJ, Yu C, Lu ZJ. Effects of low tidal volume mechanical ventilation and lung recruitment maneuver on early pulmonary infection after abdominal operations in elderly patients. Journal of Shanghai Jiao Tong University (Medical Science) 2016;36(11):1617-21.

\section{Ela 2014 \{published data only\}}

Ela Y, Baki ED, Ates M, Kokulu S, Keles I, Karalar M, et al. Exploring for the safer ventilation method in laparoscopic urologic patients? Conventional or low tidal?. Journal of Laparoendoscopic \& Advanced Surgical Techniques. Part a 2014;24(11):786-90. [PUBMED: 24918629]

\section{Ferrando 2015 \{published data only\}}

Ferrando C, Soro M, Canet J, Unzueta MC, Suarez F, Librero J, et al. Rationale and study design for an individualized perioperative open lung ventilatory strategy (iPROVE): study 
protocol for a randomized controlled trial. Trials 2015;16:193. [PUBMED: 25927183]

\section{Gajic 2004 \{published data only\}}

Gajic O, Dara SI, Mendez JL, Adesanya AO, Festic E, Caples SM, et al. Ventilator-associated lung injury in patients without acute lung injury at the onset of mechanical ventilation. Critical Care Medicine 2004;32(9):1817-24. [PUBMED: 15343007]

\section{Gajic 2005 \{published data only\}}

Gajic O, Frutos-Vivar F, Esteban A, Hubmayr RD, Anzueto A. Ventilator settings as a risk factor for acute respiratory distress syndrome in mechanically ventilated patients. Intensive Care Medicine 2005;31(7):922-6. [PUBMED: 15856172]

\section{Gong 2007 \{published data only\}}

Gong H, Zhang LN, Cai HW, Wang YJ, Hou YH. Effect of different tidal volume ventilations on atelectasis in patients during general anaesthesia by CT scan. Zhong Nan da Xue Xue Bao. Yi Xue Ban [Journal of Central South University. Medical Sciences] 2007;32(5):850-4. [PUBMED: 18007083]

\section{Hosten 2017 \{published data only\}}

Hosten T, Kus A, Gumus E, Yavuz S, Irkil S, Solak M. Comparison of intraoperative volume and pressure-controlled ventilation modes in patients who undergo open heart surgery. Journal of Clinical Monitoring and Computing 2017;31(1):75-84. [PUBMED: 26992377]

\section{Jain 2016 \{published data only\}}

Jain AK. A ventilatory strategy for morbidly obese undergoing laparoscopic surgery - abdominal obesity based approach. Anesthesia and Analgesia 2016;123 (3 Suppl 2):812. [EMBASE: 612648492]

\section{Jiang 2007 \{published data only\}}

Jiang JJ, Yuan HB, Sun PL. Effect of low tidal volume ventilation plus positive end-expiratory pressure on pulmonary oxygenation in septic patients during operation. Academic Journal of Second Military Medical University 2007;28(5):570-2. [DOI: 10.3724/SP.J.1008.2007.00570]

\section{Kaisers 2009 \{published data only\}}

Kaisers W, Wania V, Eisenberger C, Schmitz A, Treschan T. Influence of high versus low tidal volumes on airway pressure in patients with healthy lungs [Abstract]. European Journal of Anaesthesiology 2009;26(Suppl 45):81.

\section{Kanaya 2011 \{published data only\}}

Kanaya A, Satoh D, Kurosawa S. Influence of tidal volume on functional residual capacity during general anaesthesia. Masui. The Japanese Journal of Anesthesiology 2011;60(10):1149-52. [PUBMED: 22111353]

\section{Kang 2014 \{published data only\}}

Kang WS, Kim SH, Woo Chung J. Comparison of pulmonary gas exchange according to intraoperative ventilation modes for mitral valve repair surgery via thoracotomy with onelung ventilation: a randomized controlled trial. Journal of Cardiothoracic and Vascular Anaesthesia 2014;28(4):920-5. [PUBMED: 24480179]
Kim 2012 \{published data only\}

Kim SH, Jung KT, An TH. Effects of tidal volume and PEEP on arterial blood gases and pulmonary mechanics during one-lung ventilation. Journal of Anaesthesia 2012;26(4):568-73. [PUBMED: 22349751]

\section{Kokulu 2015 \{published data only\}}

Kokulu S, Gunay E, Baki ED, Ulasli SS, Yilmazer M, Koca B, et al. Impact of a lung-protective ventilatory strategy on systemic and pulmonary inflammatory responses during laparoscopic surgery: is it really helpful?. Inflammation 2015;38(1):361-7. [PUBMED: 25280837]

Lee 1990 \{published data only\}

Lee PC, Helsmoortel CM, Cohn SM, Fink MP. Are low tidal volumes safe?. Chest 1990;97(2):430-4. [PUBMED: 2288551]

Lellouche 2012 \{published data only\}

Lellouche F, Dionne S, Simard S, Bussieres J, Dagenais F. High tidal volumes in mechanically ventilated patients increase organ dysfunction after cardiac surgery. Anesthesiology 2012;116(5):1072-82. [DOI: 10.1097/ALN.0b013e3182522df5; PUBMED: 22450472]

\section{Lin 2008 \{published data only\}}

Lin WQ, Lu XY, Cao LH, Wen LL, Bai XH, Zhong ZJ. Effects of the lung protective ventilatory strategy on proinflammatory cytokine release during one-lung ventilation. Ai Zheng [Chinese Journal of Cancer] 2008;27(8):870-3. [PUBMED: 18710624]

Liu 2016 \{published data only\}

Liu Y, Lou JS, Mi WD, Yuan WX, Fu Q, Wang M, et al. Pulse pressure variation shows a direct linear correlation with tidal volume in anesthetized healthy patients. BioMed Central Anesthesiology 2016;16:75. [PUBMED: 27609188]

Mascia 2010 \{published data only\}

Mascia L, Pasero D, Slutsky AS, Arguis MJ, Berardino M, Grasso S, et al. Effect of a lung protective strategy for organ donors on eligibility and availability of lungs for transplantation: a randomized controlled trial. JAMA 2010;304(23):2620-7. [PUBMED: 21156950]

\section{Maslow 2013 \{published data only\}}

Maslow AD, Stafford TS, Davignon KR, Ng T. A randomized comparison of different ventilator strategies during thoracotomy for pulmonary resection. Journal of Thoracic and Cardiovascular Surgery 2013;146(1):38-44. [PUBMED: 23380515]

\section{Michelet 2006 \{published data only\}}

Michelet P, D'Journo XB, Roch A, Doddoli C, Marin V, Papazian L, et al. Protective ventilation influences systemic inflammation after esophagectomy: a randomized controlled study. Anesthesiology 2006;105(5):911-9. [PUBMED: 17065884]

Pinheiro 2010 \{published data only\}

Pinheiro de Oliveira R, Hetzel MP, dos Anjos Silva M, Dallegrave D, Friedman G. Mechanical ventilation with high tidal volume induces inflammation in patients without lung disease. Critical Care (London, England) 2010;14(2):R39. [DOI: 10.1186/ cc8919; PUBMED: 20236550] 
Reis Miranda 2005a \{published data only\}

Reis Miranda D, Struijs A, Koetsier P, van Thiel R, Schepp R, Hop W, et al. Open lung ventilation improves functional residual capacity after extubation in cardiac surgery. Critical Care Medicine 2005;33(10):2253-8. [PUBMED: 16215379]

\section{Reis Miranda 2005b \{published data only\}}

Reis Miranda D, Gommers D, Struijs A, Dekker R, Mekel J, Feelders R, et al. Ventilation according to the open lung concept attenuates pulmonary inflammatory response in cardiac surgery. European Journal of Cardio-thoracic Surgery 2005;28(6):889-95. [PUBMED: 16271479]

\section{Satoh 2012 \{published data only\}}

Satoh D, Kurosawa S, Kirino W, Wagatsuma T, Ejima Y, Yoshida A, et al. Impact of changes of positive end-expiratory pressure on functional residual capacity at low tidal volume ventilation during general anaesthesia. Journal of Anaesthesia 2012;26(5):664-9. [PUBMED: 22584817]

\section{Severgnini 2013 \{published data only\}}

Severgnini P, Selmo G, Lanza C, Chiesa A, Frigerio A, Bacuzzi A, et al. Protective mechanical ventilation during general anaesthesia for open abdominal surgery improves postoperative pulmonary function. Anesthesiology 2013;118(6):1307-21. [PUBMED: 23542800]

\section{Shin 2010 \{published data only\}}

Shin HY, Kim SH, Lee YJ, Kim DK. The effect of mechanical ventilation tidal volume during pneumoperitoneum on shoulder pain after a laparoscopic appendectomy. Surgical Endoscopy 2010;24(8):2002-7. [PUBMED: 20135168]

\section{Thornton 1998 \{published data only\}}

Thornton S, Fletcher R, Foster P. Little effect of ventilatory rate and tidal volume on end-expiratory pressure after cardiac surgery. British Journal of Anaesthesia 1998;80(4):553-4. [EMBASE: 28171415]

\section{Tugrul 1998 \{published data only\}}

Tugrul M, Camci E, Yavru A, Turnaoglu S, Karakoca S, Ozkan T, et al. Reducing tidal volume does not affect oxygenation in ASA I-II patients during anaesthesia. Applied Cardiopulmonary Pathophysiology 1998;8(1):29-35. [EMBASE: 29462282]

\section{Tusman 1999 \{published data only\}}

Tusman G, Bohm SH, Vazquez de Anda GF, do Campo JL, Lachmann B. 'Alveolar recruitment strategy' improves arterial oxygenation during general anaesthesia. British Journal of Anaesthesia 1999;82(1):8-13. [PUBMED: 10325828]

\section{Tweed 1991 \{published data only\}}

Tweed WA, Phua WT, Chong KY, Lim E, Lee TL. Large tidal volume ventilation improves pulmonary gas exchange during lower abdominal surgery in Trendelenburg's position. Canadian Journal of Anaesthesia 1991;38(8):989-95. [PUBMED: 1752022]

\section{Visick 1973 \{published data only\}}

Visick WD, Fairley HB, Hickey RF. The effects of tidal volume and end-expiratory pressure on pulmonary gas exchange during anaesthesia. Anesthesiology 1973;39(3):285-90. [PUBMED: 4580631]

\section{Weismann 2010 \{published data only\}}

Weismann D, Maier SKG. Prevention of a breathing trauma with low tidal volume ventilation: results of a randomized, controlled prevention study [Prävention eines beatmungstraumas mit niedrigen tidalvolumina. Ergebnisse einer randomisierten, kontrollierten präventionsstudie]. Medizinische Klinik 2010;105(3):178-9. [EMBASE: 358748244]

\section{Wolthuis 2007 \{published data only\}}

Wolthuis EK, Korevaar JC, Spronk P, Kuiper MA, Dzoljic M, Vroom MB, et al. Feedback and education improve physician compliance in use of lung-protective mechanical ventilation. Intensive Care Medicine 2005;31(4):540-6. [DOI: 10.1007] s00134-005-2581-9; PUBMED: 15731892]

* Wolthuis EK, Veelo DP, Choi G, Determann RM, Korevaar JC, Spronk PE, et al. Mechanical ventilation with lower tidal volumes does not influence the prescription of opioids or sedatives. Critical Care (London, England) 2007;11(4):R77. [DOI: 10.1186/cc5969; PUBMED: 17629900]

\section{Wrigge 2000 \{published data only\}}

Wrigge H, Zinserling J, Stuber F, von Spiegel T, Hering R, Wetegrove $\mathrm{S}$, et al. Effects of mechanical ventilation on release of cytokines into systemic circulation in patients with normal pulmonary function. Anesthesiology 2000;93(6):1413-7. [PUBMED: 11149435]

\section{Wrigge 2004 \{published data only\}}

Wrigge $\mathrm{H}$, Uhlig U, Zinserling J, Behrends-Callsen E, Ottersbach G, Fischer M, et al. The effects of different ventilatory settings on pulmonary and systemic inflammatory responses during major surgery. Anaesthesia and Analgesia 2004;98(3):775-81. [DOI: 10.1213/01.ANE.0000100663.11852.BF; PUBMED: 14980936$]$

\section{Wrigge 2005 \{published data only\}}

Wrigge H, Uhlig U, Baumgarten G, Menzenbach J, Zinserling J, Ernst M, et al. Mechanical ventilation strategies and inflammatory responses to cardiac surgery: a prospective randomized clinical trial. Intensive Care Medicine 2005;31(10):1379-87. [PUBMED: 16132888]

\section{Yang 2011 \{published data only\}}

Yang M, Ahn HJ, Kim K, Kim JA, Yi CA, Kim MJ, et al. Does a protective ventilation strategy reduce the risk of pulmonary complications after lung cancer surgery?: a randomized controlled trial. Chest 2011;139(3):530-7. [PUBMED: 20829341]

\section{Zhan-fang 2010 \{published data only\}}

Zhan-fang LI, Min ZJ, Qing-hua LI, Tian ZY, Cheng LU, Jiang B, et al. The optimal combination of mechanical ventilatory parameters under general anaesthesia in obese patients undergoing laparoscopic surgery. Fudan University Journal of Medical Sciences 2010;37(1):11-5. 


\section{References to studies awaiting assessment}

Asida 2015 \{published data only\}

ACTRN12614000100695. Effect of low tidal volume during general anaesthesia for urological procedures on lung functions. www.anzctr.org.au/Trial/Registration/ TrialReview.aspx?ACTRN=12614000100695 Date first received: 28 January 2014.

* Asida S, Badawy M. Effect of low tidal volume during general anesthesia for urological procedures on lung functions. Egyptian Journal of Anaesthesia 2015;31:127-34. [CENTRAL: 01070550; DOI: 10.1016/j.egja.2015.02.001; EMBASE: 603507596]

Badawy M, Asida S. Effect of low tidal volume during general anesthesia for urological procedures on lung functions. Chest 2015;148:1015A. [CENTRAL: 01163112; DOI: 10.1378/ chest.2275080; EMBASE: 72132873]

Badawy M, Asida S. Effect of low tidal volume during general anesthesia for urological procedures on lung functions. European Respiratory Journal 2015;46:1824. [CENTRAL: 01162393; DOI: 10.1183/13993003; EMBASE: 72105867]

\section{Haliloglu 2017 \{published data only\}}

Haliloglu M, Bilgili B, Ozdemir M, Umuroglu T, Bakan N. Low tidal volume-positive end-expiratory pressure versus high tidal volume-zero positive end-expiratory pressure and postoperative pulmonary functions in robot-assisted laparoscopic radical prostatectomy. Medical Principles and Practice 2017;31:31. [DOI: 10.1159/000484693; PUBMED: 29131002]

\section{Moussa 2003 \{published data only\}}

Moussa SF, El Khlousy M. Clinical and laboratory assessment of protective ventilation versus conventional ventilation in patients undergoing coronary artery bypass surgery. Egyptian Journal of Anaesthesia 2003;19(4):337-43. [CENTRAL: 00474837]

\section{Tang 2017 \{published data only\}}

Tang C, Li J, Lei S, Zhao B, Zhang Z, Huang W, et al. Lungprotective ventilation strategies for relief from ventilatorassociated lung injury in patients undergoing craniotomy: a bicenter randomized, parallel, and controlled trial. Oxidative Medicine and Cellular Longevity 2017;2017:1-12. [CENTRAL: 01394981; DOI: 10.1155/2017/6501248; EMBASE: 617361026; PUBMED: 28757912]

\section{References to ongoing studies}

\section{ACTRN12614000790640 \{published data only\}}

ACTRN12614000790640. A prospective randomised trial of two tidal volume ventilator strategies in patients undergoing major surgery. www.anzctr.org.au/Trial/Registration/ TrialReview.aspx?id=366752\&isReview=true Date first received: 24 July 2014

\section{NCT01003730 \{published data only\}}

NCT01003730. The effects of different ventilator strategies on inflammation and injury in normal lungs. clinicaltrials.gov/ ct2/show/NCT01003730 Date first received: 29 October 2009. [NCT01003730]

\section{NCT03157479 \{published data only\}}

NCT03157479. Intraoperative protective ventilation for obese patients undergoing gynaecological laparoscopic surgery (Inprove4large). clinicaltrials.gov/ct2/show/NCT03157479 Date first received: 17 May 2017. [NCT03157479]

\section{Additional references}

\section{Acute Respiratory Distress Syndrome Network}

Acute Respiratory Distress Syndrome Network, Brower RG, Matthay MA, Morris A, Schoenfeld D, Thompson BT, et al. Ventilation with lower tidal volumes as compared with traditional tidal volumes for acute lung injury and the acute respiratory distress syndrome. New England Journal of Medicine 2000;342(18):1301-8. [PUBMED: 10793162]

\section{Aliverti 2011}

Aliverti A, Kostic P, Lo Mauro A, Andersson-Olerud M, Quaranta M, Pedotti A, et al. Effects of propofol anaesthesia on thoraco-abdominal volume variations during spontaneous breathing and mechanical ventilation. Acta Anaesthesiologica Scandinavica 2011;55(5):588-96. [PUBMED: 21385159]

\section{Barbosa 2014}

Barbosa FT, Castro AA, de Sousa-Rodrigues CF. Positive endexpiratory pressure (PEEP) during anaesthesia for prevention of mortality and postoperative pulmonary complications. Cochrane Database of Systematic Reviews 2014, Issue 6. [DOI: 10.1002/14651858.CD007922.pub3]

\section{Bendixen 1963}

Bendixen HH, Hedley-Whyte J, Laver MB. Impaired oxygenation in surgical patients during general anaesthesia with controlled ventilation. A concept of atelectasis. New England Journal of Medicine 1963;269:991-6. [PUBMED: 14059732]

\section{Borenstein 2009}

Borenstein M, Hedges LV, Higgins PT, Rothstein HR. Publication bias. In: Borenstein M, Hedges LV, Higgins JP, Rothstein HR editor(s). Introduction to Meta-Analysis. 1st Edition. Chichester, UK: Wiley, 2009:277-92.

\section{Brismar 1985}

Brismar B, Hedenstierna G, Lundquist $\mathrm{H}$, Strandberg A, Svensson L, Tokics L. Pulmonary densities during anaesthesia with muscular relaxation - a proposal of atelectasis. Anesthesiology 1985;62(4):422-8. [PUBMED: 3885791]

\section{Deeks 2002}

Deeks JJ. Issues in the selection of a summary statistic for metaanalysis of clinical trials with binary outcomes. Statistics in Medicine 2002;21(11):1575-600. [PUBMED: 12111921]

\section{Duval 2000a}

Duval S, Tweedie R. A simple funnel-plot-based method of testing and adjusting for publication bias in meta-analysis. Biometrics 2000;56(2):455-63. [PUBMED: 10877304]

Intraoperative use of low volume ventilation to decrease postoperative mortality, mechanical ventilation, lengths of stay and lung injury

in adults without acute lung injury (Review)

Copyright (c) 2018 The Cochrane Collaboration. Published by John Wiley \& Sons, Ltd. 


\section{Duval 2000b}

Duval S, Tweedie R. A nonparametric "trim and fill" method accounting for publication bias in meta-analysis. Journal of the American Statistical Association 2000;95(449):89-98.

\section{Edmark 2011}

Edmark L, Auner U, Enlund M, Ostberg E, Hedenstierna G. Oxygen concentration and characteristics of progressive atelectasis formation during anaesthesia. Acta Anaesthesiologica Scandinavica 2011;55(1):75-81. [PUBMED: 21039356]

\section{Eldridge 2004}

Eldridge MW, Dempsey JA, Haverkamp HC, Lovering AT, Hokanson JS. Exercise-induced intrapulmonary arteriovenous shunting in healthy humans. Journal of Applied Physiology 2004;97(3):797-805. [PUBMED: 15107409]

\section{Gu 2015}

Gu WJ, Wang F, Liu JC. Effect of lung-protective ventilation with lower tidal volumes on clinical outcomes among patients undergoing surgery: a meta-analysis of randomized controlled trials. Canadian Medical Association Journal 2015;187(3):E101-9. [DOI: 10.1503/cmaj.141005; PUBMED: 25512653]

\section{Gunnarsson 1991}

Gunnarsson L, Tokics L, Gustavsson H, Hedenstierna G. Influence of age on atelectasis formation and gas exchange impairment during general anaesthesia. British Journal of Anaesthesia 1991;66(4):423-32. [PUBMED: 2025468]

\section{Guyatt 2008}

Guyatt GH, Oxman AD, Vist GE, Kunz R, Falck-Ytter Y, AlonsoCoello $P$, et al. GRADE: an emerging consensus on rating quality of evidence and strength of recommendations. BMJ (Clinical Research Ed.) 2008;336(7650):924-6. [PUBMED: 18436948]

\section{Guyatt 2011}

Guyatt G, Oxman AD, Akl EA, Kunz R, Vist G, Brozek J, et al. GRADE guidelines: 1 . Introduction - GRADE evidence profiles and summary of findings tables. Journal of Clinical Epidemiology 2011;64(4):383-94. [PUBMED: 21195583]

\section{Higgins 2003}

Higgins JP, Thompson SG, Deeks JJ, Altman DG. Measuring inconsistency in meta-analyses. BMJ (Clinical Research Ed.) 2003;327(7414):557-60. [PUBMED: 12958120]

\section{Higgins 2011}

Higgins JP, Green S, editor(s). Cochrane Handbook for Systematic Reviews of Interventions Version 5.1.0 (updated March 2011). The Cochrane Collaboration, 2011. Available from handbook.cochrane.org.

\section{Levin 2014}

Levin MA, McCormick PJ, Lin HM, Hosseinian L, Fischer GW. Low intraoperative tidal volume ventilation with minimal PEEP is associated with increased mortality. British Journal of Anaesthesia 2014;113(1):97-108. [PUBMED: 24623057]

\section{Olper 2013}

Olper L, Corbetta D, Cabrini L, Landoni G, Zangrillo A. Effects of non-invasive ventilation on reintubation rate: a systematic review and meta-analysis of randomised studies of patients undergoing cardiothoracic surgery. Critical Care and Resuscitation 2013;15(3):220-7. [PUBMED: 23944209]

\section{Pace 2011}

Pace NL. Research methods for meta-analyses. Best Practice \& Research. Clinical Anaesthesiology 2011;25(4):523-33. [PUBMED: 22099918]

\section{Park 2016b}

Park SH. Perioperative lung-protective ventilation strategy reduces postoperative pulmonary complications in patients undergoing thoracic and major abdominal surgery. Korean Journal of Anesthesiology 2016;69(1):3-7. [DOI: 10.4097/ kjae.2016.69.1.3; PUBMED: 26885294]

\section{Petersson 2010}

Petersson J, Ax M, Frey J, Sanchez-Crespo A, Lindahl SG, Mure M. Positive end-expiratory pressure redistributes regional blood flow and ventilation differently in supine and prone humans. Anesthesiology 2010;113(6):1361-9. [PUBMED: 21068656]

\section{Petrucci 2013}

Petrucci N, De Feo C. Lung protective ventilation strategy for the acute respiratory distress syndrome. Cochrane Database of Systematic Reviews 2013, Issue 2. [DOI: 10.1002/14651858.CD003844.pub4; PUBMED: 23450544]

\section{Pogue 1998}

Pogue J, Yusuf S. Overcoming the limitations of current meta-analysis of randomised controlled trials. Lancet 1998;351(9095):47-52. [PUBMED: 9433436]

\section{Review Manager 2014 [Computer program]}

Nordic Cochrane Centre, The Cochrane Collaboration. Review Manager 5 (RevMan 5). Version 5.3. Copenhagen: Nordic Cochrane Centre, The Cochrane Collaboration, 2014.

\section{Rucker 2011}

Rucker G, Schwarzer G, Carpenter JR, Binder H, Schumacher M. Treatment-effect estimates adjusted for small-study effects via a limit meta-analysis. Biostatistics 2011;12(1):122-42. [PUBMED: 20656692]

\section{Rusca 2003}

Rusca M, Proietti S, Schnyder P, Frascarolo P, Hedenstierna G, Spahn DR, et al. Prevention of atelectasis formation during induction of general anaesthesia. Anesthesia and Analgesia 2003;97(6):1835-9. [PUBMED: 14633570]

\section{Serpa Neto 2012}

Serpa Neto A, Cardoso SO, Manetta JA, Pereira VG, Esposito DC, Pasqualucci Mde $\mathrm{O}$, et al. Association between use of lungprotective ventilation with lower tidal volumes and clinical outcomes among patients without acute respiratory distress syndrome: a meta-analysis. JAMA 2012;308(16):1651-9. [DOI: 10.1001/jama.2012.13730; PUBMED: 23093163] 


\section{Serpa Neto 2015a}

Serpa Neto A, Simonis FD, Barbas CS, Biehl M, Determann RM, Elmer J, et al. Lung-protective ventilation with low tidal volumes and the occurrence of pulmonary complications in patients without acute respiratory distress syndrome: a systematic review and individual patient data analysis. Critical Care Medicine 2015;43(10):2155-63. [DOI: 10.1097/ CCM.0000000000001189; PUBMED: 26181219]

\section{Serpa Neto 2015b}

Serpa Neto A, Hemmes SN, Barbas CS, Beiderlinden M, Biehl M, Binnekade JM, et al. Protective versus conventional ventilation for surgery: a systematic review and individual patient data meta-analysis. Anesthesiology 2015;123(1):66-78. [DOI: 10.1097/ ALN.0000000000000706; PUBMED: 25978326]

\section{Tao 2014}

Tao T, Bo L, Chen F, Xie Q, Zou Y, Hu B, et al. Effect of protective ventilation on postoperative pulmonary complications in patients undergoing general anaesthesia: a meta-analysis of randomised controlled trials. BMJ Open 2014;4(6):e005208.

[DOI: 10.1136/bmjopen-2014-005208; PUBMED: 24961718]

\section{Tusman 2014}

Tusman G, Groisman I, Fiolo FE, Scandurra A, Arca JM, Krumrick $\mathrm{G}$, et al. Noninvasive monitoring of lung recruitment

\section{CHARACTERISTICS OF STUDIES}

Characteristics of included studies [ordered by study ID] maneuvers in morbidly obese patients: the role of pulse oximetry and volumetric capnography. Anaesthesia and Analgesia 2014;118(1):137-44. [PUBMED: 24356163]

\section{References to other published versions of this review \\ Guay 2015}

Guay J, Ochroch EA. Intraoperative use of low volume ventilation to decrease postoperative mortality, mechanical ventilation, lengths of stay and lung injury in patients without acute lung injury. Cochrane Database of Systematic Reviews 2015, Issue 12. [DOI: 10.1002/14651858.CD011151.pub2]

\section{Nguyen 2014}

Nguyen D-N, Guay J, Ochroch EA. Intraoperative use of low volume ventilation to decrease postoperative mortality, mechanical ventilation, lengths of stay and lung injury in patients without acute lung injury. Cochrane Database of Systematic Reviews 2014, Issue 6. [DOI: 10.1002/14651858.CD011151]

* Indicates the major publication for the study

Bates 2015

Rethods with parallel groups
Approved by the local ethics committee and informed consents obtained
Site: University of California, San Diego Medical Center, San Diego, CA, USA
Setting: university hospital
Dates of data collection: September 2008 to March 2011
Clinicaltrials.gov: NCT00747045

Participants

128 participants undergoing pulmonary thromboendarterectomy

Exclusion criteria: aged < 18 years, planned concurrent procedure (coronary artery bypass graft, valve replacement or lung biopsy), morbid obesity (BMI $\left.40 \mathrm{~kg} / \mathrm{m}^{2}\right)$, history of ARDS and inability or refusal to give informed consent

Interventions

Treatment group: low tidal volume $6 \mathrm{~mL} / \mathrm{kg}$ predicted body weight intra- and postoperatively for 3 days after surgery $(n=63)$

Control group: usual care with tidal volume $10 \mathrm{~mL} / \mathrm{kg}(\mathrm{n}=65)$

All participants received ventilation via a pressure-regulated volume control mode and underwent a recruitment manoeuvre on arrival to the ICU

Thereafter, titration of $\mathrm{FiO}_{2}, \mathrm{PEEP}$ and respiratory rate for both groups were guided by a modified ARDS Network protocol 
Bates 2015 (Continued)

In the event that it was not possible to meet the goals despite adherence to the aforementioned protocol, then an increase in tidal volume was permitted.

Participants were considered ready for extubation from a pulmonary mechanics standpoint if their rapid shallow breathing index was $<105$ for 30 min

Relevant to this review
1. Mortality
2. ICU length of stay
3. Hospital length of stay
4. Pneumothorax
Others
1. Incidence of reperfusion lung injury
2. Plateau pressures
3. Peak inspiratory pressures
4. Mean airway pressures
5. PaO $/$ FiO 2
6. Days on mechanical ventilation

Notes

Funding: unspecified

Declaration of interest: Dr Auger reported grants from Bayer, non-financial support from Bayer, outside the submitted work; Dr Banks had nothing to disclose; Dr Bates had nothing to disclose; Dr Duwe had nothing to disclose; Dr Fedullo reported personal fees from Actelion Pharmaceuticals, outside the submitted work; Dr Fernandes reported grants from Actelion, personal fees from Bayer, outside the submitted work; Dr Jamieson had nothing to disclose; Dr Kerr reported grants and clinical trial support from Bayer, clinical trial support from Actelion and consulting fees from Bayer, outside the submitted work; Dr Kim had nothing to disclose; Dr King had nothing to disclose; Dr Madani reported personal fees from Bayer, personal fees from Actelion, outside the submitted work; no other relationships/conditions/circumstances that presented a potential conflict of interest.

All participants were routinely kept on invasive ventilation after surgery, therefore, this outcome was not entered in the analysis.

Median duration of mechanical ventilation: 1 day for each group $(P=0.665)$

Volume per body weight: predicted body weight calculated based on the equation used by the ARDS Network in their clinical trials: predicted body weight of men: equal to $50+0.91$ (centimetres of height - 152.4); women equal to $45.5+0.91$ (centimetres of height -152.4 )

\section{Risk of bias}

\section{Bias \\ Authors' judgement Support for judgement}

Random sequence genera- Low risk tion (selection bias)
Participants underwent simple 1:1 randomization to either the treatment or control group.

Randomization was determined by the Investigational Drug Pharmacy, which used a computer program designed to generate a random allocation sequence

$\begin{array}{ll}\begin{array}{l}\text { Allocation concealment } \\ \text { (selection bias) }\end{array} & \begin{array}{l}\text { The randomization list was kept in the study file, and each participant was as- } \\ \text { signed a study group based } \\ \text { on the sequential study identification number given by the research co-ordi- } \\ \text { nator on enrolment }\end{array}\end{array}$




\section{Bates 2015 (Continued)}

Blinding of participants and personnel (perfor-

High risk The primary clinical team was not blinded to the participant's assigned group. mance bias)

All outcomes

\section{Blinding of outcome as- Unclear risk sessment (detection bias)} All outcomes
The presence of reperfusion lung injury was determined by 2 pulmonologists with extensive experience in the care of people undergoing pulmonary thromboendarterectomy, blinded to the identity of the participant and study group assignment.
Incomplete outcome data Low risk (attrition bias)

All outcomes
After enrolment and randomization, 6 participants were excluded from analysis: 4 had a diagnosis other than chronic thromboembolic pulmonary hypertension made at the time of surgery, 1 had anaphylaxis during induction of anaesthesia and 1 underwent simultaneous coronary artery bypass graft in addition to pulmonary thromboendarterectomy.

$\begin{array}{lll}\begin{array}{l}\text { Selective reporting (re- } \\ \text { porting bias) }\end{array} & \text { Low risk results reported }\end{array}$

\begin{tabular}{ll}
\hline Other bias & Analysed using intention-to-treat method \\
& $\begin{array}{l}\text { There were no significant differences in age, sex, race, actual body weight, pre- } \\
\text { dicted body weight and New York Heart Association functional class between } \\
\text { the } 2 \text { groups. }\end{array}$
\end{tabular}

\section{Chaney 2000}

$\begin{array}{ll}\text { Methods } & \text { RCT with parallel groups } \\ \text { Institutional review board approval and informed consents obtained } \\ \text { Site: Loyola University Medical Center } \\ \text { Setting: university hospital } \\ \text { Dates of data collection: unspecified }\end{array}$

Participants

25 participants scheduled for elective coronary artery bypass graft surgery and early tracheal extubation

Exclusion criteria: previous lung surgery or who required preoperative mechanical ventilation

Interventions

Treatment group: tidal volume $6 \mathrm{~mL} / \mathrm{kg} ; \mathrm{FiO}_{2}$ 1.0; respiratory rate 16 breaths/min; and

PEEP 5, after tracheal intubation $(n=12)$

Control group: tidal volume $12 \mathrm{~mL} / \mathrm{kg}$; respiratory rate 8 breaths/min; $\mathrm{FiO}_{2} 1.0$; and $\mathrm{PEEP} 5 \mathrm{cmH}_{2} \mathrm{O}$, after tracheal intubation $(n=13)$

In both groups, the inspiratory/expiratory ratio was 1:3, and the inspiratory flow was adjusted so that the calculated tidal volume was delivered during the entire inspiratory cycle (creating the lowest peak airway pressure). Each mode of ventilation (conventional or protective) was used during the entire intraoperative period and during the first hour after arrival in the ICU. After 1 hour following ICU arrival (and after last data collection time), all participants received mechanical ventilation parameters of respiratory rate 10 breaths/min; tidal volume $8 \mathrm{~mL} / \mathrm{kg}$; $\mathrm{FiO}_{2} 1.0$ and PEEP 15, and were weaned from mechanical ventilation according to the normal ICU protocol. Criteria for extubation in the ICU at this institution included an appropriate sensorium, normothermia, haemodynamic stability, adequate pul- 
Chaney 2000 (Continued) monary function $\left(\mathrm{PaO}_{2}>60 \mathrm{mmHg}\right.$ with a $\left.\mathrm{FiO}_{2} \mathrm{0.4}\right)$, adequate urine output and minimal chest tube output.

Relevant to this review
1. Need for invasive ventilatory support
2. Hospital length of stay
3. Mortality at 7 and 30 days (during hospital stay: mean hospital
12.9) days)
Others
1. Mean postoperative increase in peak inspiratory pressure
2. Mean postoperative increase in plateau inspiratory pressure
3. Mean postoperative decrease in dynamic lung compliance
4. Mean postoperative decrease in static lung compliance
5. Mean postoperative shunt

Notes

Funding: supported by Loyola University Medical Center, Department of Anesthesiology, Research Fund

Declaration of interest: none mentioned

Postoperative complications and treatments were recorded daily until hospital discharge

Volume per body weight: method used to determine body weight unspecified

\section{Risk of bias}

\begin{tabular}{|c|c|c|}
\hline Bias & Authors' judgement & Support for judgement \\
\hline $\begin{array}{l}\text { Random sequence genera- } \\
\text { tion (selection bias) }\end{array}$ & Low risk & $\begin{array}{l}\text { Quote: "each patient was randomized to one of two groups by a random num- } \\
\text { bers table." }\end{array}$ \\
\hline $\begin{array}{l}\text { Allocation concealment } \\
\text { (selection bias) }\end{array}$ & Unclear risk & Quote: "before arriving in the operating room"; no other details. \\
\hline $\begin{array}{l}\text { Blinding of participants } \\
\text { and personnel (perfor- } \\
\text { mance bias) } \\
\text { All outcomes }\end{array}$ & Unclear risk & Not mentioned \\
\hline $\begin{array}{l}\text { Blinding of outcome as- } \\
\text { sessment (detection bias) } \\
\text { All outcomes }\end{array}$ & Unclear risk & Not mentioned \\
\hline $\begin{array}{l}\text { Incomplete outcome data } \\
\text { (attrition bias) } \\
\text { All outcomes }\end{array}$ & Low risk & No loss to follow-up \\
\hline $\begin{array}{l}\text { Selective reporting (re- } \\
\text { porting bias) }\end{array}$ & Low risk & All results reported \\
\hline Other bias & Low risk & Groups well balanced \\
\hline
\end{tabular}




\begin{tabular}{|c|c|}
\hline \multirow[t]{5}{*}{ Methods } & RCT with parallel groups \\
\hline & $\begin{array}{l}\text { Approved by the Medical Ethics Committee of the University of Amsterdam (Amsterdam, The Nether- } \\
\text { lands), and informed consents obtained from all participants }\end{array}$ \\
\hline & Site: Academic Medical Center, University of Amsterdam, The Netherlands \\
\hline & Setting: university hospital \\
\hline & Dates of data collection: December 2003 to March 2005 \\
\hline \multirow[t]{2}{*}{ Participants } & 46 adults scheduled to undergo a surgical procedure of $\geq 5$ hours \\
\hline & $\begin{array}{l}\text { Exclusion criteria: history of any lung disease, use of immunosuppressive medication, recent infections, } \\
\text { previous thromboembolic disease or recent admission to ICU for ventilatory support }\end{array}$ \\
\hline \multirow[t]{3}{*}{ Interventions } & $\begin{array}{l}\text { Treatment group: tidal volume } 6 \mathrm{~mL} / \mathrm{kg}(\mathrm{IBW}) \text { and PEEP } 10 \mathrm{cmH}_{2} \mathrm{O}(\mathrm{n}=24 \text { randomized; } \mathrm{n}=21 \\
\text { analysed) }\end{array}$ \\
\hline & Control group: tidal volume $12 \mathrm{~mL} / \mathrm{kg}(\mathrm{IBW})$ and no PEEP $(\mathrm{n}=22$ randomized; and $\mathrm{n}=19$ analysed) \\
\hline & $\begin{array}{l}\text { The ventilatory protocol consisted of volume-controlled mechanical ventilation at an } \mathrm{FiO}_{2} \text { of } 0.4 \text {, inspi- } \\
\text { ratory/expiratory ratio of } 1: 2 \text { and a respiratory rate adjusted to normocapnia. If the surgical procedure } \\
\text { exceeded } 5 \text { hours, anaesthesiologists were allowed to change the ventilation strategy }\end{array}$ \\
\hline
\end{tabular}

\begin{tabular}{|c|c|}
\hline \multirow[t]{5}{*}{ Outcomes } & Relevant to this review \\
\hline & 1. Invasive ventilation $<7$ days \\
\hline & 2. Mortality during hospital stay (taken as $<30$ days) \\
\hline & Others \\
\hline & $\begin{array}{l}\text { 1. Bronchoalveolar coagulation: thrombin-antithrombin complexes, soluble tissue factor, factor VIla, } \\
\text { soluble thrombomodulin, activated protein C and fibrinolytic activity }\end{array}$ \\
\hline
\end{tabular}

Declaration of interest: none mentioned

Participants were followed up until hospital discharge or death

Volume per body weight: predicted body weight calculated based on the equation used by the ARDS Network in their clinical trials: predicted body weight of men: equal to $50+0.91$ (centimetres of height - 152.4); women: equal to $45.5+0.91$ (centimetres of height -152.4 )

\section{Risk of bias}

\begin{tabular}{lll}
\hline Bias & Authors' judgement & Support for judgement \\
\hline $\begin{array}{l}\text { Random sequence genera- } \\
\text { tion (selection bias) }\end{array}$ & Low risk & Quote: "randomization was performed by drawing a presealed envelope." \\
\hline $\begin{array}{l}\text { Allocation concealment } \\
\text { (selection bias) }\end{array}$ & Low risk & Quote: "randomization was performed by drawing a presealed envelope." \\
\hline $\begin{array}{l}\text { Blinding of participants } \\
\text { and personnel (perfor- } \\
\text { mance bias) } \\
\text { All outcomes }\end{array}$ & Unclear risk & Not mentioned \\
\hline
\end{tabular}


Choi 2006 (Continued)

Blinding of outcome as-
sessment (detection bias)

All outcomes

\begin{tabular}{lll}
\hline $\begin{array}{l}\text { Incomplete outcome data } \\
\text { (attrition bias) } \\
\text { All outcomes }\end{array}$ & Low risk & All participants accounted for and low rate of dropout \\
\hline $\begin{array}{l}\text { Selective reporting (re- } \\
\text { porting bias) }\end{array}$ & Low risk & All results reported \\
\hline Other bias & Low risk & Groups well balanced \\
& $\begin{array}{l}\text { Not intention-to-treat: quote: "five patients were randomized but excluded } \\
\text { from final analysis, because the initial surgical procedure was converted by } \\
\text { the surgeon into another shorter operation (<3 hours). One patient was ran- } \\
\text { domized, but no lavages were performed upon the surgeon's request after in- } \\
\text { duction of anaesthesia." }\end{array}$ \\
\hline
\end{tabular}

\section{Chugh 2012}

\begin{tabular}{ll}
\hline Methods & RCT with parallel groups \\
Approved by the institutional ethical committee and written informed consents obtained from all par- \\
ticipants \\
Site: University College of Medical Sciences, Delhi, India \\
Setting: university hospital \\
Dates of data collection: unspecified \\
\hline Participants \\
\hline Interventions & Treatment group: tidal volume $6 \mathrm{~mL} / \mathrm{kg}(\mathrm{IBW})$ and PEEP $10 \mathrm{cmH} \mathrm{H}_{2} \mathrm{O}(\mathrm{n}=30)$ \\
Control group: tidal volume $10 \mathrm{~mL} / \mathrm{kg}(\mathrm{IBW})$ and no PEEP $(\mathrm{n}=30)$ \\
In both groups, respiratory rate was varied to maintain eucapnia
\end{tabular}

\section{Outcomes Relevant to this review}

1. Hospital length of stay

2. Mortality at 30 days (in hospital for a mean hospital length of stay of 9 days)

\section{Others}

1. Multiple organ dysfunction/failure (maximum sepsis-related organ failure assessment score)

2. Plasma levels of interleukin- 6 and tumour necrosis factor $\alpha$

3. Minute ventilation

4. End-tidal carbon dioxide

5. Intraoperative haemodynamic parameters

6. Duration of mechanical ventilation 
Chugh 2012 (Continued)

Conference abstract

Volume per body weight: IBW, no further details

\section{Risk of bias}

Bias Authors' judgement Support for judgement

Random sequence genera- Low risk Quote: "computer generated random number table" tion (selection bias)

\begin{tabular}{ll}
\hline $\begin{array}{l}\text { Allocation concealment } \\
\text { (selection bias) }\end{array}$ & Unclear risk \\
\end{tabular}

Blinding of participants Unclear risk Quote: "double-blind." Details of blinding not provided
and personnel (perfor-
mance bias)
All outcomes

\begin{tabular}{lll}
\hline $\begin{array}{l}\text { Blinding of outcome as- } \\
\text { sessment (detection bias) }\end{array}$ & Low risk & \\
All outcomes & \\
\hline $\begin{array}{l}\text { Incomplete outcome data } \\
\text { (attrition bias) }\end{array}$ & Low risk & No loss to follow-up \\
All outcomes & \\
\hline
\end{tabular}

\begin{tabular}{lll}
\hline $\begin{array}{l}\text { Selective reporting (re- } \\
\text { porting bias) }\end{array}$ & Low risk & All results reported \\
\hline Other bias & Low risk & Baseline characteristics were similar in both groups. \\
\hline
\end{tabular}

Fernandez-Bustamante 2014

\begin{tabular}{|c|c|}
\hline \multirow[t]{5}{*}{ Methods } & RCT with parallel groups \\
\hline & $\begin{array}{l}\text { The experimental protocol was approved by the University of Colorado Multiple Institutional Review } \\
\text { Board (Aurora, Colorado) before performing the study and informed consents were obtained. }\end{array}$ \\
\hline & Site: Webb-Waring Center, University of Colorado School of Medicine, Aurora, Colorado \\
\hline & Setting: university hospital \\
\hline & Dates of data collection: unspecified \\
\hline \multirow[t]{2}{*}{ Participants } & $\begin{array}{l}30 \text { participants scheduled to receive elective orthopaedic surgery for total knee replacement under } \\
\text { general anaesthesia }\end{array}$ \\
\hline & $\begin{array}{l}\text { Exclusion criteria: ASA class IV; aged } \geq 70 \text { years; emergency procedure; status post pneumonectomy; di- } \\
\text { agnosed with chronic obstructive pulmonary disease, emphysema, asthma, pulmonary hypertension, } \\
\text { sleep apnoea or any other respiratory disease; oxygen therapy during last month; tobacco use in the } \\
\text { last } 5 \text { years; severe obesity }\left(\mathrm{BMI} \geq 35 \mathrm{~kg} / \mathrm{m}^{2}\right) \text {; immunosuppression within } 3 \text { months before the proce- } \\
\text { dure; diagnosed infection or shock }\end{array}$ \\
\hline
\end{tabular}

$\begin{array}{ll}\text { Interventions } & \text { Treatment group: tidal volume } 6 \mathrm{~mL} / \mathrm{kg}(\mathrm{IBW})(\mathrm{n}=14) \\ & \text { Control group: tidal volume } 10 \mathrm{~mL} / \mathrm{kg}(\mathrm{IBW})(\mathrm{n}=14)\end{array}$


Fernandez-Bustamante 2014 (Continued)

The respiratory rate was titrated for eucapnia (end-tidal carbon dioxide partial pressure $30-40 \mathrm{mmHg}$ ), and all participants received the same following ventilatory settings: inspiratory/expiratory ratio, 1:2; inspiratory pause 5\%; and fresh gas flow $2 \mathrm{~L} / \mathrm{min}, \mathrm{FiO}_{2} 0.5$, PEEP $5 \mathrm{cmH}_{2} \mathrm{O}$

Relevant to this review
1. Non-invasive ventilatory support
2. Invasive ventilatory support
3. Hospital length of stay
Others
1. Exhaled nitrite; nitrate; tumour necrosis factor a; interleukins-13, -6, -8, -10 and -11; neutrophil elas-
tase and Clara cell protein 16

\section{Risk of bias}

\begin{tabular}{|c|c|c|}
\hline Bias & Authors' judgement & Support for judgement \\
\hline $\begin{array}{l}\text { Random sequence genera- } \\
\text { tion (selection bias) }\end{array}$ & Unclear risk & Quote: "randomized"; no details \\
\hline $\begin{array}{l}\text { Allocation concealment } \\
\text { (selection bias) }\end{array}$ & Unclear risk & Not mentioned \\
\hline $\begin{array}{l}\text { Blinding of participants } \\
\text { and personnel (perfor- } \\
\text { mance bias) } \\
\text { All outcomes }\end{array}$ & Unclear risk & Not mentioned \\
\hline $\begin{array}{l}\text { Blinding of outcome as- } \\
\text { sessment (detection bias) } \\
\text { All outcomes }\end{array}$ & Unclear risk & Not mentioned \\
\hline $\begin{array}{l}\text { Incomplete outcome data } \\
\text { (attrition bias) } \\
\text { All outcomes }\end{array}$ & Low risk & 30 included, 28 analysed \\
\hline $\begin{array}{l}\text { Selective reporting (re- } \\
\text { porting bias) }\end{array}$ & Low risk & All results reported \\
\hline Other bias & Low risk & $\begin{array}{l}\text { Quote: "no significant differences were found between the two groups in terms } \\
\text { of age, sex, comorbidities, ASA classification, height, weight, body mass index } \\
\text { and IBW." }\end{array}$ \\
\hline
\end{tabular}


Not intention-to-treat: quote: "one patient from each VT group was removed from the study because of a non disclosed steroid course within 10 days before surgery and previously undiagnosed sleep apnoea symptoms. Only the remaining 28 participants (14 per group) were included in the final analyses."

Futier 2013

Rethods with parallel groups
Approved by a central ethics committee (Comité de Protection
France) according to French law. Written informed consent
each participant, on the day before surgery
Site: multicentre at 7 French university teaching hospitals
Setting: university hospital
Dates of data collection: 31 January 2011 to 10 August 2012
ClinicalTrials.gov: NCT01282996

Participants

400 adults aged $>40$ years, scheduled to undergo laparoscopic or non-laparoscopic elective major abdominal surgery with an expected duration $\geq 2$ hours, and a preoperative risk index for pulmonary complications $>2$ (possible scores from 1 to 5 and a high score indicates a higher risk)

Exclusion criteria: received mechanical ventilation within the 2 weeks preceding surgery, $\mathrm{BMI} \geq 35 \mathrm{~kg} /$ $\mathrm{m}^{2}$, history of respiratory failure or sepsis within 2 weeks preceding surgery, requirement for intrathoracic or emergency surgery, or had a progressive neuromuscular illness

Interventions

Treatment group: tidal volume $6-8 \mathrm{~mL} / \mathrm{kg}$ (IBW), PEEP $6-8 \mathrm{cmH}_{2} \mathrm{O}$ and recruitment manoeuvres repeated every 30 min after tracheal intubation $\left(30 \mathrm{cmH}_{2} \mathrm{O}\right.$ for 30 seconds) $(n=200)$

Control group: tidal volume $10-12 \mathrm{~mL} / \mathrm{kg}$ (IBW), no PEEP and no recruitment manoeuvres $(\mathrm{n}=200)$

During anaesthesia, a plateau pressure $\leq 30 \mathrm{cmH}_{2} \mathrm{O}$ was targeted in each group. For episodes of arterial desaturation (defined as a peripheral oxygen saturation $\leq 92 \%$ ), a transient increase in $\mathrm{FiO}_{2}$ to $100 \%$ was permitted, and in participants assigned to the control group, the use of PEEP, recruitment manoeuvres or both was allowed, if required.

\section{Outcomes Relevant to this review}
1. Pneumonia
2. Non-invasive ventilatory support
3. Invasive ventilatory support
4. ICU length of stay
5. Mortality at 30 days

\section{Others}

1. Composite of major pulmonary and extrapulmonary complications

\section{Notes}

$$
\begin{aligned}
& \text { Funding: some authors declared consultant fees or travel expenses, or both, from industry } \\
& \text { Declaration of interest: Dr Futier reported receiving consulting fees from General Electric Medical Sys- } \\
& \text { tems, lecture fees from Fresenius Kabi, and reimbursement of travel expenses from Fisher and Paykel } \\
& \text { Healthcare. Dr Constantin reported receiving consulting fees from Baxter, Fresenius Kabi, Dräger and } \\
& \text { General Electric Medical Systems; payment for expert testimony from Baxter, Dräger and Fresenius } \\
& \text { Kabi; lecture fees from General Electric Medical Systems, Dräger, Fresenius Kabi, Baxter, Hospal, Merck } \\
& \text { Sharp \& Dohme and LFB Biomedicaments; payment for the development of educational presentations }
\end{aligned}
$$


Futier 2013 (Continued)

from Dräger, General Electric Medical Systems, Baxter and Fresenius Kabi; and reimbursement of travel expenses from Bird, Astute Medical, Astellas, Fresenius Kabi, Baxter and Hospal. Dr Paugam-Burtz reported receiving consulting fees from Fresenius Kabi, lecture fees and reimbursement of travel expenses from Astellas, and payment for the development of educational presentations from LFB Biomedicaments and Merck Sharp \& Dohme. Dr Allaouchiche reported receiving consulting fees from Fresenius Kabi and lecture fees from Novartis and Astellas. Dr Leone reported receiving consulting fees from LFB Biomedicaments and lecture fees from Fresenius Kabi and Novartis. Dr Jaber reported receiving consulting fees from Dräger France and Maquet France; lecture fees from Fisher and Paykel Healthcare, Abbott and Philips; and reimbursement of travel expenses from Pfizer. No other potential conflict of interest relevant to this article was reported.

30-day follow-up period

Volume per body weight: predicted body weight calculated based on the equation used by the ARDS Network in their clinical trials: predicted body weight: men: $50+0.91$ (height in $\mathrm{cm}-152.4$ ); women: $45.5+0.91$ (height in $\mathrm{cm}-152.4$ )

\section{Risk of bias}

\begin{tabular}{lll}
\hline Bias & Authors' judgement & Support for judgement \\
\hline $\begin{array}{ll}\text { Random sequence genera- } \\
\text { tion (selection bias) }\end{array}$ & Low risk & $\begin{array}{l}\text { Quote: "randomization was performed with the use of a computer-generated } \\
\text { assignment sequence and a centralized telephone system." }\end{array}$ \\
& $\begin{array}{l}\text { Quote: "randomization was stratified according to study site and the planned } \\
\text { use or nonuse of postoperative epidural analgesia." }\end{array}$
\end{tabular}

\begin{tabular}{lll}
\hline $\begin{array}{l}\text { Allocation concealment } \\
\text { (selection bias) }\end{array}$ & Low risk & $\begin{array}{l}\text { Quote: "randomization was performed with the use of a computer-generated } \\
\text { assignment sequence and a centralized telephone system." }\end{array}$ \\
\hline $\begin{array}{l}\text { Blinding of participants } \\
\text { and personnel (perfor- } \\
\text { mance bias) }\end{array}$ & Unclear risk & $\begin{array}{l}\text { Quote: "treatment assignments were concealed from patients, research staff, } \\
\text { the statistician, and the data and safety monitoring committee. Staff members } \\
\text { All outcomes }\end{array}$ \\
who collected data during surgery were aware of the group assignments."
\end{tabular}

\begin{tabular}{lll}
\hline $\begin{array}{l}\text { Blinding of outcome as- } \\
\text { sessment (detection bias) } \\
\text { All outcomes }\end{array}$ & Low risk & $\begin{array}{l}\text { Quote: "outcome assessors were unaware of these assignments throughout } \\
\text { the study." }\end{array}$ \\
\hline $\begin{array}{l}\text { Incomplete outcome data } \\
\text { (attrition bias) }\end{array}$ & Low risk & $\begin{array}{l}3 \text { participants were excluded after randomization; surgery was stopped pre- } \\
\text { maturely in } 2 \text { of the } 3 \text { participants because of extensive illness (duration of } \\
\text { surgery, }<2 \text { hours), and } 1 \text { had undergone randomization in error (violation of } \\
\text { exclusion criteria). An additional } 3 \text { participants were thus randomly assigned } \\
\text { to a study group to obtain the full sample. }\end{array}$ \\
\hline
\end{tabular}

Selective reporting (re- Low risk All results reported
porting bias)

Other bias Low risk Groups well balanced

Quote: "there was no industry support or involvement in the trial."

$\begin{array}{ll}\text { Methods } & \text { RCT with parallel groups } \\ \text { Approved by the ethics committee and informed consent obtained }\end{array}$


Ge 2013 (Continued)

Site: Ningbo 6th Hospital, Ningbo Zhjiang, China

Setting: hospital

Dates of data collection: July 2011 to February 2012

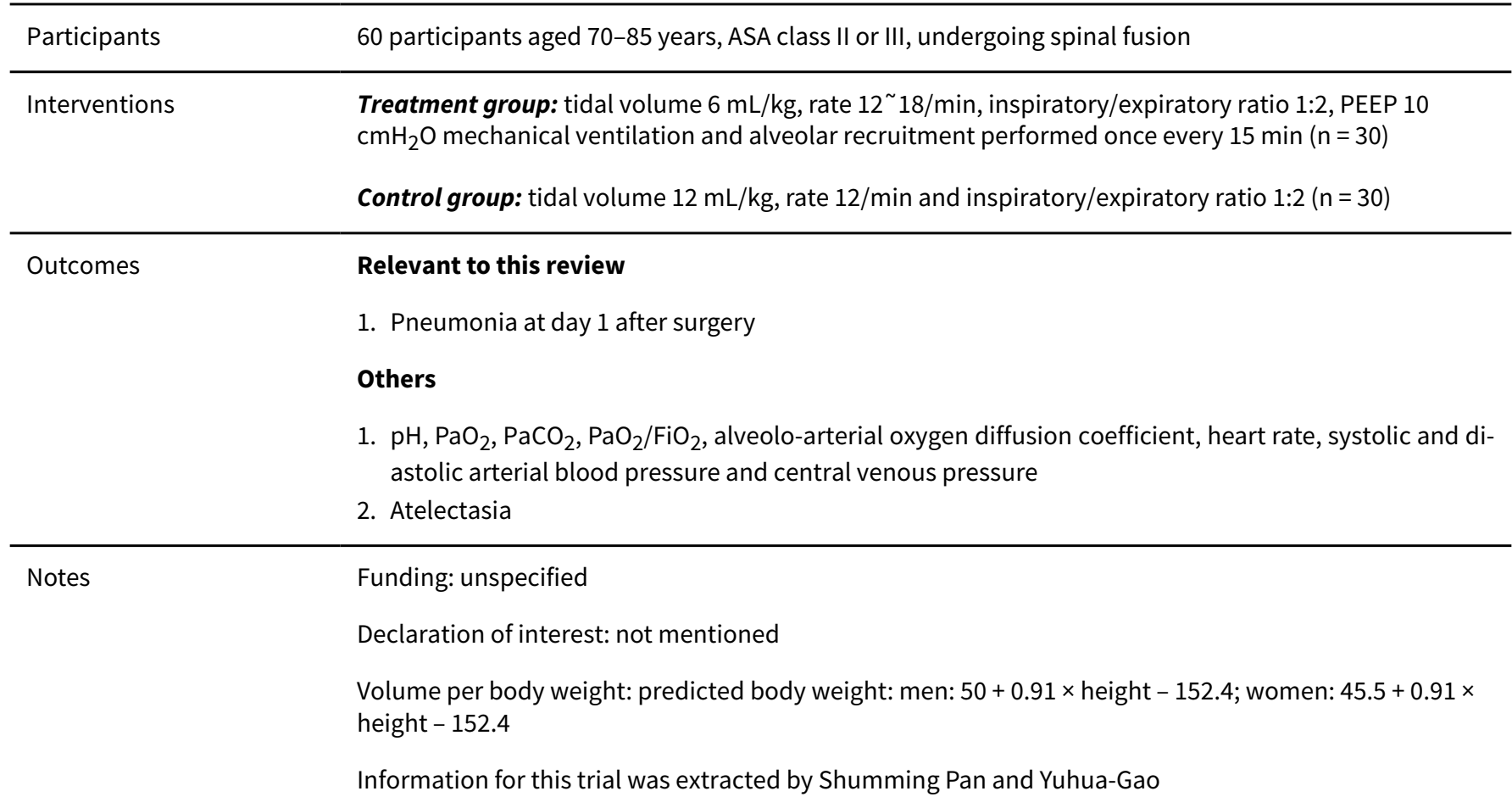

\section{Risk of bias}

\begin{tabular}{|c|c|c|}
\hline Bias & Authors' judgement & Support for judgement \\
\hline $\begin{array}{l}\text { Random sequence genera- } \\
\text { tion (selection bias) }\end{array}$ & Low risk & $\begin{array}{l}\text { Randomly assigned, from Shumming Pan and judged as "randomized con- } \\
\text { trolled trial:" by Yuhua-Gao from page } 82 \text {. }\end{array}$ \\
\hline \multirow{2}{*}{$\begin{array}{l}\text { Allocation concealment } \\
\text { (selection bias) }\end{array}$} & Unclear risk & Unclear \\
\hline & & $\begin{array}{l}\text { The allocation method allowed the record staff to know the treatment alloca- } \\
\text { tion of the next participant to be enrolled in the study. }\end{array}$ \\
\hline $\begin{array}{l}\text { Blinding of participants } \\
\text { and personnel (perfor- } \\
\text { mance bias) } \\
\text { All outcomes }\end{array}$ & High risk & $\begin{array}{l}\text { The allocation method allowed the record staff to know the treatment alloca- } \\
\text { tion of the next participant to be enrolled in the study. }\end{array}$ \\
\hline $\begin{array}{l}\text { Blinding of outcome as- } \\
\text { sessment (detection bias) } \\
\text { All outcomes }\end{array}$ & Unclear risk & $\begin{array}{l}\text { This study did not describe whether the outcome assessor was blinded to the } \\
\text { intervention. }\end{array}$ \\
\hline $\begin{array}{l}\text { Incomplete outcome data } \\
\text { (attrition bias) } \\
\text { All outcomes }\end{array}$ & Low risk & No participant selected for this study dropped out \\
\hline $\begin{array}{l}\text { Selective reporting (re- } \\
\text { porting bias) }\end{array}$ & Low risk & $\begin{array}{l}\text { All the measurements stated in the methods section were included in the re- } \\
\text { sults. }\end{array}$ \\
\hline
\end{tabular}


Ge 2013 (Continued)
Other bias
Unclear risk
No clear definition for pneumonia (possible inclusion of bronchitis or other pulmonary complications)

Koner 2004

\begin{tabular}{|c|c|}
\hline \multirow[t]{5}{*}{ Methods } & RCT with parallel groups \\
\hline & Approved by the ethics committee and written informed consents obtained \\
\hline & Site: Cardiology Institute, Istanbul University, Haseki caddesi, Aksaray-Istanbul, Turkey \\
\hline & Setting: university hospital \\
\hline & Dates of data collection: November 2001 to August 2002 \\
\hline
\end{tabular}

Participants
Exclusion criteria: acute infections, pre-existing pulmonary disease, left ventricular ejection fraction $<$
$40 \%$, myocardial infarction within 1 month, reoperation, coagulopathy, unstable angina pectoris and
renal failure

Interventions

Treatment group: tidal volume $6 \mathrm{~mL} / \mathrm{kg}$, respiratory rate: 15 breaths/min and PEEP $5 \mathrm{cmH}_{2} \mathrm{O}(\mathrm{n}=15)$

\section{Control groups:}

1. tidal volume $10 \mathrm{~mL} / \mathrm{kg}$, respiratory rate: 9 breaths $/ \mathrm{min}, \mathrm{PEEP} 5 \mathrm{cmH}_{2} \mathrm{O},(\mathrm{n}=14)$

2. tidal volume $10 \mathrm{~mL} / \mathrm{kg}$, respiratory rate: 9 breaths $/ \mathrm{min}$, no $\operatorname{PEEP}(\mathrm{n}=15)$

Before discontinuation of $\mathrm{CPB}$, the lungs were inflated manually up to $40 \mathrm{cmH}_{2} \mathrm{O}$ peak airway pressure for 20 seconds and the ventilation was started with a $\mathrm{FiO}_{2}$ of 0.6 then reduced to 0.5 . Corticosteroids, antifibrinolytic agents or aprotinin were not used and no ultrafiltration technique was employed throughout the study.

Outcomes

\section{Relevant to this review}

1. Invasive ventilatory support

2. Hospital length of stay

3. Mortality at 30 days (during hospital length of stay and mean hospital length of stay: mean 7.9 (SD 1.2) days)

\section{Others}

1. Tumour necrosis factor $\alpha$

2. Interleukin-6

3. Plateau airway pressure, shunt, oxygenation, alveolo-arterial oxygen difference

Declaration of interest: partially supported by Fresenius-Kabi and Aventis Pharma

The treatment group was split in half to compare with each control group.

As no other recruitment manoeuvre was mentioned apart from the 1 single reinflation manoeuvre just before ending CPB, for heterogeneity exploration, participants were considered as not having received recruitment manoeuvres during surgery.

Volume per body weight: IBW, no further details 
Koner 2004 (Continued)

\section{Risk of bias}

\begin{tabular}{|c|c|c|}
\hline Bias & Authors' judgement & Support for judgement \\
\hline $\begin{array}{l}\text { Random sequence genera- } \\
\text { tion (selection bias) }\end{array}$ & Unclear risk & Quote: "randomized;" no details \\
\hline $\begin{array}{l}\text { Allocation concealment } \\
\text { (selection bias) }\end{array}$ & Low risk & Quote: "following the anaesthesia induction, patients were randomized." \\
\hline $\begin{array}{l}\text { Blinding of participants } \\
\text { and personnel (perfor- } \\
\text { mance bias) } \\
\text { All outcomes }\end{array}$ & High risk & Quote: "anaesthesia and intensive care unit teams were not blinded." \\
\hline $\begin{array}{l}\text { Blinding of outcome as- } \\
\text { sessment (detection bias) } \\
\text { All outcomes }\end{array}$ & Unclear risk & Not mentioned \\
\hline $\begin{array}{l}\text { Incomplete outcome data } \\
\text { (attrition bias) } \\
\text { All outcomes }\end{array}$ & Low risk & No loss to follow-up \\
\hline $\begin{array}{l}\text { Selective reporting (re- } \\
\text { porting bias) }\end{array}$ & Low risk & All results reported \\
\hline Other bias & Low risk & Groups well balanced \\
\hline
\end{tabular}

\section{Kuzkov 2016}

\begin{tabular}{|c|c|}
\hline \multirow[t]{6}{*}{ Methods } & RCT with parallel groups \\
\hline & Approved by the ethics committee \\
\hline & Written informed consents obtained \\
\hline & Site: Northern State Medical University, Arkhangelsk, Russian Federation \\
\hline & Setting: University hospital \\
\hline & Dates of data collection: $2014-2016$ \\
\hline
\end{tabular}

In all the groups, PEEP $4 \mathrm{cmH}_{2} \mathrm{O}$ was set.

\section{Outcomes}

\section{Relevant to this review}
1. Mortality
2. Pneumonia
3. ICU length of stay
4. Hospital length of stay 
Kuzkov 2016 (Continued)

\section{Others}

1. Tidal volumes

2. $\mathrm{PaO}_{2} / \mathrm{FiO}_{2}$ ratio

3. Atelectasia

4. Arterial lactate and bicarbonate excess values

Funding: supported, in part, by the Grant of the President of Russian Federation (grant number
MD-4984.2015.7)
Declaration of interest: none mentioned
All participants were routinely kept on invasive ventilation after surgery, therefore this outcome was
not entered in the analysis.
Email send to authors to obtain results for ICU length of stay on 10 June 2017. No reply received
Volume per body weight: predicted body weight, no further details

\section{Risk of bias}

\begin{tabular}{lll}
\hline Bias & Authors' judgement & Support for judgement \\
\hline $\begin{array}{l}\text { Random sequence genera- } \\
\text { tion (selection bias) }\end{array}$ & Low risk & $\begin{array}{l}\text { Before anaesthesia and start of mechanical ventilation, participants were ran- } \\
\text { domized using the envelope method }\end{array}$ \\
\hline $\begin{array}{l}\text { Allocation concealment } \\
\text { (selection bias) }\end{array}$ & Low risk & See above \\
\hline $\begin{array}{l}\text { Blinding of participants } \\
\begin{array}{l}\text { and personnel (perfor- } \\
\text { mance bias) } \\
\text { All outcomes }\end{array}\end{array}$ & Unclear risk & Not mentioned \\
\hline
\end{tabular}

\begin{tabular}{|c|c|c|}
\hline $\begin{array}{l}\text { Blinding of outcome as- } \\
\text { sessment (detection bias) }\end{array}$ & Low risk & $\begin{array}{l}\text { Tracheal extubation was performed in the ICU by an independent ICU physi- } \\
\text { cian on predetermined criteria. }\end{array}$ \\
\hline All outcomes & & Chest X-rays were interpreted by an independent specialist. \\
\hline
\end{tabular}

\begin{tabular}{l}
\hline Incomplete outcome data Low risk No lost to follow-up \\
(attrition bias) \\
All outcomes
\end{tabular}

\begin{tabular}{lll}
\hline $\begin{array}{l}\text { Selective reporting (re- } \\
\text { porting bias) }\end{array}$ & Low risk & All results reported \\
\hline Other bias & Unclear risk & $\begin{array}{l}\text { Groups well balanced except for smoking that was significantly lower in the } \\
\text { high tidal volume group }(\mathrm{P}=0.03)\end{array}$ \\
\hline
\end{tabular}

RCT with parallel groups
Approved by the Hospital for Special Surgery Institutional Review Board (Protocol no. 28117) and writ-
ten, informed consents obtained
Site: Hospital for Special Surgery, New York, NY, USA


Memtsoudis 2012 (Continued)

Setting: hospital

Dates of data collection: February 2009 to September 2010

Participants 26 participants scheduled for elective, primary lumbar decompression and fusion of $\leq 4$ spinal levels
Exclusion criteria: known previous lung pathology, use of immunosuppressants, renal failure with crea-
tinine $>1.5 \mathrm{mg} / \mathrm{dL}$, recent exposure to a ventilator or surgery during general anaesthesia ( $<1$ year), and
ASA physical status $\geq$ III

\begin{tabular}{ll}
\hline Interventions & Treatment group: tidal volume $6 \mathrm{~mL} / \mathrm{kg}(\mathrm{IBW})$ and $\mathrm{PEEP} 8 \mathrm{cmH} \mathrm{C}_{2} \mathrm{O}(\mathrm{n}=13)$ \\
Control group: tidal volume $12 \mathrm{~mL} / \mathrm{kg}(\mathrm{IBW})$ and no PEEP $(\mathrm{n}=13)$
\end{tabular}

\begin{tabular}{ll}
\hline Outcomes & Relevant to this review \\
1. Invasive ventilatory support \\
Others \\
1. Plasma levels of interleukin- 6 and -8 \\
2. Urinary levels of desmosine
\end{tabular}

Notes

Funding: Department of Anesthesiology, Hospital for Special Surgery (Stavros G. Memtsoudis), and Clinical Translational Science Center (CTSC) grant: NIH UL1-RR024996 (Yan Ma)

Declaration of interest: none mentioned

Volume per body weight: IBW: men: $50+0.91$ (height in $\mathrm{cm}-152.4$ ); women $45.5+0.91$ (height in $\mathrm{cm}$ 152.4)

\section{Risk of bias}

\begin{tabular}{|c|c|c|}
\hline Bias & Authors' judgement & Support for judgement \\
\hline $\begin{array}{l}\text { Random sequence genera- } \\
\text { tion (selection bias) }\end{array}$ & Low risk & $\begin{array}{l}\text { Quote: "patients were randomly assigned by a computer generated list of ran- } \\
\text { dom numbers." }\end{array}$ \\
\hline $\begin{array}{l}\text { Allocation concealment } \\
\text { (selection bias) }\end{array}$ & Low risk & $\begin{array}{l}\text { Quote: "the allocation sequence was concealed from the research assistant in } \\
\text { sequentially numbered, opaque, sealed, and stapled envelopes." }\end{array}$ \\
\hline $\begin{array}{l}\text { Blinding of participants } \\
\text { and personnel (perfor- } \\
\text { mance bias) } \\
\text { All outcomes }\end{array}$ & Unclear risk & Not mentioned \\
\hline $\begin{array}{l}\text { Blinding of outcome as- } \\
\text { sessment (detection bias) } \\
\text { All outcomes }\end{array}$ & Low risk & $\begin{array}{l}\text { Quote: "patients, surgeons, and research assistants who were responsible for } \\
\text { subsequent data collection were blinded to the randomization." }\end{array}$ \\
\hline $\begin{array}{l}\text { Incomplete outcome data } \\
\text { (attrition bias) } \\
\text { All outcomes }\end{array}$ & Low risk & $\begin{array}{l}\text { Quote: "one patient in the low tidal volume group withdrew consent for blood } \\
\text { draws after randomization and surgery." }\end{array}$ \\
\hline $\begin{array}{l}\text { Selective reporting (re- } \\
\text { porting bias) }\end{array}$ & Low risk & All results reported \\
\hline Other bias & Low risk & $\begin{array}{l}\text { Quote: "despite randomization, patients in the low volume group were older } \\
(P \text { value }=0.01) . "\end{array}$ \\
\hline
\end{tabular}




RCT with parallel groups
Approved by the ethics committee
Written informed consents obtained
Site: Seoul National University College of Medicine, South Korea
Setting: university hospital
Dates: November 2012 to June 2014
Clinical Research Information Service: KCT0001034

Participants participants undergoing laparoscopic hepatobiliary surgery
Exclusion criteria: cardiopulmonary or hepatorenal disease, recent infections, recent ventilator sup-
port, previous thromboembolic disease or denial of informed consent

Interventions

Treatment group: tidal volume $6 \mathrm{~mL} / \mathrm{kg}\left(\right.$ IBW) and PEEP of $5 \mathrm{cmH}_{2} \mathrm{O}(\mathrm{n}=31)$

Control group: tidal volume $10 \mathrm{~mL} / \mathrm{kg}$ (IBW) and recruitment manoeuvres at $40 \mathrm{cmH}_{2} \mathrm{O}$ for 30 seconds $(n=31)$

All groups used volume-controlled ventilation, inspiration/expiration ratio $1: 2$ and $\mathrm{FiO}_{2} 0.5$ in medical air

Relevant to this review
1. Pneumonia
2. Need for postoperative invasive ventilation between discharge from the postoperative care unit and
7 days after the surgery
3. Hospital length of stay
4. Pneumothorax (barotrauma)
Others
1. Atelectasis
2. Desaturation
3. Arterial blood gas
4. Peak inspiratory pressure
5. Haemodynamic variables
Funding: supported by Grant No. 02-2013-072 from Seoul National University Bundang Hospital Re-
search Fund
Declaration of interest: Drs Park, Ryu, Kim, Oh, Han (S.H) and Han (H.S) had no conflicts of interest or fi-
nancial ties to disclose
Volume per body weight: IBW, no further details

\section{Risk of bias}

\begin{tabular}{lll}
\hline Bias & Authors' judgement & Support for judgement \\
\hline $\begin{array}{ll}\text { Random sequence genera- } \\
\text { tion (selection bias) }\end{array}$ & Low risk & $\begin{array}{l}\text { Randomization performed before induction of anaesthesia by an anaesthesiol- } \\
\text { ogist not otherwise involved in study. Used computer-generated random num- }\end{array}$
\end{tabular}




\begin{tabular}{ll}
\hline $\begin{array}{l}\text { Allocation concealment } \\
\text { (selection bias) }\end{array}$ & Unclear risk
\end{tabular}$\quad \begin{aligned} & \text { From a table of random numbers, participants were allocated to convention- } \\
& \text { al ventilation with alveolar recruitment manoeuvres }(n=31) \text { or protective lung } \\
& \text { ventilation strategy group }(n=31) .\end{aligned}$

\begin{tabular}{|c|c|c|}
\hline $\begin{array}{l}\text { Blinding of participants } \\
\text { and personnel (perfor- } \\
\text { mance bias) }\end{array}$ & Unclear risk & $\begin{array}{l}\text { Participants and outcome assessors blinded to group assignment. Howev- } \\
\text { er, anaesthesiologist responsible for ventilator setting and the care of partici- } \\
\text { pants during surgery was not blinded to assigned group. }\end{array}$ \\
\hline
\end{tabular}

All outcomes

Blinding of outcome as- Low risk Outcome assessors blinded to group assignment

sessment (detection bias)

All outcomes

\section{Incomplete outcome data High risk}

(attrition bias)

All outcomes

\begin{abstract}
After randomization, 12 participants in control group and 10 participants in treament group were excluded due to conversion to open surgery and ICU admission without extubation.
\end{abstract}

For this review, the participant who required postoperative invasive ventilation was included for the outcome need of postoperative invasive ventilation according to the intention-to-treat principle.

39 participants (19 participants in alveolar recruitment manoeuvre group and 20 participants in protective lung ventilation strategy group) completed the study and were analysed.

\begin{tabular}{lll}
\hline $\begin{array}{l}\text { Selective reporting (re- } \\
\text { porting bias) }\end{array}$ & Low risk & All results reported \\
\hline Other bias & Low risk & Groups well balanced \\
\hline
\end{tabular}

\section{Sato 2016}

RCT with parallel groups
Approved by the ethics committee
Written informed consents obtained
Site: Yokohama City University Hospital
Setting: university hospital
Dates of data collection: October 2008 to September 2009
UMIN-CTR: UMIN000021371 (3 July 2016); retrospectively registered

28 participants aged 20-85 years undergoing hepatectomy
Exclusion criteria: ASA physical status $\geq$ III, pre-existing lung disease, tumour in the portal vein or inferi-
or vena cava, requirement of bile duct or gastrointestinal tract repair, or requirement of additional sur-
gical procedures other than hepatectomy

Interventions

Treatment group: tidal volume $6 \mathrm{~mL} / \mathrm{kg}$ (predicted body weight) $(\mathrm{n}=14)$

Control group: tidal volume $12 \mathrm{~mL} / \mathrm{kg}$ (predicted body weight) $(\mathrm{n}=14)$ 
Sato 2016 (Continued)

Outcomes

\section{Relevant to this review}

1. Need for postoperative invasive ventilation between discharge from the postoperative care unit and 7 days after the surgery

2. Hospital length of stay

\section{Others}

1. Haemodynamic parameters

2. Acid-base status

3. Oxygenation

4. Interleukin-8 in epithelial lining fluid

Notes Funding: supported by the Center for Advanced Medical Promotion of the Yokohama City University Graduate School of Medicine (grant number: 07-021) and the Grants-in-Aid for Scientific Research from the Japan Society for the Promotion of Science (grant number: 26462368)

Declaration of interest: the authors declared that they had no competing interests.

Volume per body weight: predicted body weight, no further details

\section{Risk of bias}

\begin{tabular}{|c|c|c|}
\hline Bias & Authors' judgement & Support for judgement \\
\hline $\begin{array}{l}\text { Random sequence genera- } \\
\text { tion (selection bias) }\end{array}$ & Low risk & $\begin{array}{l}\text { Assignment performed using a random number table by an investigator who } \\
\text { was not involved in data collection and was notified to anaesthesiologists who } \\
\text { were not involved in study using an envelope method. }\end{array}$ \\
\hline $\begin{array}{l}\text { Allocation concealment } \\
\text { (selection bias) }\end{array}$ & Low risk & $\begin{array}{l}\text { Assignment performed using a random number table by an investigator who } \\
\text { was not involved in data collection and was notified to anaesthesiologists who } \\
\text { were not involved in study using an envelope method. }\end{array}$ \\
\hline $\begin{array}{l}\text { Blinding of participants } \\
\text { and personnel (perfor- } \\
\text { mance bias) } \\
\text { All outcomes }\end{array}$ & Unclear risk & Not mentioned \\
\hline $\begin{array}{l}\text { Blinding of outcome as- } \\
\text { sessment (detection bias) } \\
\text { All outcomes }\end{array}$ & Low risk & $\begin{array}{l}\text { Investigators who collected the data and samples were blinded to the ventila- } \\
\text { tion settings at any time of the experiment }\end{array}$ \\
\hline $\begin{array}{l}\text { Incomplete outcome data } \\
\text { (attrition bias) } \\
\text { All outcomes }\end{array}$ & Low risk & $\begin{array}{l}3 \text { participants in the high tidal volume group were excluded because the oper- } \\
\text { ation was terminated before the completion of the study due to dissemination } \\
\text { of tumour to the peritoneum. }\end{array}$ \\
\hline $\begin{array}{l}\text { Selective reporting (re- } \\
\text { porting bias) }\end{array}$ & Low risk & All results reported \\
\hline Other bias & Low risk & Groups well balanced \\
\hline
\end{tabular}

Shen 2015

$\begin{array}{ll}\text { Methods } & \text { RCT with parallel groups } \\ \text { Written informed consents obtained }\end{array}$

Intraoperative use of low volume ventilation to decrease postoperative mortality, mechanical ventilation, lengths of stay and lung injury 
Shen 2015 (Continued)

Site: Ruijin Hospital North of Shanghai Jiatong University, China

Setting: university hospital

Dates of data collection: January 2013 to December 2014

Participants
$\begin{aligned} & 120 \text { participants at high risk of postoperative pulmonary complications: } 2 \text { hours' duration, need for } \\ & \text { postoperative ICU admission, postoperative pulmonary complication risk score } 25\end{aligned}$

Interventions Treatment group: tidal volume $6 \mathrm{~mL} / \mathrm{kg}, \mathrm{PEEP} 6 \mathrm{cmH}_{2} \mathrm{O}$ and 1 recruitment manoeuvre per hour (30 $\mathrm{cmH}_{2} \mathrm{O}$ for 30 seconds) $(\mathrm{n}=60)$

Control group: tidal volume $10 \mathrm{~mL} / \mathrm{kg}$, PEEP $0 \mathrm{cmH}_{2} \mathrm{O}(\mathrm{n}=60)$

Outcomes
Relevant to this review
1. Mortality
2. Pneumonia
3. ICU length of stay
4. Length of hospital stay
Others
1. Arterial blood gas values
2. Tidal volume
3. Peak airway pressure
4. Plateau airway pressure
5. Oxygenation index
6. Static compliance
7. Dynamic compliance

Notes Funding: departmental resources

Declaration of interest: none mentioned

Email sent to authors 11 June 2017 to request results for pneumonia: invalid email address. Letter sent 19 June 2017. No reply received

Volume per body weight: predicted body weight: men: height in $\mathrm{cm}-105$; women: height in $\mathrm{cm}-110$

\section{Risk of bias}

\begin{tabular}{lll}
\hline Bias & Authors' judgement & Support for judgement \\
\hline $\begin{array}{l}\text { Random sequence genera- } \\
\text { tion (selection bias) }\end{array}$ & Unclear risk & Quote: "randomly assigned," no details \\
\hline $\begin{array}{l}\text { Allocation concealment } \\
\text { (selection bias) }\end{array}$ & Unclear risk & Not mentioned \\
\hline $\begin{array}{l}\text { Blinding of participants } \\
\text { and personnel (perfor- } \\
\text { mance bias) } \\
\text { All outcomes }\end{array}$ & Unclear risk & Not mentioned \\
\hline
\end{tabular}

$\begin{array}{lll}\text { Blinding of outcome as- } & \text { Unclear risk } & \text { Not mentioned } \\ \text { sessment (detection bias) } & \end{array}$

All outcomes 
Shen 2015 (Continued)

Incomplete outcome data Low risk No lost to follow-up
(attrition bias)

All outcomes

Selective reporting (re- Low risk $\quad$ All results reported
porting bias)

Other bias Low risk Groups well balanced

Soh 2018

Rethods with parallel groups
Approved by the local ethics committee
Informed consents obtained
Site: Severance Cardiovascular Hospital, Yonsei University College of Medicine, 50 Yonsei-ro, Seodae-
mun-gu, Seoul, Republic of Korea
Setting: university hospital
Dates of data collection: January 2015 to January 2016
Clinicaltrials.gov: NCT02373475

Participants
$\begin{aligned} & \text { spinal surgery in the prone position under general anaesthesia for }>2 \text { hours, and preoperative risk in- } \\ & \text { dex for postoperative pulmonary complications } \geq 2\end{aligned}$
Exclusion criteria: increased intracranial pressure or altered mental status before surgery; any neuro-
muscular disease; $\mathrm{BMI}>35 \mathrm{~kg} / \mathrm{m}^{2} ;$ previous lung surgery; repeated treatment for acute exacerbation of
asthma or chronic obstructive pulmonary disease; congestive heart failure; use of mechanical ventila-
tion within 2 weeks before surgery; sepsis; and pregnancy

Interventions

Treatment group: tidal volume $6 \mathrm{~mL} / \mathrm{kg}$ of predicted body weight, $\mathrm{PEEP} 6 \mathrm{cmH}_{2} \mathrm{O}$ and recruitment manoeuvres $(\mathrm{n}=39)$

Control group: tidal volume $10 \mathrm{~mL} / \mathrm{kg}, \mathrm{PEEP} 0 \mathrm{cmH}_{2} \mathrm{O}(\mathrm{n}=39)$

\section{Outcomes Relevant to this review}

1. Pneumonia

2. Need for postoperative non-invasive ventilation between discharge from the postoperative care unit and 7 days after the surgery

3. Need for postoperative invasive ventilation between discharge from the postoperative care unit and 7 days after the surgery

4. Length of hospital stay

\section{Others}

1. Forced vital capacity

2. Forced expiratory volume in 1 second

3. Blood gas

Notes

Funding: departmental resources

Declaration of interest: authors had no funding or conflicts of interest to disclose 
Soh 2018 (Continued)

Risk factors and points: age: $\geq 80$ years $=17 ; 70-79$ years $=13 ; 60-69$ years $=9 ; 50-59$ years $=4$; functional status totally dependent $=10$, partially dependent $=6$; weight loss $>10 \%$ in past 6 month $=7$; history of chronic obstructive pulmonary disease $=5$; general anaesthesia $=4$; impaired sensorium $=4$; history of cerebrovascular accident $=4$; blood urea nitrogen level $<2.86 \mathrm{mmol} / \mathrm{L}(<8 \mathrm{mg} / \mathrm{dL})=4 ; 7.85-10.7$ $\mathrm{mmol} / \mathrm{L}(22-30 \mathrm{mg} / \mathrm{dL})=2 ; \geq 10.7 \mathrm{mmol} / \mathrm{L}(\geq 30 \mathrm{mg} / \mathrm{dL})=3$; transfusion $>4$ units = 3; emergency surgery $=3$; steroid use for chronic condition $=3$; current smoker within 1 year $=3$; alcohol intake $>2$ drinks $/$ day in past 2 weeks $=3$

Class $1=0-15$ points; Class $2=16-25$ points; Class $3=26-40$ points; Class $3=41-55$ points; Class $5 \geq 55$ points

Volume per body weight: predicted body weight: men: 50 + 0.91 (height in $\mathrm{cm}$ - 152.4); women: $45.5+$ 0.91

(height in $\mathrm{cm}$ - 52.4)

\section{Risk of bias}

\begin{tabular}{|c|c|c|}
\hline Bias & Authors' judgement & Support for judgement \\
\hline $\begin{array}{l}\text { Random sequence genera- } \\
\text { tion (selection bias) }\end{array}$ & Low risk & Computer-generated randomization list using a permuted 2-block strategy \\
\hline $\begin{array}{l}\text { Allocation concealment } \\
\text { (selection bias) }\end{array}$ & Low risk & $\begin{array}{l}\text { Concealment of the group allocation from primary physicians, nurses, partici- } \\
\text { pants and investigators was } \\
\text { ensured by using non-transparent envelopes }\end{array}$ \\
\hline $\begin{array}{l}\text { Blinding of participants } \\
\text { and personnel (perfor- } \\
\text { mance bias) } \\
\text { All outcomes }\end{array}$ & High risk & $\begin{array}{l}\text { Envelopes opened on morning of surgery by an anaesthesiologist who was not } \\
\text { involved in the investigation but was responsible for the intraoperative partici- } \\
\text { pant care and the recording of intraoperative variables }\end{array}$ \\
\hline $\begin{array}{l}\text { Blinding of outcome as- } \\
\text { sessment (detection bias) } \\
\text { All outcomes }\end{array}$ & Low risk & Quote: "single-blinded clinical trial" \\
\hline $\begin{array}{l}\text { Incomplete outcome data } \\
\text { (attrition bias) } \\
\text { All outcomes }\end{array}$ & Low risk & No loss to follow-up \\
\hline $\begin{array}{l}\text { Selective reporting (re- } \\
\text { porting bias) }\end{array}$ & Low risk & All results provided \\
\hline Other bias & Unclear risk & $\begin{array}{l}\text { Participants characteristics similar between the groups except that partici- } \\
\text { pants in the protective group were significantly older than those in the con- } \\
\text { ventional group }\end{array}$ \\
\hline
\end{tabular}

\section{Sundar 2011}

\section{Methods}

RCT with parallel groups

Approved by the institutional review board and informed consents obtained from participants or from their nearest relatives

Site: Beth Israel Deaconess Medical Center, Boston, MA, USA

Setting: hospital

Dates of data collection: September 2007 to July 2009 


Participants 149 participants undergoing elective cardiac surgery
Exclusion criteria: emergent, non-scheduled surgery, cardiogenic shock (preoperative inotropic or in-
tra-aortic balloon support), pre-existing pulmonary disease (significant obstructive or restrictive lung
disease), active infection (treated with antibiotics) and need for single lung ventilation during the pro-
cedure

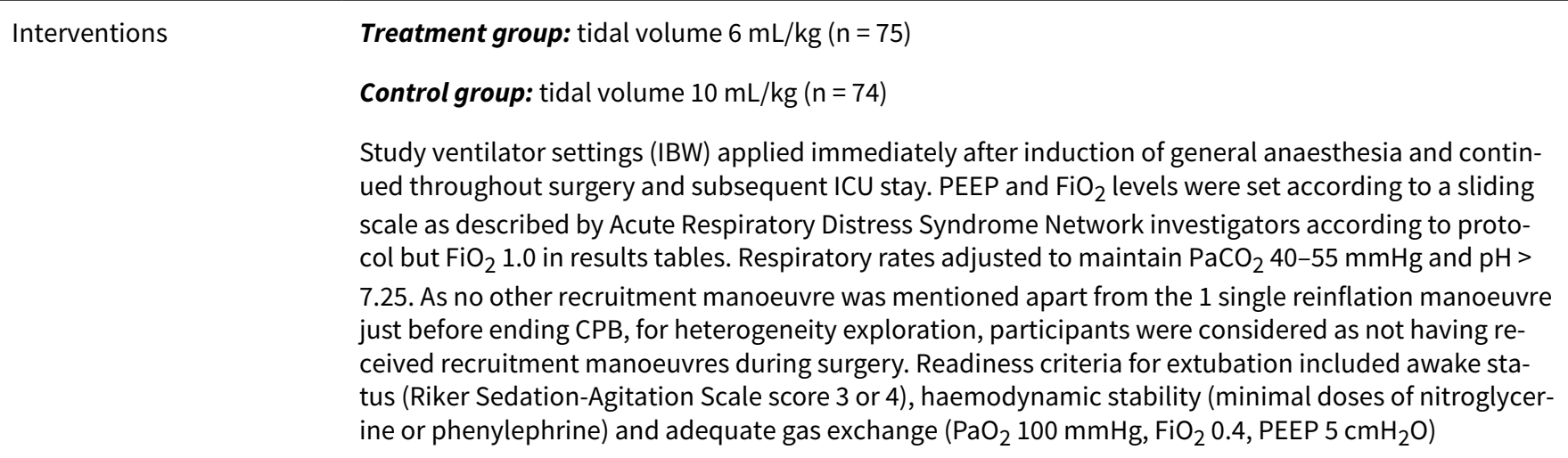

Relevant to this review
$\begin{aligned} & \text { Outcomes Invasive ventilatory support (rate of reintubation) } \\ & \text { 2. ICU length of stay } \\ & \text { 3. Hospital length of stay } \\ & \text { 4. Mortality at } 28 \text { days }\end{aligned}$

\section{Others}

1. Ventilation time

Notes
Funding: support provided solely from institutional or departmental (or both) sources
Declaration of interest: none mentioned
Volume per body weight: predicted body weight: men: $50+2.3$ (height in cm -60 ); women: $45.5+2.3$
(height in $\mathrm{cm}-60)$

\section{Risk of bias}

\begin{tabular}{lll}
\hline Bias & Authors' judgement & Support for judgement \\
\hline $\begin{array}{l}\text { Random sequence genera- } \\
\text { tion (selection bias) }\end{array}$ & Low risk & $\begin{array}{l}\text { Quote: "a block randomization scheme was used to allocate patients to one of } \\
\text { two experimental groups." }\end{array}$ \\
\hline $\begin{array}{l}\text { Allocation concealment } \\
\text { (selection bias) }\end{array}$ & Unclear risk & Not mentioned \\
\hline $\begin{array}{l}\text { Blinding of participants } \\
\begin{array}{l}\text { and personnel (perfor- } \\
\text { mance bias) }\end{array}\end{array}$ & Unclear risk & Not mentioned \\
All outcomes & \\
\hline
\end{tabular}

Blinding of outcome as- Low risk sessment (detection bias) All outcomes

\begin{abstract}
Data collected on ventilator settings, variables of gas exchange, lung mechanics and secondary outcome variables (hospital mortality, hospital length of stay, duration of mechanical ventilation) by observers blinded to participant allocation
\end{abstract}


Sundar 2011 (Continued)

Incomplete outcome data Low risk No loss to follow-up
(attrition bias)

All outcomes

Selective reporting (re- Low risk $\quad$ All results reported
porting bias)

\begin{tabular}{|c|c|c|}
\hline Other bias & Unclear risk & $\begin{array}{l}\text { No commercial entities providing equipment or devices had a role in any as- } \\
\text { pect of this study }\end{array}$ \\
\hline
\end{tabular}

Groups well balanced except for a higher incidence of postoperative complete heart block after surgery in the high volume group ( 7 vs 0 )

Not intention-to-treat. Quote: "difficult intubation off study protocol $(n=1)$ "

Treschan 2012

\begin{tabular}{|c|c|}
\hline \multirow[t]{6}{*}{ Methods } & RCT with parallel groups \\
\hline & $\begin{array}{l}\text { Approved by the local ethics committee (Ethics Committee of the Medical Faculty, Heinrich-Heine-Uni- } \\
\text { versity Düsseldorf, Germany, study number } 2974 \text { and informed consents obtained }\end{array}$ \\
\hline & Site: Dűsseldorf University Hospital, Dűsseldorf, Germany \\
\hline & Setting: university hospital \\
\hline & Dates of data collection: over 2-year period \\
\hline & ClinicalTrials.gov: NCT00795964 \\
\hline Participants & $\begin{array}{l}101 \text { participants aged } \geq 50 \text { years, ASA } \geq I \text {, scheduled for an upper abdominal surgery duration of } \\
\text { surgery } \geq 3 \text { hours }\end{array}$ \\
\hline \multirow[t]{6}{*}{ Interventions } & Treatment group: tidal volume $6 \mathrm{~mL} / \mathrm{kg}(\mathrm{IBW})(\mathrm{n}=50)$ \\
\hline & Control group: tidal volume 12 mL/kg (IBW) $(n=51)$ \\
\hline & $\begin{array}{l}\text { Initial breathing rate } 14 / \mathrm{min} \text { (low tidal volume) or } 7 / \mathrm{min} \text { (high tidal volume) was subsequently adjust- } \\
\text { ed to maintain end-tidal } \mathrm{PCO}_{2} 4.6-5.4 \mathrm{kPa}(35-40 \mathrm{mmHg} \text { ). Other ventilator settings identical in both }\end{array}$ \\
\hline & groups, including an initial fresh gas flow of $10 \mathrm{~L} / \mathrm{min}$ with a $\mathrm{FiO}_{2} 1.0$, PEEP $5 \mathrm{cmH}_{2} \mathrm{O}$ and inspiratory/ex- \\
\hline & $\begin{array}{l}\text { piratory ratio } 1: 2 \text {. The } \mathrm{FiO}_{2} \text { was reduced to } 0.5 \text { shortly after intubation. If deemed necessary by the at- } \\
\text { tending physician, the } \mathrm{FiO}_{2} \text { or } \mathrm{PEEP} \text { was increased to maintain } \mathrm{PaO}_{2} \text { within } 20 \% \text { of preoperative values }\end{array}$ \\
\hline & or $\mathrm{SaO}_{2} \geq 95 \%$. All participants received lung expansion manoeuvre consisting of 3 manual bag ventila- \\
\hline
\end{tabular}

\section{Outcomes}

\section{Relevant to this review}

1. Pneumonia

2. Invasive ventilatory support

3. ICU length of stay

4. Hospital length of stay

5. Mortality at 30 days (in hospital, mean days 30 and 25)

6. Pneumothorax

\section{Others}

1. Time weighted means of forced vital capacity and forced expiratory volume in 1 second 
Treschan 2012 (Continued)

\section{Oxygenation}

Notes Funding: supported by institutional support, Department of Anaesthesiology, Düsseldorf University Hospital

Declaration of interest: one author (TAT) had received a postgraduate stipend from Novartis-Stiftung für therapeutische Forschung.

Volume per body weight: predicted body weight: men: $50.0+0.91 \times($ height in $\mathrm{cm}-152.4)$; women: 45.5

$+0.91 \times$ (height in $\mathrm{cm}-152.4$ )

\section{Risk of bias}

\begin{tabular}{|c|c|c|}
\hline Bias & Authors' judgement & Support for judgement \\
\hline $\begin{array}{l}\text { Random sequence genera- } \\
\text { tion (selection bias) }\end{array}$ & Low risk & $\begin{array}{l}\text { Quote: "computer-generated randomization codes (permuted blocks of } 10 \text {, al- } \\
\text { location ratio 1:1)" }\end{array}$ \\
\hline $\begin{array}{l}\text { Allocation concealment } \\
\text { (selection bias) }\end{array}$ & Low risk & $\begin{array}{l}\text { Quote: "... randomization codes (permuted blocks of } 10 \text {, allocation ratio } 1: 1 \text { ) } \\
\text { were kept in sequentially numbered sealed opaque envelopes until shortly be- } \\
\text { fore induction of general anaesthesia." }\end{array}$ \\
\hline $\begin{array}{l}\text { Blinding of participants } \\
\text { and personnel (perfor- } \\
\text { mance bias) } \\
\text { All outcomes }\end{array}$ & Unclear risk & $\begin{array}{l}\text { Quote: "patients and postoperative investigators were blinded to intraoper- } \\
\text { ative group assignment; thus, all postoperative data were collected in a dou- } \\
\text { ble-blinded fashion." }\end{array}$ \\
\hline $\begin{array}{l}\text { Blinding of outcome as- } \\
\text { sessment (detection bias) } \\
\text { All outcomes }\end{array}$ & Low risk & $\begin{array}{l}\text { Quote: "patients and postoperative investigators were blinded to intraoper- } \\
\text { ative group assignment; thus, all postoperative data were collected in a dou- } \\
\text { ble-blinded fashion." }\end{array}$ \\
\hline $\begin{array}{l}\text { Incomplete outcome data } \\
\text { (attrition bias) } \\
\text { All outcomes }\end{array}$ & Low risk & No loss to follow-up \\
\hline $\begin{array}{l}\text { Selective reporting (re- } \\
\text { porting bias) }\end{array}$ & Low risk & All results reported \\
\hline Other bias & Low risk & Groups well balanced \\
\hline
\end{tabular}

Weingarten 2010

Rethods with parallel groups
Mayo Clinic Institutional Review Board approved the investigation, and each participant gave written
informed consent
Site: Saint Mary's Hospital, Rochester, MN, USA
Setting: university hospital
Dates of data collection: unspecified

Participants 40 participants aged $>65$ years undergoing major open abdominal surgery

Exclusion criteria: significant pulmonary disease with abnormalities in spirometry consistent with either obstructive or restrictive pulmonary disease, active asthma (requiring chronic bronchodilator 
Weingarten 2010 (Continued)

therapy), previous lung surgery, home oxygen therapy, significant cardiac dysfunction (left ventricular ejection fraction $<40 \%$ ), $\mathrm{BMI}>35 \mathrm{~kg} / \mathrm{m}^{2}$

Interventions

Treatment group: tidal volume $6 \mathrm{~mL} / \mathrm{kg}$ (IBW), PEEP $12 \mathrm{cmH}_{2} \mathrm{O}$ and recruitment manoeuvres (after tracheal intubation, repeated at 30 and $60 \mathrm{~min}$ after the first recruitment and hourly thereafter) $(n=20)$

Control group: tidal volume $10 \mathrm{~mL} / \mathrm{kg}$ (IBW), 0 PEEP (actual PEEP $2.5 \mathrm{cmH}_{2} \mathrm{O}$ due to the intrinsic PEEP of the mechanical ventilator) and no recruitment manoeuvres $(n=20)$

In both groups, inspiratory/expiratory time ratio $1: 2$ and $\mathrm{FiO}_{2} 0.5$ (balance nitrogen)

Relevant to this review
1. Pneumonia
2. Hospital length of stay
3. Pneumothorax (requiring chest tube placement)
4. Mortality at 30 days (information retrieved from medical records, exact duration of follow-up not men-
tioned but hospital length of stay with interquartiles from 3-20 days)

\section{Others}

1. Oxygenation

2. Respiratory system mechanics

3. Haemodynamic stability

4. Serum levels of the interleukin- 6 and -8

Notes

Funding: entirely supported by the Department of Anesthesiology, Mayo Clinic, Rochester, MN, USA

Declaration of interest: none mentioned

Volume per body weight: predicted (abstract) IBW (methods section), no further details

\section{Risk of bias}

\begin{tabular}{lll}
\hline Bias & Authors' judgement & Support for judgement \\
\hline $\begin{array}{l}\text { Random sequence genera- } \\
\text { tion (selection bias) }\end{array}$ & Low risk & $\begin{array}{l}\text { Participants randomized to 1 of 2 ventilatory management strategies using a } \\
\text { randomization schedule provided by the Division of Biostatistics }\end{array}$ \\
\hline $\begin{array}{l}\text { Allocation concealment } \\
\text { (selection bias) }\end{array}$ & Unclear risk & Not mentioned \\
\hline $\begin{array}{l}\text { Blinding of participants } \\
\text { and personnel (perfor- } \\
\text { mance bias) }\end{array}$ & Unclear risk & Not mentioned \\
All outcomes & \\
\hline $\begin{array}{l}\text { Blinding of outcome as- } \\
\text { sessment (detection bias) } \\
\text { All outcomes }\end{array}$ & Unclear risk & Not mentioned \\
\hline $\begin{array}{l}\text { Incomplete outcome data } \\
\begin{array}{l}\text { (attrition bias) } \\
\text { All outcomes }\end{array}\end{array}$ & Low risk & No loss to follow-up \\
\hline $\begin{array}{l}\text { Selective reporting (re- } \\
\text { porting bias) }\end{array}$ & Low risk & All results provided \\
\hline
\end{tabular}


Weingarten 2010 (Continued)

Other bias Unclear risk Quote: "patient characteristics and preoperative comorbidities were similar between the groups, with the

exception that more patients in the low tidal volume group had documented coronary artery disease $(P$ value $=0.044) . "$

Xiong 2016

Rethods with parallel groups
Approved by the ethics committee
Informed consents obtained
Site: First Affiliated Hospital of Chongqing Medical University, China
Setting: university hospital
Dates of data collection: unspecified

Participants

60 ASA I or II participants aged $\geq 40$ years undergoing elective spine surgery in the prone position for $\geq 3$ hours and with a risk of complications score $\geq 26$

Exclusion criteria: receiving mechanical ventilation 2 weeks before surgery; $\mathrm{BMI} \geq 35 \mathrm{~kg} / \mathrm{m}^{2}$; acute infection or sepsis 2 weeks before surgery; history of chronic obstructive pulmonary disease, thoracic or emergency surgery, progressive neuromuscular disease, acute lung injury or ARDS; need prolonged mechanical ventilation after surgery; poorly controlled hypertension; drug allergy; nausea and vomiting; history of psychological or neurological disease; or receiving chemotherapy or radiotherapy

Interventions Treatment group: tidal volume $6 \mathrm{~mL} / \mathrm{kg}$, PEEP $5 \mathrm{cmH}_{2} \mathrm{O}$ and recruitment manoeuvres every $30 \mathrm{~min}(\mathrm{n}=$ 30)

Control group: tidal volume $10 \mathrm{~mL} / \mathrm{kg}(\mathrm{n}=30)$

\section{Outcomes}

\section{Relevant to this review}

1. Pneumonia (clinical pulmonary infection score)

\section{Others}

1. Arterial blood gas

2. $\mathrm{PaO}_{2} / \mathrm{FiO}_{2}$ ratio

3. Peak and plateau airway pressures

4. Haemodynamic variables

5. White blood cells and percentage of neutrophils

6. C-reactive protein

7. Pulmonary complication risk score

8. Duration of mechanical ventilation

9. Pain scores

Notes

Funding: Ministry of Health, the National Key Laboratory of Clinical Specialties (Finance and Social Sciences (2011) No. 170); Chongqing Municipal Medical Key Discipline Project (Chongqing Wei Science and Education (2007) 2); Chongqing Municipal Health Bureau of Medical Science Key Project (2012-018) Health Bureau Medical Research Project (2012-1-018)

Declaration of interest: none mentioned

Email sent to authors to request the number of participants who were diagnosed as having a pneumonia after surgery 17 June 2017. No reply received 
Xiong 2016 (Continued)

Volume per body weight: predicted body weight; men: $50+0.91 \times$ (height in $\mathrm{cm}-152.4$ ); women: $45.5+$ $0.91 \times$ (height in $\mathrm{cm}-152.4$ )

\section{Risk of bias}

\begin{tabular}{lll}
\hline Bias & Authors' judgement & Support for judgement \\
\hline $\begin{array}{l}\text { Random sequence genera- } \\
\text { tion (selection bias) }\end{array}$ & Unclear risk & Quote: "randomized" \\
\hline $\begin{array}{l}\text { Allocation concealment } \\
\text { (selection bias) }\end{array}$ & Unclear risk & Not mentioned \\
\hline $\begin{array}{l}\text { Blinding of participants } \\
\text { and personnel (perfor- } \\
\text { mance bias) }\end{array}$ & Unclear risk & Not mentioned \\
$\begin{array}{l}\text { All outcomes } \\
\text { Blinding of outcome as- } \\
\text { sessment (detection bias) } \\
\text { All outcomes }\end{array}$ & Unclear risk & Not mentioned \\
\hline $\begin{array}{l}\text { Incomplete outcome data } \\
\text { (attrition bias) }\end{array}$ & Low risk & \\
$\begin{array}{l}\text { All outcomes } \\
\text { Selective reporting (re- } \\
\text { porting bias) }\end{array}$ & Low risk & No loss to follow-up \\
\hline \begin{tabular}{l} 
Other bias \\
\hline
\end{tabular} & Low risk & All results reported \\
\hline
\end{tabular}

\section{Zupancich 2005}

Rethods with parallel groups
Approved by the institutional review board and informed consents obtained
Site: Università di Torino, Ospedale S. Giovanni Battista, Turin, Italy
Setting: university hospital
Dates of data collection: not reported

Participants participants undergoing elective coronary artery bypass graft
Exclusion criteria: presence of cardiogenic pulmonary oedema, emergency or urgent cases, pre-exist-
ing chronic obstructive pulmonary disease, smoking history, major chest wall abnormalities and enrol-
ment in other studies

Interventions

Treatment group: tidal volume $8 \mathrm{~mL} / \mathrm{kg}$ and PEEP $10 \mathrm{cmH}_{2} \mathrm{O}$ after CPB disconnection $(\mathrm{n}=20)$

Control group: tidal volume $10-12 \mathrm{~mL} / \mathrm{kg}$ and PEEP 2-3 $\mathrm{cmH}_{2} \mathrm{O}$ after CPB disconnection $(\mathrm{n}=20)$

In both ventilatory strategies, $\mathrm{FiO}_{2} 0.5$, inspiratory/expiratory ratio $1: 2$ and respiratory rate $12-15$

breaths/min 
Zupancich 2005 (Continued)

1. Death (period of follow-up unspecified)

\section{Others}

1. Interleukin-6 and -8

\begin{tabular}{|c|c|}
\hline \multirow[t]{3}{*}{ Notes } & $\begin{array}{l}\text { Funding: supported by a grant from the Italian Minister of University and Research (02-02548) and from } \\
\text { the National Research Council (99-9854) }\end{array}$ \\
\hline & Declaration of interest: none mentioned \\
\hline & Volume per body weight: measured body weight \\
\hline
\end{tabular}

\section{Risk of bias}

\begin{tabular}{|c|c|c|}
\hline Bias & Authors' judgement & Support for judgement \\
\hline $\begin{array}{l}\text { Random sequence genera- } \\
\text { tion (selection bias) }\end{array}$ & Unclear risk & Quote: "randomly assigned" \\
\hline $\begin{array}{l}\text { Allocation concealment } \\
\text { (selection bias) }\end{array}$ & Unclear risk & Not mentioned \\
\hline $\begin{array}{l}\text { Blinding of participants } \\
\text { and personnel (perfor- } \\
\text { mance bias) } \\
\text { All outcomes }\end{array}$ & Unclear risk & Not mentioned \\
\hline $\begin{array}{l}\text { Blinding of outcome as- } \\
\text { sessment (detection bias) } \\
\text { All outcomes }\end{array}$ & Unclear risk & Not mentioned \\
\hline $\begin{array}{l}\text { Incomplete outcome data } \\
\text { (attrition bias) } \\
\text { All outcomes }\end{array}$ & Low risk & $\begin{array}{l}\text { Quote: "protocol withdrawal occurred with any of the following a priori con- } \\
\text { ditions: need for levels of dobutamine or dopamine of greater than } 5 \mathrm{mcg} / \mathrm{kg} / \\
\text { min, haemodynamically unstable condition with positive end-expiratory pres- } \\
\text { sure, or major cardiac arrhythmia." but "no patients had to be excluded from } \\
\text { the study." }\end{array}$ \\
\hline $\begin{array}{l}\text { Selective reporting (re- } \\
\text { porting bias) }\end{array}$ & Low risk & All results provided \\
\hline Other bias & Low risk & Groups well balanced \\
\hline
\end{tabular}

ARDS: adult respiratory distress syndrome; ASA: American Anesthesiologists Society physical status classification; BMI: body mass index; $\mathrm{cm}$ : centimetre; CPB: cardiopulmonary bypass; $\mathrm{CmH}_{2} \mathrm{O}$ = centimetres of water; dL: decilitre; $\mathrm{FiO}_{2}$ : inspired fraction of oxygen; IBW: ideal body weight; ICU: intensive care unit; $\mathrm{kg} / \mathrm{m}^{2}$ : kilogram per square metre of body surface area; $\mathrm{kPa}$ : kiloPascal; min: minute; mg: milligram; $\mathrm{mL} / \mathrm{kg}$ : millilitres per kilogram of body weight; $\mathrm{mmHg}$ : millimetres of mercury; $\mathrm{mmol}_{\text {: }}$ millimoles; $\mathrm{n}$ : number of participants; PaO ${ }_{2}$ : arterial oxygen partial pressure; PEEP: positive end-expiratory pressure; $\mathrm{PaCO}_{2}$ : arterial carbon dioxide partial pressure; $\mathrm{pH}$ : hydrogen ion concentration; $\mathrm{RCT}$ : randomized controlled trial; $\mathrm{SaO}_{2}$ : oxygen saturation measured by pulse oximetry; SD: standard deviation.

\section{Characteristics of excluded studies [ordered by study ID]}

\begin{tabular}{ll}
\hline Study & Reason for exclusion \\
\hline Akca 2013 & Different intervention; all participants ventilated with tidal volumes of 8-10 mL/kg of body weight \\
\hline Arora 2017 & No outcome of interest measured \\
\hline \hline
\end{tabular}

Intraoperative use of low volume ventilation to decrease postoperative mortality, mechanical ventilation, lengths of stay and lung injury 


\begin{tabular}{|c|c|}
\hline Study & Reason for exclusion \\
\hline Baki 2014 & No outcome of interest measured \\
\hline Blum 2013 & $\begin{array}{l}\text { Different intervention; intervention group received tidal volumes of ideal body weight of } 7.19 \mathrm{~mL} / \\
\mathrm{kg} \text { vs } 7.97 \mathrm{~mL} / \mathrm{kg} \text { of body weight }\end{array}$ \\
\hline Cai 2007 & No outcome of interest measured \\
\hline Clarke 1998 & No outcome of interest measured \\
\hline Cui 2015 & No outcome of interest measured \\
\hline Determann 2010 & Different population: people from a critical care unit \\
\hline Ding 2016 & $\begin{array}{l}\text { Different intervention; both groups ventilated with low tidal volumes, i.e. } 8 \mathrm{~mL} / \mathrm{kg} \text { vs } 6 \mathrm{~mL} / \mathrm{kg} \text { ideal } \\
\text { body weight }\end{array}$ \\
\hline Ela 2014 & No outcome of interest measured \\
\hline Ferrando 2015 & Different intervention; all participants ventilated with tidal volume $\leq 8 \mathrm{~mL} / \mathrm{kg}$ \\
\hline Gajic 2004 & Not an RCT: retrospective \\
\hline Gajic 2005 & Not an RCT: retrospective \\
\hline Gong 2007 & No outcome of interest measured \\
\hline Hosten 2017 & $\begin{array}{l}\text { Different intervention; pressure control vs volume control mechanical ventilation and all partici- } \\
\text { pants initially ventilated with tidal volume } 8 \mathrm{~mL} / \mathrm{kg} \text { of body weight }\end{array}$ \\
\hline Jain 2016 & $\begin{array}{l}\text { Different intervention: prospective cohort of } 60 \text { morbidly obese participants (body mass index }>35 \\
\mathrm{~kg} / \mathrm{m}^{2} \text { ), randomized into } 2 \text { groups, received positive pressure ventilation determined by ideal body } \\
\text { weight and abdominal obesity-based tidal volume calculation. In abdominal obesity group, tidal } \\
\text { volume calculated by formula weight circumference in } \mathrm{cm} \times 6.0 \mathrm{~mL} \text { and in ideal body weight group } \\
\text { by equation ideal body weight (kilogram) } \times 13 \mathrm{~mL}\end{array}$ \\
\hline Jiang 2007 & No outcome of interest measured \\
\hline Kaisers 2009 & No outcome of interest measured \\
\hline Kanaya 2011 & No outcome of interest measured \\
\hline Kang 2014 & Different study population; 1-lung ventilation \\
\hline Kim 2012 & Different study population; 1-lung ventilation \\
\hline Kokulu 2015 & No outcome of interest measured \\
\hline Lee 1990 & $\begin{array}{l}\text { Different study population: intubated people in the surgical intensive care unit randomly assigned } \\
\text { to group } 1 \text { (tidal volume } 12 \mathrm{~mL} / \mathrm{kg}, \mathrm{n}=56 \text { ) or group } 2 \text { (tidal volume } 6 \mathrm{~mL} / \mathrm{kg}, \mathrm{n}=47 \text { ) }\end{array}$ \\
\hline Lellouche 2012 & Not an RCT \\
\hline Lin 2008 & Different study population: 1-lung ventilation \\
\hline
\end{tabular}




\section{Study}

Liu 2016

Mascia 2010

Maslow 2013

Michelet 2006

Pinheiro 2010

Reis Miranda 2005a

Reis Miranda 2005b

Satoh 2012

Severgnini 2013

Shin 2010

Thornton 1998

Tugrul 1998

Tusman 1999

ly

\begin{tabular}{ll}
\hline Tweed 1991 & Quasi-randomized and cross-over trial \\
\hline Visick 1973 & Cross-over trial \\
\hline Weismann 2010 & Different population \\
\hline Wolthuis 2007 & Not an RCT: before and after an intervention to improve compliance to the new technique \\
\hline Wrigge 2000 & No outcome of interest measured \\
\hline Wrigge 2004 & No outcome of interest measured \\
\hline Wrigge 2005 & $\begin{array}{l}\text { Different study population; intervention applied at arrival in intensive care unit after surgery and } \\
\text { not intraoperatively }\end{array}$ \\
\hline Yang 2011 & Different study population; 1-lung ventilation \\
\hline Zhan-fang 2010 & Not an RCT and no outcome of interest \\
\hline
\end{tabular}

n: number of participants; PEEP: positive end-expiratory pressure; RCT: randomized controlled trial.

Characteristics of studies awaiting assessment [ordered by study ID]

\section{Asida 2015}

Methods Randomized, open-label controlled trial 
Asida 2015 (Continued)

Ethics committee: approved by the Ethics Committee of Qena Faculty of Medicine

Informed consent: written informed consents obtained

Site: Qena University Hospital, South Valley University

Setting: university hospital

Dates of data collection: 2013

Funding: university support

Registration: ACTRN12614000100695

Participants 104 ASA I or II participants aged 18-65 years scheduled for elective open urological operations done in the right or left lateral position expected to last $>2$ hours

Exclusion criteria: body mass index $>30 \mathrm{~kg} / \mathrm{m}^{2}$, history of chronic obstructive lung disease, asthma or sleep disorders, heavy smokers ( $>2$ packs/day), previous lung surgery or acute lung injury, history of neuromuscular diseases or on medications affecting the respiratory system

Interventions

Treatment group: tidal volume 5-7 mL/kg, PEEP $10 \mathrm{cmH}_{2} \mathrm{O}$ and recruitment manoeuvres $(\mathrm{n}=52)$

Control group: tidal volume $10-12 \mathrm{~mL} / \mathrm{kg}, 0$ PEEP and no recruitment manoeuvres $(n=52)$

Outcomes

\section{Relevant to this review}

1. Length of hospital stay (32 (SD 3) vs 33 (SD 4) hours)

\section{Others}

1. Lung function tests

2. Atelectasis (radiological assessment)

3. Cough

4. Fever

5. Dyspnoea

6. Pain scores

Notes

Contact information: salasida59@gmail.com (S.M. Asida), mohamad_badawy@yahoo.com (M.Sh. Badawy)

Conflict of interest: the authors declared no conflict of interest to this study

DOI: 10.1016/j.egja.2015.02.001

Volume per body weight: men: weight in $\mathrm{kg}=50+0.91 \times$ (height in $\mathrm{cm}-152.4)$; women: weight in $\mathrm{kg}=45.5+0.91 \times($ height in $\mathrm{cm}-152.4)$

Ethics committee: approved by the Institutional Review Board

Informed consent: written informed consents obtained

Site: Umraniye Education and Research Hospital, Istanbul, Turkey

Setting: university hospital

Dates of data collection: January to November 2011 
Haliloglu 2017 (Continued)

Registration: unspecified

Interventions

Treatment group: tidal volume $6 \mathrm{~mL} / \mathrm{kg}$, PEEP $8 \mathrm{cmH}_{2} \mathrm{O}(\mathrm{n}=24)$

Control group: tidal volume $10 \mathrm{~mL} / \mathrm{kg}, \mathrm{PEEP} 0 \mathrm{cmH}_{2} \mathrm{O}(\mathrm{n}=20)$

Outcomes Relevant to this review

1. No outcome of interest measured

\section{Others}

1. Lung function tests

2. Atelectasis (radiological assessment)

3. Pain scores

4. Analgesic requirement

\section{Notes}

Contact information: Beliz Bilgili, Fevzi Cakmak Mah, Mimar Sinan Cad. No. 4134000 Ust Kaynarca, TR-34899 Istanbul (Turkey)

Email belizbilgili@gmail.com

Conflict of interest: none

DOI: $10.1159 / 000484693$

Volume per body weight: ideal body weight, no further details

Moussa 2003

\begin{tabular}{ll}
\hline Methods & Randomized controlled trial \\
\hline Participants & 20 adults undergoing an elective coronary artery bypass procedure \\
\hline
\end{tabular}

Interventions Treatment group: tidal volume $6 \mathrm{~mL} / \mathrm{kg}, \mathrm{FiO}_{2} 1.0$ and PEEP $5 \mathrm{cmH}_{2} \mathrm{O}$

Control group: tidal volume $12 \mathrm{~mL} / \mathrm{kg}, \mathrm{FiO}_{2} 1.0$ and PEEP $5 \mathrm{cmH}_{2} \mathrm{O}$

$\begin{array}{ll}\text { Outcomes } & \text { 1. ICU length of stay } \\ \text { 2. Hospital length of stay } \\ \text { 3. Pulmonary complications (unspecified) }\end{array}$

Notes

The abstract did not contain enough information

We were unable to access the article despite the following steps:

1. attempts through the libraries of 3 different universities

2. attempt on the journal website

3. attempt to contact to the editor of the journal

4. attempt to contact the authors of the article (email and regular mail) 


\section{Randomized controlled trial}

Ethics committee: approved by the local Clinical Research Ethics Committees (2014)

Informed consent: written informed consents obtained

Site: Renmin Hospital of Wuhan University, Wuhan, China and Anhui Provincial Hospital of Anhui Medical University, Hefei, China

Setting: university hospital

Dates of data collection: March to December 2016

Funding: supported by grants from the National Natural Science Foundation of China (Grant no. 81671891) and

Natural Science Foundation of Hubei Province of China (Grant no. 2016CFB167)

Registration: ChiCTR-IPR-16008029

\section{Participants}

60 ASA I or II participants aged 18-70 years and with normal pulmonary function undergoing craniotomy

Exclusion criteria: bronchial infection, obstructive or restrictive lung disease, asthma, sleep apnoea syndrome, severe hypertension, cardiovascular diseases, liver or kidney dysfunction, history of second- or third-degree heart block or ischaemic heart diseases, and body mass index $>35 \mathrm{~kg} / \mathrm{m}^{2}$

Interventions

Treatment group: tidal volume $6 \mathrm{~mL} / \mathrm{kg}$ and PEEP $10 \mathrm{cmH}_{2} \mathrm{O}$

Control group: tidal volume $12 \mathrm{~mL} / \mathrm{kg}$ and 0 PEEP

\section{Outcomes}

\section{Relevant to this review}

1. No outcome of interest measured

\section{Others}

1. Haemodynamic parameters

2. Lung function index

3. Inflammatory and oxidative stress markers

4. Blood loss

Notes

Contact information: Beliz Bilgili, Fevzi Cakmak Mah, Mimar Sinan Cad. No. 4134000 Ust Kaynarca, TR-34899 Istanbul (Turkey)

Correspondence: Zhongyuan Xia; xiazhongyuan2005@aliyun.com

Conflict of interest: authors declared that there was no conflict of interest regarding the publication of this article

DOI: $10.1159 / 000484693$

Volume per body weight: unspecified method

$\mathrm{mL} / \mathrm{kg}$ : millilitres per kilogram of body weight; ASA: American Society of Anesthesiologists physical status; $\mathrm{cmH}_{2} \mathrm{O}$ : centimetres of water; PEEP: positive end-expiratory pressure; RCT: randomized controlled trial.

Characteristics of ongoing studies [ordered by study ID] 
ACTRN12614000790640

\begin{tabular}{|c|c|}
\hline Trial name or title & $\begin{array}{l}\text { A prospective randomized trial of two tidal volume ventilator strategies in patients undergoing ma- } \\
\text { jor surgery }\end{array}$ \\
\hline Methods & $\mathrm{RCT}$ \\
\hline Participants & Adults undergoing major surgery \\
\hline Interventions & $\begin{array}{l}\text { Treatment group: tidal volume } 6 \mathrm{~mL} / \mathrm{kg} \text { (ideal body weight) and PEEP } 5 \mathrm{cmH}_{2} \mathrm{O} \\
\text { Control group: tidal volume } 10 \mathrm{~mL} / \mathrm{kg} \text { (Ideal body weight) and PEEP } 5 \mathrm{cmH}_{2} \mathrm{O}\end{array}$ \\
\hline Outcomes & $\begin{array}{l}\text { 1. Number of participants with a postoperative pulmonary complication. Pulmonary complications } \\
\text { include pneumonia, bronchospasm, atelectasis, pulmonary congestion, pulmonary embolism, } \\
\text { respiratory failure and requirements for mechanical ventilation } \\
\text { 2. Requirements for postoperative intensive care } \\
\text { 3. ICU length of stay } \\
\text { 4. Hospital stay length of stay } \\
\text { 5. 30-day mortality }\end{array}$ \\
\hline Starting date & 1 August 2014 \\
\hline Contact information & Dr Laurence Weinberg: laurence.weinberg@austin.org.au \\
\hline Notes & Recruiting (accessed 8 January 2018) \\
\hline
\end{tabular}

\section{NCT01003730}

Trial name or title The effects of different ventilator strategies on inflammation and injury in normal lungs

Methods RCT

Site: University of Medicine and Dentistry of New Jersey, Newark, NJ, USA

\begin{tabular}{ll}
\hline Participants & Adults aged 18-65 years undergoing surgery of $\geq 4$ hours in supine position \\
\hline Interventions & Treatment group: tidal volume $6 \mathrm{~mL} / \mathrm{kg}$ of predicted body weight and $\mathrm{PEEP} 3 \mathrm{cmH}_{2} \mathrm{O}$ or $10 \mathrm{cmH} \mathrm{C}_{2} \mathrm{O}$ \\
\hline Control group: tidal volume $15 \mathrm{~mL} / \mathrm{kg}$ of predicted body weight and PEEP $3 \mathrm{cmH}_{2} \mathrm{O}$ \\
\hline Starting date & 1. Mortality at 30 days \\
\hline Contact information & March 2009 \\
\hline Notes & Delphin E; Rutgers, The State University of New Jersey, New Brunswick, NJ \\
\hline
\end{tabular}

\section{NCT03157479}

$\begin{array}{ll}\text { Trial name or title } & \begin{array}{l}\text { Intraoperative protective ventilation for obese patients undergoing gynaecological laparoscopic } \\ \text { surgery (Inprove4large) }\end{array}\end{array}$


NCT03157479 (Continued)

Methods RCT

Site: Catholic University of the Sacred Heart, Rome, Italy

\begin{tabular}{ll}
\hline Participants & Adult obese (body mass index $>35 \mathrm{~kg} / \mathrm{m}^{2}$ ) women undergoing laparoscopic surgery \\
\hline Interventions & Treatment group: tidal volume $6-7 \mathrm{~mL} / \mathrm{kg}$ of predicted body weight and recruitment manoeuvres \\
& Control group: tidal volume $10 \mathrm{~mL} / \mathrm{kg}$ of predicted body weight and PEEP $5 \mathrm{cmH}_{2} \mathrm{O}$ \\
\hline
\end{tabular}

Outcomes 1. Pneumonia

\begin{tabular}{ll}
\hline Starting date & 1 May 2017 \\
\hline Contact information & Domenico Luca Grieco, MD; Email: dlgrieco@ymail.com \\
\hline Notes & Recruiting, last update posted 16 June 2017 (accessed 8 January 2018)
\end{tabular}

$\mathrm{CmH}_{2} \mathrm{O}$ : centimetres of water; ICU: intensive care unit; $\mathrm{kg} / \mathrm{m}^{2}$ : kilogram per square metre of body surface area; $\mathrm{mL} / \mathrm{kg}: \mathrm{millilitres} \mathrm{per}$ kilogram of body weight; PEEP: positive end-expiratory pressure; RCT: randomized controlled trial.

\section{DATA AND ANALYSES}

Comparison 1. Low versus high tidal volume

\begin{tabular}{|c|c|c|c|c|}
\hline Outcome or subgroup title & No. of studies & $\begin{array}{l}\text { No. of partici- } \\
\text { pants }\end{array}$ & Statistical method & Effect size \\
\hline 1 Mortality within 30 days & 12 & 1207 & $\begin{array}{l}\text { Risk Ratio (M-H, Fixed, 95\% } \\
\mathrm{Cl})\end{array}$ & $0.80[0.42,1.53]$ \\
\hline 2 Pneumonia & 7 & 778 & $\begin{array}{l}\text { Risk Ratio (M-H, Fixed, 95\% } \\
\mathrm{Cl})\end{array}$ & $0.45[0.25,0.82]$ \\
\hline $\begin{array}{l}3 \text { Need for postoperative non-inva- } \\
\text { sive ventilation }\end{array}$ & 3 & 506 & $\begin{array}{l}\text { Risk Ratio (M-H, Fixed, 95\% } \\
\mathrm{Cl})\end{array}$ & $0.31[0.15,0.64]$ \\
\hline $\begin{array}{l}4 \text { Need for postoperative invasive } \\
\text { ventilation }\end{array}$ & 11 & 957 & $\begin{array}{l}\text { Risk Ratio (M-H, Fixed, 95\% } \\
\mathrm{Cl})\end{array}$ & $0.33[0.14,0.77]$ \\
\hline $\begin{array}{l}5 \text { Intensive care unit length of stay } \\
\text { (days) }\end{array}$ & 5 & 898 & $\begin{array}{l}\text { Std. Mean Difference (Ran- } \\
\text { dom, } 95 \% \mathrm{Cl} \text { ) }\end{array}$ & $-0.06[-0.22,0.10]$ \\
\hline $\begin{array}{l}6 \text { Hospital length of stay divided in } \\
\text { subgroups according to positive end- } \\
\text { expiratory pressure (PEEP) use (days) }\end{array}$ & 14 & 1298 & $\begin{array}{l}\text { Std. Mean Difference (Ran- } \\
\text { dom, } 95 \% \mathrm{Cl} \text { ) }\end{array}$ & $-0.15[-0.29,-0.00]$ \\
\hline 6.1 PEEP used for both groups & 8 & 537 & $\begin{array}{l}\text { Std. Mean Difference (Ran- } \\
\text { dom, } 95 \% \mathrm{Cl} \text { ) }\end{array}$ & $-0.08[-0.33,0.18]$ \\
\hline $\begin{array}{l}6.2 \text { PEEP used for low tidal volume } \\
\text { group only }\end{array}$ & 7 & 761 & $\begin{array}{l}\text { Std. Mean Difference (Ran- } \\
\text { dom, } 95 \% \mathrm{Cl} \text { ) }\end{array}$ & $-0.23[-0.38,-0.08]$ \\
\hline
\end{tabular}

Intraoperative use of low volume ventilation to decrease postoperative mortality, mechanical ventilation, lengths of stay and lung injury 


\begin{tabular}{|c|c|c|c|c|}
\hline Outcome or subgroup title & No. of studies & $\begin{array}{l}\text { No. of partici- } \\
\text { pants }\end{array}$ & Statistical method & Effect size \\
\hline $\begin{array}{l}7 \text { Hospital length of stay divided in } \\
\text { subgroups according to recruitment } \\
\text { manoeuvres or not (days) }\end{array}$ & 14 & 1298 & $\begin{array}{l}\text { Std. Mean Difference (Ran- } \\
\text { dom, } 95 \% \mathrm{Cl} \text { ) }\end{array}$ & $-0.15[-0.29,-0.00]$ \\
\hline $\begin{array}{l}\text { 7.1 Recruitment manoeuvres in low } \\
\text { tidal volume group only }\end{array}$ & 4 & 638 & $\begin{array}{l}\text { Std. Mean Difference (Ran- } \\
\text { dom, } 95 \% \mathrm{Cl} \text { ) }\end{array}$ & $-0.25[-0.41,-0.09]$ \\
\hline $\begin{array}{l}\text { 7.2 Recruitment manoeuvres in high } \\
\text { tidal volume group only }\end{array}$ & 1 & 40 & $\begin{array}{l}\text { Std. Mean Difference (Ran- } \\
\text { dom, } 95 \% \mathrm{Cl} \text { ) }\end{array}$ & $0.0[-0.62,0.62]$ \\
\hline $\begin{array}{l}7.3 \text { Recruitment manoeuvres in both } \\
\text { groups }\end{array}$ & 3 & 254 & $\begin{array}{l}\text { Std. Mean Difference (Ran- } \\
\text { dom, } 95 \% \mathrm{Cl} \text { ) }\end{array}$ & $0.16[-0.09,0.40]$ \\
\hline $\begin{array}{l}7.4 \text { No recruitment manoeuvres men- } \\
\text { tioned }\end{array}$ & 6 & 366 & $\begin{array}{l}\text { Std. Mean Difference (Ran- } \\
\text { dom, } 95 \% \mathrm{Cl} \text { ) }\end{array}$ & $-0.26[-0.50,-0.02]$ \\
\hline 8 Pneumothorax & 5 & 708 & $\begin{array}{l}\text { Risk Ratio (M-H, Fixed, 95\% } \\
\text { Cl) }\end{array}$ & $1.77[0.52,5.99]$ \\
\hline
\end{tabular}

Analysis 1.1. Comparison 1 Low versus high tidal volume, Outcome 1 Mortality within 30 days.

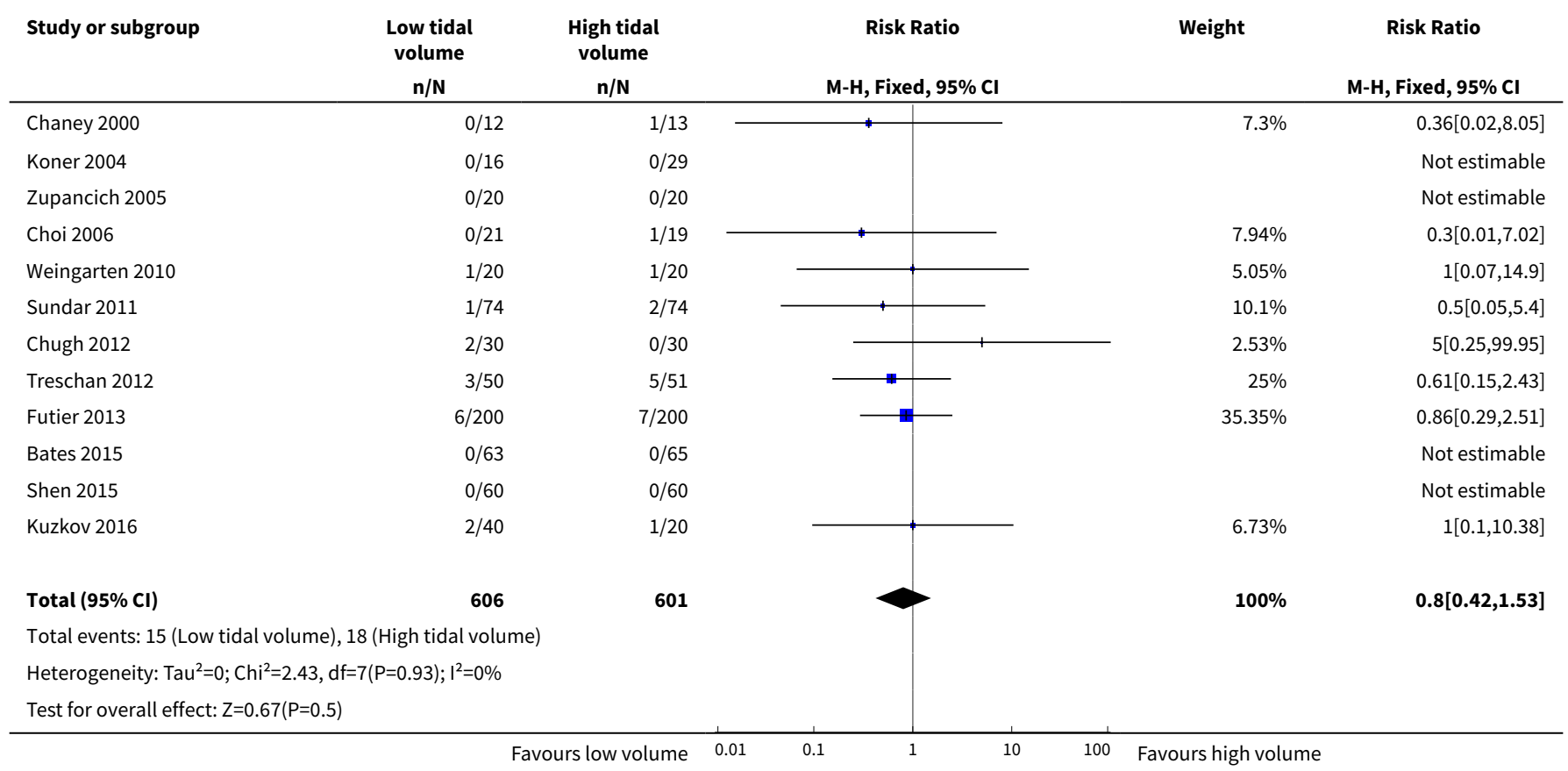


Analysis 1.2. Comparison 1 Low versus high tidal volume, Outcome 2 Pneumonia.

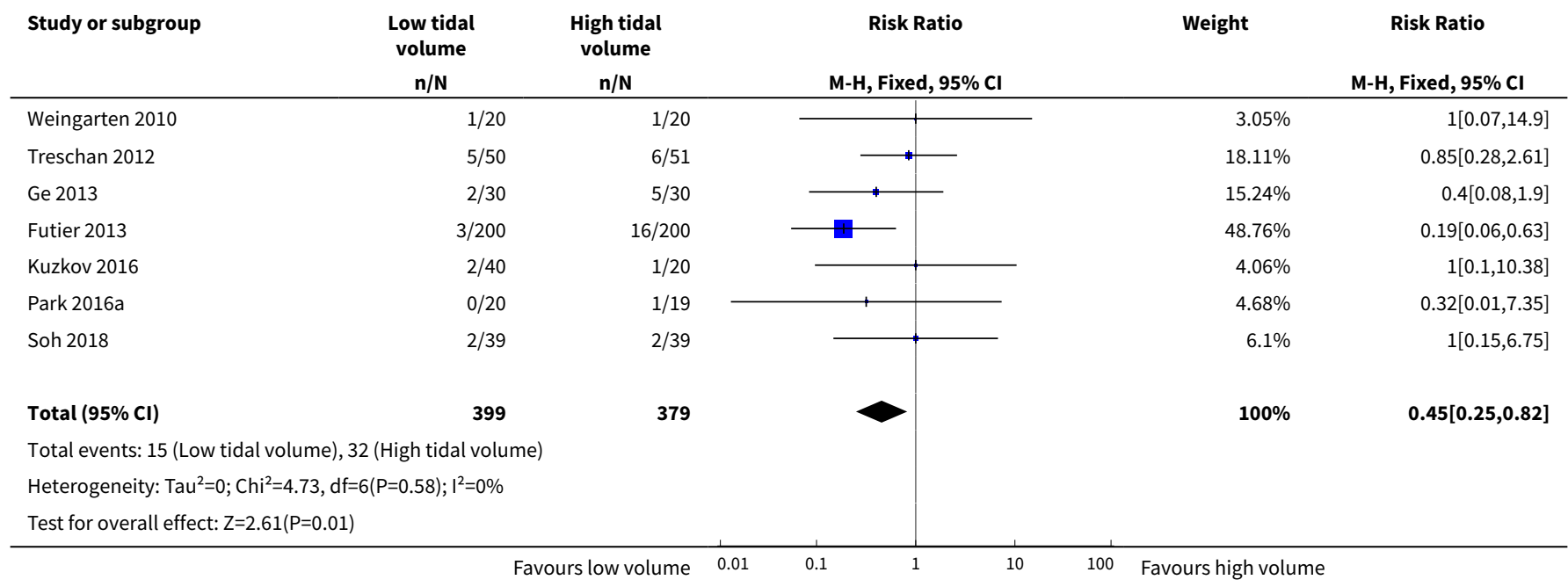

Analysis 1.3. Comparison 1 Low versus high tidal volume, Outcome 3 Need for postoperative non-invasive ventilation.

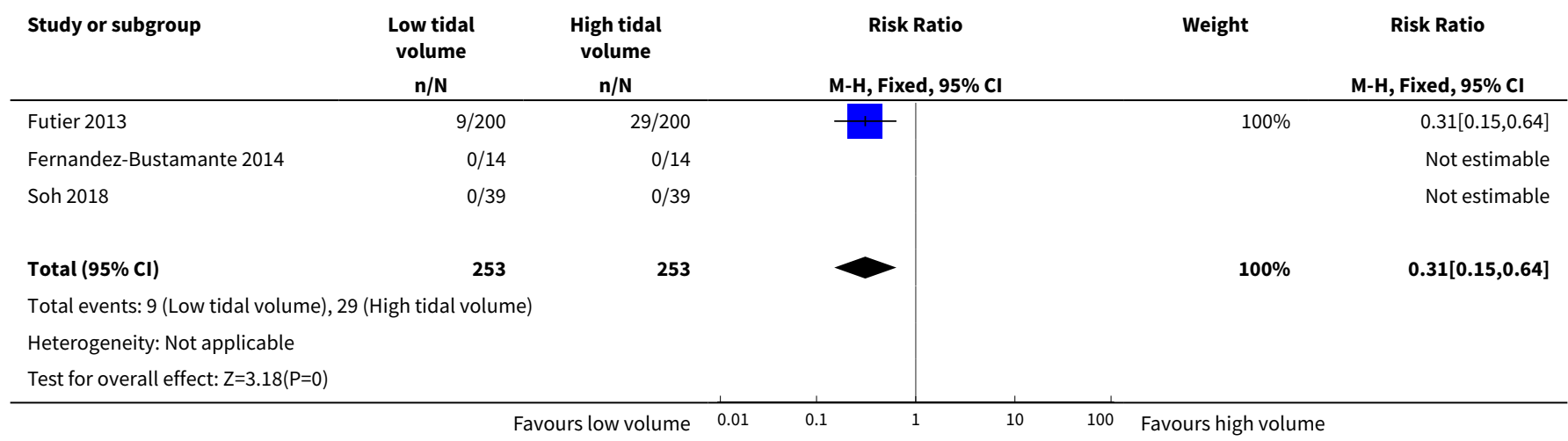

Analysis 1.4. Comparison 1 Low versus high tidal volume, Outcome 4 Need for postoperative invasive ventilation.

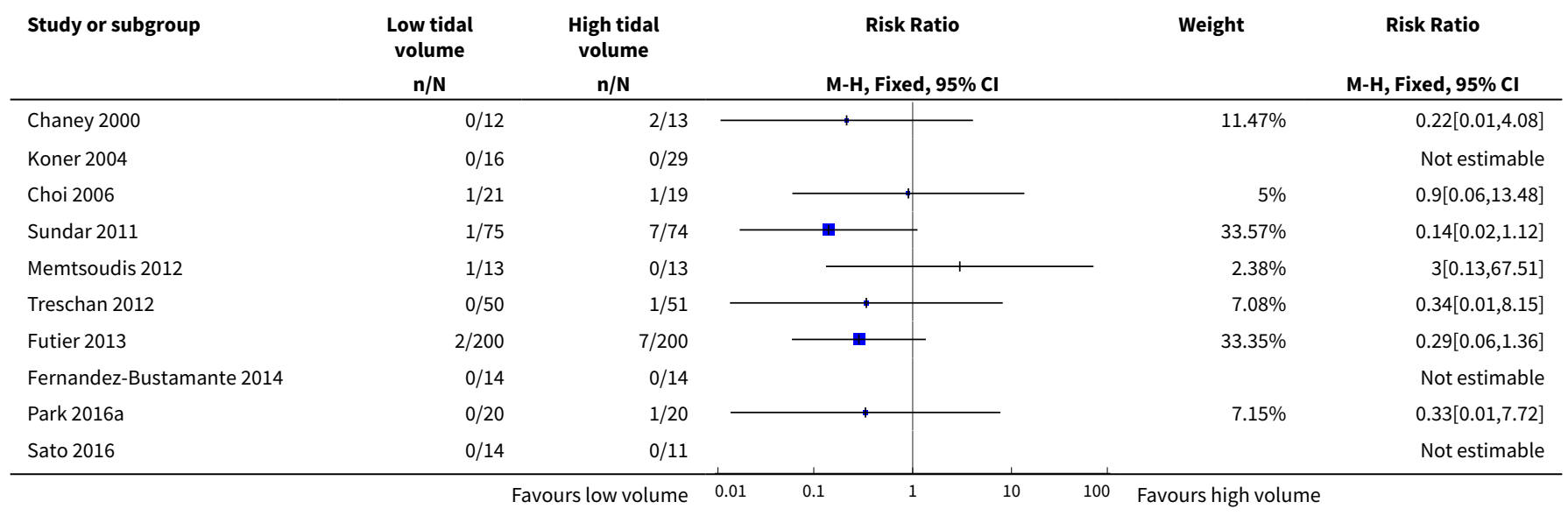




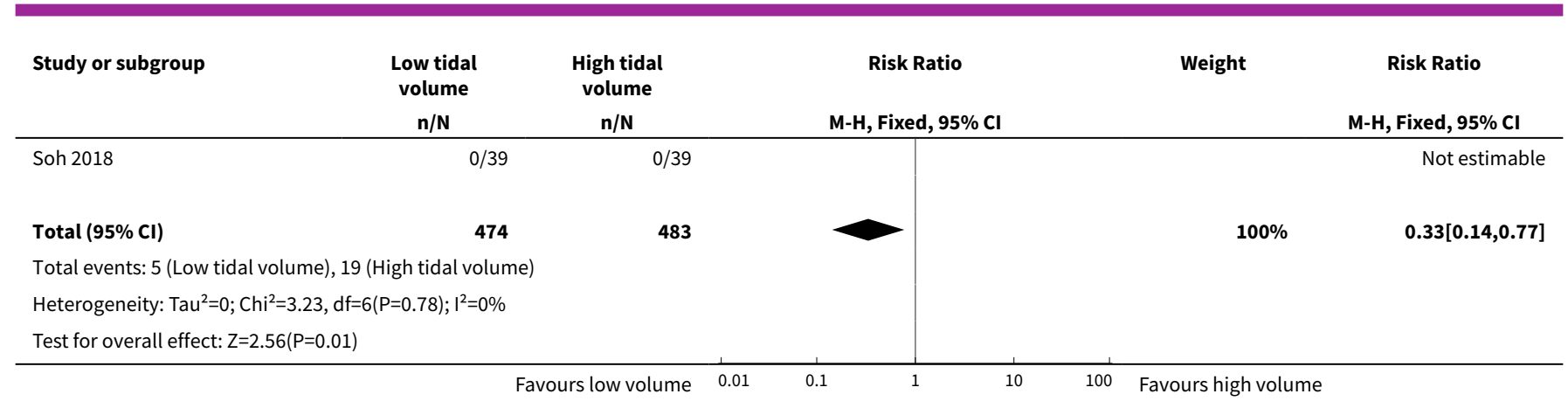

\title{
Analysis 1.5. Comparison 1 Low versus high tidal volume, Outcome 5 Intensive care unit length of stay (days).
}

\begin{tabular}{|c|c|c|c|c|c|c|}
\hline Study or subgroup & $\begin{array}{c}\text { Low tidal } \\
\text { volume } \\
\mathrm{N}\end{array}$ & $\begin{array}{l}\text { High tidal } \\
\text { volume } \\
\text { N }\end{array}$ & $\begin{array}{l}\text { Std. Mean } \\
\text { Difference } \\
\quad \text { (SE) }\end{array}$ & $\begin{array}{l}\text { Std. Mean Difference } \\
\text { IV, Random, } 95 \% \mathrm{CI}\end{array}$ & Weight & $\begin{array}{l}\text { Std. Mean Difference } \\
\text { IV, Random, } 95 \% \text { CI }\end{array}$ \\
\hline Sundar 2011 & 75 & 74 & $-0.2(0.164)$ & $*$ & $17.63 \%$ & $-0.15[-0.48,0.17]$ \\
\hline Treschan 2012 & 50 & 51 & $0.3(0.2)$ & $\leftarrow$ & $13.12 \%$ & $0.3[-0.09,0.69]$ \\
\hline Futier 2013 & 200 & 200 & $-0.1(0.079)$ & $\#$ & $38.52 \%$ & $-0.05[-0.21,0.1]$ \\
\hline Bates 2015 & 63 & 65 & $-0(0.177)$ & $\rightarrow$ & $15.82 \%$ & $-0.02[-0.36,0.33]$ \\
\hline Shen 2015 & 60 & 60 & $-0.3(0.184)$ & $\rightarrow$ & $14.92 \%$ & $-0.34[-0.7,0.02]$ \\
\hline Total $(95 \% \mathrm{Cl})$ & & & & 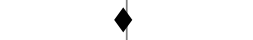 & $100 \%$ & $-0.06[-0.22,0.1]$ \\
\hline \multicolumn{7}{|c|}{ Heterogeneity: $\mathrm{Tau}^{2}=0.01 ; \mathrm{Chi}^{2}=6.01, \mathrm{df}=4(\mathrm{P}=0.2) ; \mathrm{I}^{2}=33.47 \%$} \\
\hline Test for overall effec & & & & & & \\
\hline
\end{tabular}

\begin{abstract}
Analysis 1.6. Comparison 1 Low versus high tidal volume, Outcome 6 Hospital length of stay divided in subgroups according to positive end-expiratory pressure (PEEP) use (days).
\end{abstract}

\begin{tabular}{|c|c|c|c|c|c|c|}
\hline Study or subgroup & $\begin{array}{c}\text { Low tidal } \\
\text { volume } \\
\mathrm{N} \\
\end{array}$ & $\begin{array}{c}\text { High tidal } \\
\text { volume } \\
\mathrm{N} \\
\end{array}$ & $\begin{array}{l}\text { Std. Mean } \\
\text { Difference } \\
\text { (SE) } \\
\end{array}$ & $\begin{array}{l}\text { Std. Mean Difference } \\
\text { IV, Random, 95\% CI }\end{array}$ & Weight & $\begin{array}{l}\text { Std. Mean Difference } \\
\text { IV, Random, } 95 \% \mathrm{Cl}\end{array}$ \\
\hline \multicolumn{7}{|c|}{ 1.6.1 PEEP used for both groups } \\
\hline Chaney 2000 & 12 & 12 & $-0.5(0.415)$ & $\longrightarrow$ & $2.83 \%$ & $-0.51[-1.33,0.3]$ \\
\hline Koner 2004 & 8 & 14 & $-0.6(0.461)$ & 1 & $2.34 \%$ & $-0.57[-1.47,0.34]$ \\
\hline Sundar 2011 & 75 & 74 & $-0.2(0.164)$ & + & $11.66 \%$ & $-0.23[-0.55,0.09]$ \\
\hline Fernandez-Bustamante 2014 & 14 & 14 & $0.4(0.382)$ & 1 & $3.28 \%$ & $0.41[-0.34,1.16]$ \\
\hline Bates 2015 & 63 & 65 & $-0(0.177)$ & + & $10.66 \%$ & $-0.02[-0.36,0.33]$ \\
\hline Sato 2016 & 14 & 11 & $0.3(0.406)$ & -1 & $2.94 \%$ & $0.34[-0.46,1.14]$ \\
\hline Kuzkov 2016 & 40 & 20 & $-0.6(0.279)$ & $\longrightarrow$ & $5.57 \%$ & $-0.55[-1.1,-0]$ \\
\hline Subtotal $(95 \% \mathrm{CI})$ & & & & & $48.36 \%$ & $-0.08[-0.33,0.18]$ \\
\hline \multicolumn{7}{|c|}{ Heterogeneity: $\operatorname{Tau}^{2}=0.06 ; \mathrm{Chi}^{2}=12.99, \mathrm{df}=7(\mathrm{P}=0.07) ; \mathrm{I}^{2}=46.13 \%$} \\
\hline \multicolumn{7}{|c|}{ 1.6.2 PEEP used for low tidal volume group only } \\
\hline Koner 2004 & 8 & 15 & $-0.7(0.46)$ & & $2.35 \%$ & $-0.71[-1.61,0.19]$ \\
\hline Weingarten 2010 & 20 & 20 & $-0.6(0.323)$ & 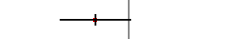 & $4.38 \%$ & $-0.59[-1.22,0.04]$ \\
\hline
\end{tabular}




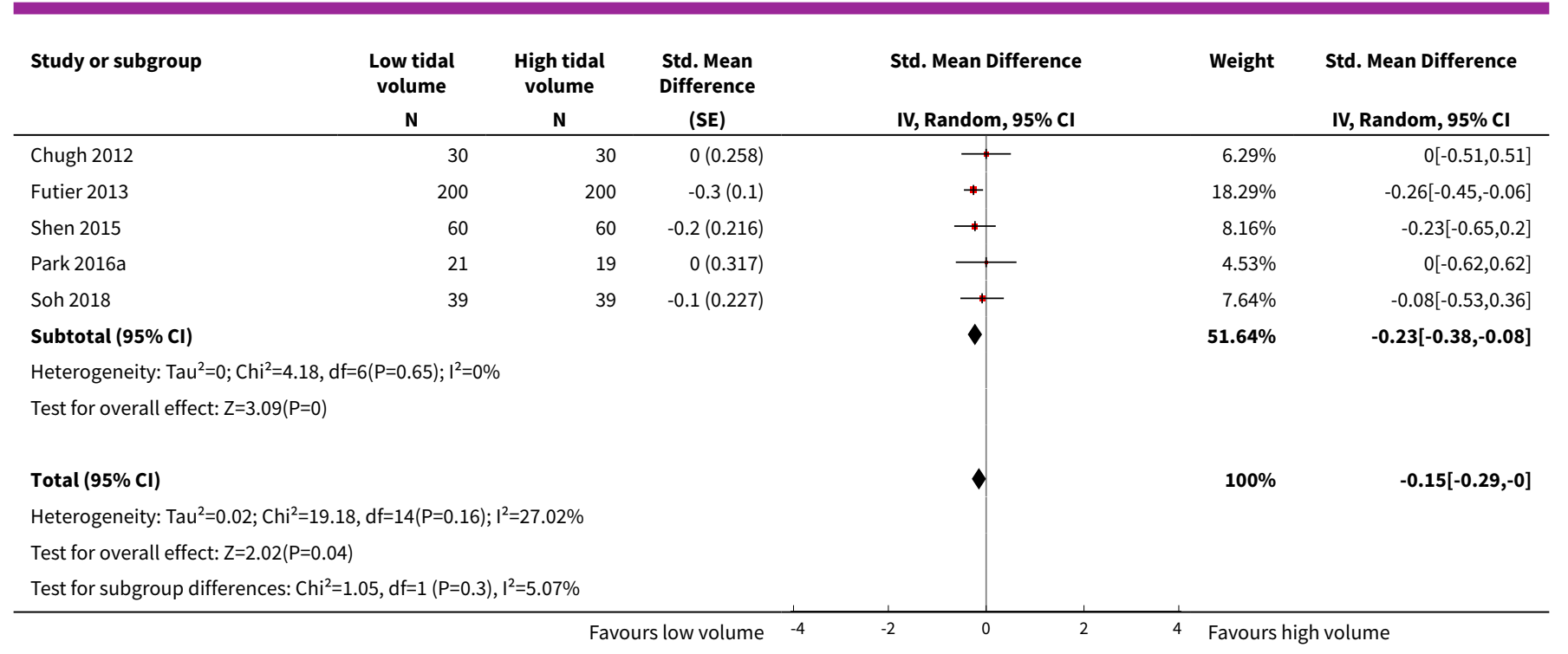

\section{Analysis 1.7. Comparison 1 Low versus high tidal volume, Outcome 7 Hospital length of stay divided in subgroups according to recruitment manoeuvres or not (days).}

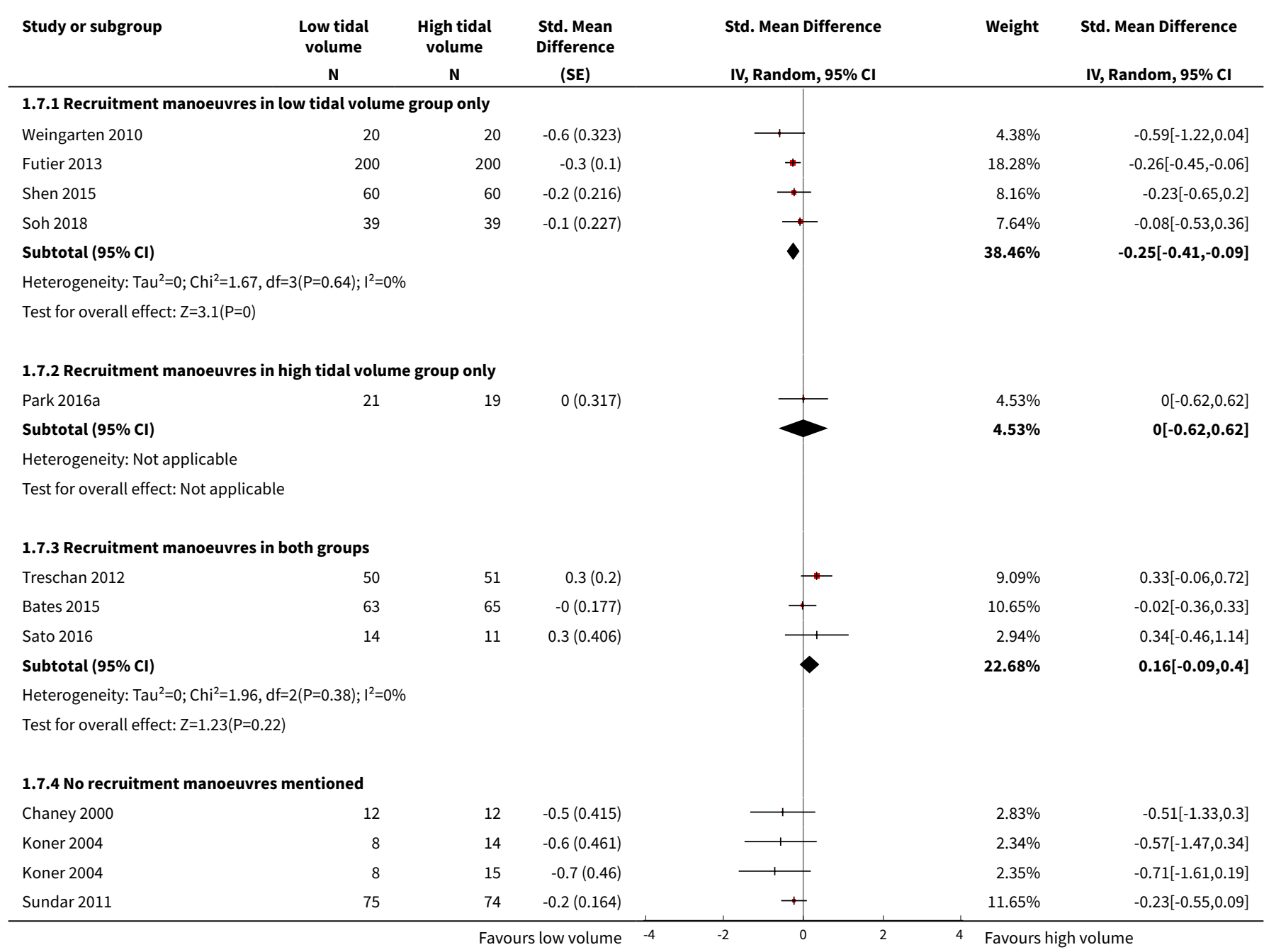




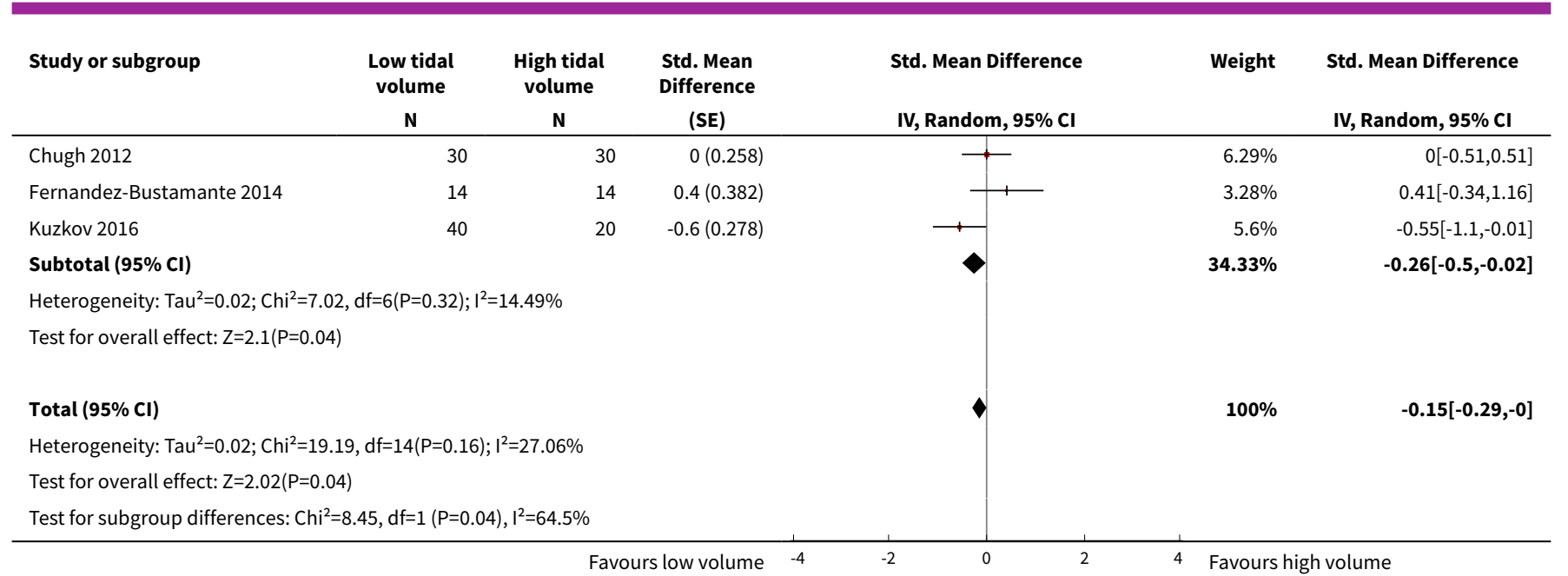

Analysis 1.8. Comparison 1 Low versus high tidal volume, Outcome 8 Pneumothorax.

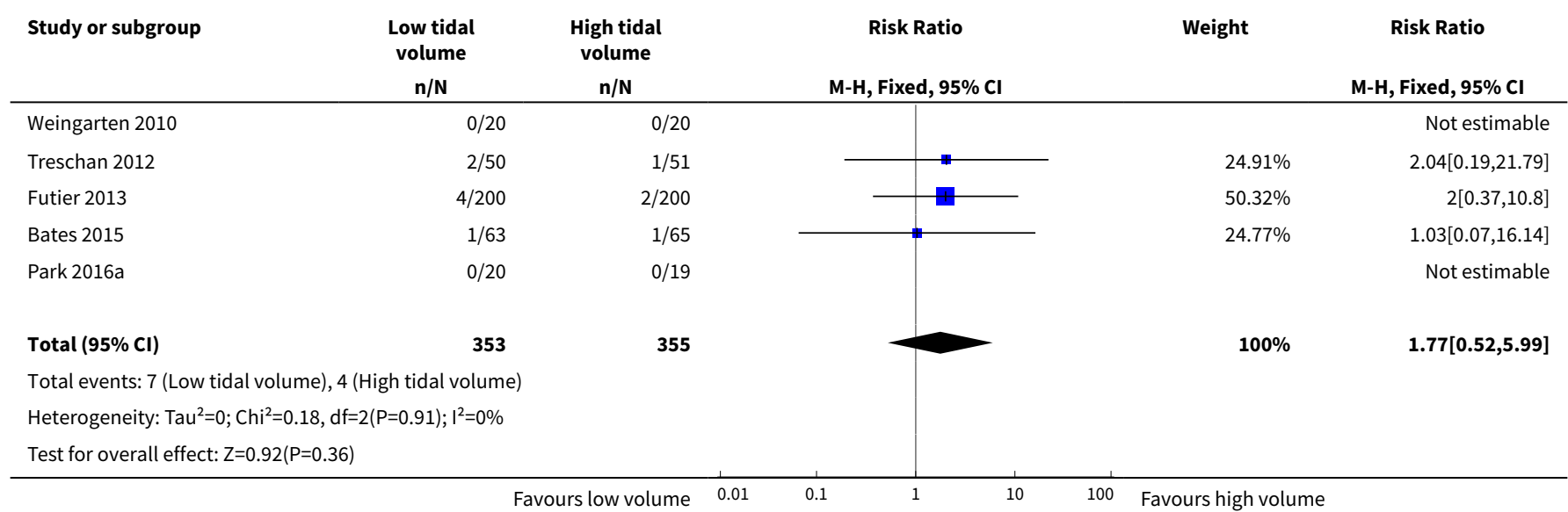

\section{ADDITIONAL TABLES}

Table 1. Diagnostic criteria for pneumonia

\begin{tabular}{lll}
\hline Study & Definition & \multicolumn{1}{c}{ Number of partici- } \\
pants
\end{tabular}

Futier 2013

Defined according to CDC criteria

400

Pneumonia was suspected upon the presence of new or progressive (or both) pulmonary infiltrates on chest $X$-ray plus $\geq 2$ of the following criteria:

1. fever $\geq 38.5^{\circ} \mathrm{C}$ or hypothermia $<36^{\circ} \mathrm{C}$

2. leukocytosis $\geq 12,000 \mathrm{WBC} / \mathrm{mm}^{3}$ or leukopenia $<4000 \mathrm{WBC} / \mathrm{mm}^{3}$

3. purulent sputum or new onset (or both) or worsening cough or dyspnoea 
Table 1. Diagnostic criteria for pneumonia (Continued)

Kuzkov $2016 \quad$ Plain chest X-ray performed as a standard procedure at 24 hours of the postoperative period in the semi-recumbent position; the films were interpreted by an independent specialist. In cases when postoperative pulmonary complications (e.g. atelectasis, pleuritis, nosocomial pneumonia, etc.) were suspected, chest X-ray or computed tomography was performed within the period of observation up to day 28 on request either in the intensive care unit or in the radiology department.

\begin{tabular}{|c|c|}
\hline Park 2016a & $\begin{array}{l}\text { Postoperative chest images were compared to the preoperative ones and in- } \\
\text { terpreted by the blinded radiologist at immediately after operation, } 1 \text { and } 2 \\
\text { days after surgery. }\end{array}$ \\
\hline \multirow[t]{2}{*}{ Shen 2015} & $\begin{array}{l}\text { Pulmonary infection defined as new or progressive exudation on chest X-ray } \\
\text { combined with } \geq 2 \text { of the following criteria: body temperature } \geq 38.5^{\circ} \mathrm{C} \text { or }<36\end{array}$ \\
\hline & $\begin{array}{l}{ }^{\circ} \mathrm{C} \text {; WBC count } \geq 12,000 / \mathrm{mm}^{3} \text { or }<4000 / \mathrm{mm}^{3} \text {; purulent sputum, coughing or } \\
\text { difficult breathing }\end{array}$ \\
\hline
\end{tabular}
terpreted by the blinded radiologist at immediately after operation, 1 and 2 0 Chest X-ray; complete blood count; symptoms including dyspnoea, cough, and the presence of secretions; and modified clinical pulmonary infection score were assessed on the day of surgery, postoperative day 1 and 3, as clinically needed, or a combination of these

Pneumonia defined as Futier 2013

\begin{tabular}{llc}
\hline Treschan 2012 & Pneumonia & 101 \\
\hline Weingarten 2010 & Pneumonia & 40 \\
\hline
\end{tabular}

CDC: Centers for Disease Control and Prevention; $\mathrm{mm}^{3}$ : cubic millilitre; WBC: white blood cells.

Table 2. Additional information on the included studies

\begin{tabular}{|c|c|c|c|c|}
\hline Study & Criteria for extubation & ICU ventilation & $\begin{array}{l}\text { Criteria for non- } \\
\text { invasive venti- } \\
\text { lation }\end{array}$ & $\begin{array}{l}\text { Criteria for in- } \\
\text { vasive ventila- } \\
\text { tion }\end{array}$ \\
\hline Bates 2015 & $\begin{array}{l}\text { Once participants were titrated down to } \\
\text { an } \mathrm{FiO}_{2} \leq 0.5 \text { and } \mathrm{PEEP} 5 \mathrm{cmH}_{2} \mathrm{O} \text {, they were } \\
\text { assessed twice daily with spontaneous } \\
\text { breathing trials. } \\
\text { Participants were considered ready for } \\
\text { extubation from a pulmonary mechanics } \\
\text { standpoint if their rapid shallow breathing } \\
\text { index was }<105 \text { for } 30 \text { minutes. }\end{array}$ & $\begin{array}{l}\text { Same parameters for the } \\
\text { first } 3 \text { after surgery if re- } \\
\text { quired }\end{array}$ & Unspecified & $\begin{array}{l}\text { All participants } \\
\text { admitted to ICU } \\
\text { and kept on me- } \\
\text { chanical venti- } \\
\text { lation through } \\
\text { an endotra- } \\
\text { cheal tube after } \\
\text { surgery }\end{array}$ \\
\hline Chaney 2000 & $\begin{array}{l}\text { Normal ICU protocol: appropriate senso- } \\
\text { rium, normothermia, haemodynamic sta- } \\
\text { bility, adequate pulmonary function }\left(\mathrm{PaO}_{2}\right. \\
\left.>60 \mathrm{mmHg} \text { with } \mathrm{FiO}_{2} 0.4\right) \text {, adequate urine } \\
\text { output and minimal chest tube output }\end{array}$ & $\begin{array}{l}\text { Same mode of ventila- } \\
\text { tion for the first hour af- } \\
\text { ter surgery, then tidal } \\
\text { volume } 8 \mathrm{~mL} / \mathrm{kg} \text {, rate } \\
10 / \mathrm{minute}, \mathrm{FiO}_{2} 1.0 \text { and } \\
\text { PEEP } 5 \mathrm{cmH}_{2} \mathrm{O} \text { for all par- } \\
\text { ticipants }\end{array}$ & Unspecified & Unspecified \\
\hline Choi 2006 & Unspecified & $\begin{array}{l}\text { If the surgical procedure } \\
\text { exceeded } 5 \text { hours, anaes- } \\
\text { thesiologists were al- }\end{array}$ & Unspecified & Unspecified \\
\hline
\end{tabular}


Table 2. Additional information on the included studies (Continued)

lowed to change the ven-

tilation strategy there-

after

\begin{tabular}{|c|c|c|c|c|}
\hline Chugh 2012 & Unspecified & Unspecified & Unspecified & Unspecified \\
\hline $\begin{array}{l}\text { Fernandez-Bus- } \\
\text { tamante } 2014\end{array}$ & Unspecified & Unspecified & Unspecified & Unspecified \\
\hline Futier 2013 & $\begin{array}{l}\text { Recovery of a spontaneous ventilation with } \\
\text { an expired tidal volume } 5-8 \mathrm{~mL} / \mathrm{kg} \text {, respi- } \\
\text { ratory rate } 12-25 \text { breaths } / \mathrm{min} \text {, absence } \\
\text { of residual neuromuscular blockade (as- } \\
\text { sessed by a } \mathrm{T} 4 / \mathrm{T} 1 \text { ratio } \geq 90 \% \text { ), peripheral } \\
\text { oxygen saturation } \geq 95 \% \text {, stable haemody- } \\
\text { namics and body temperature } \geq 36^{\circ} \mathrm{C}\end{array}$ & Unspecified & Unspecified & Unspecified \\
\hline
\end{tabular}

\begin{tabular}{lllll}
\hline Ge 2013 & Unspecified & Unspecified & Unspecified & Unspecified \\
\hline Koner 2004 & Unspecified & Unspecified & Unspecified & Unspecified \\
\hline Kuzkov 2016 & The criteria for discontinuation of respira- & Unspecified & Unspecified & Unspecified
\end{tabular}

tory support

were as follows: the ability to tolerate 30

minutes of spontaneous breathing trial via

the pressure support ventilation with pres-

sure support level of $6-8 \mathrm{cmH}_{2} \mathrm{O}, \mathrm{PaO}_{2} /$

$\mathrm{FiO}_{2}>200 \mathrm{mmHg}$, spontaneous minute

volume $<10 \mathrm{~L} / \mathrm{min}$, and respiratory rate $<$

$30 /$ minute (frequency/tidal volume $<65$

$1 / \mathrm{L}$ and tidal volume $>6 \mathrm{~mL} / \mathrm{kg}$ predicted

body weight) as well as normal body

temperature, no obvious bleeding or

anaemia, haemodynamic stability and ad-

equate analgesia

\begin{tabular}{|c|c|c|c|c|}
\hline $\begin{array}{l}\text { Memtsoudis } \\
2012\end{array}$ & Unspecified & Unspecified & Unspecified & Unspecified \\
\hline Park 2016a & Unspecified & $\begin{array}{l}\text { None of the participants } \\
\text { required postoperative } \\
\text { ventilatory assistance }\end{array}$ & Unspecified & Unspecified \\
\hline Sato 2016 & Unspecified & $\begin{array}{l}\text { All participants were } \\
\text { extubated in the oper- } \\
\text { ating room and were } \\
\text { spontaneously breath- } \\
\text { ing when they arrived at } \\
\text { the postanaesthesia care } \\
\text { unit }\end{array}$ & Unspecified & Unspecified \\
\hline Shen 2015 & Unspecified & Unspecified & Unspecified & Unspecified \\
\hline Soh 2018 & Unspecified & Unspecified & Unspecified & Unspecified \\
\hline Sundar 2011 & $\begin{array}{l}\text { Awake status (Riker Sedation-Agitation } \\
\text { Scale score of } 3 \text { or } 4 \text { ), haemodynamic sta- } \\
\text { bility (minimal doses of nitroglycerine } \\
\text { or phenylephrine), and adequate gas ex- }\end{array}$ & $\begin{array}{l}\text { Study ventilator settings } \\
\text { were applied immedi- } \\
\text { ately after induction of } \\
\text { general anaesthesia and }\end{array}$ & Unspecified & Unspecified \\
\hline
\end{tabular}

Intraoperative use of low volume ventilation to decrease postoperative mortality, mechanical ventilation, lengths of stay and lung injury 
Table 2. Additional information on the included studies change $\left(\mathrm{PaCO}_{2} 100 \mathrm{mmHg}, \mathrm{FiO}_{2}\right.$ 0.4, PEEP $5 \mathrm{cmH}_{2} \mathrm{O}$ )

Participants were then placed in protocol sequence; they were placed on pressure support ventilation, assessed using the rapid shallow breathing index on PEEP, receiving pressure support levels of 5 $\mathrm{cmH}_{2} \mathrm{O}$, followed by a spontaneous breathing trial of $30 \mathrm{~min}$. Participants who passed this sequence were then extubated

\section{(Continued)}

continued throughout surgery and the subsequent ICU stay
Treschan $2012 \quad$ Unspecified

\author{
Mechanical ventilation \\ of participants who were \\ transferred intubated to \\ the ICU was continued \\ according to group as- \\ signment under the dis- \\ cretion of the \\ intensivist in charge
}

Unspecified Unspecified (nates

\begin{tabular}{lllll}
\hline Weingarten 2010 & Unspecified & Unspecified & Unspecified & Unspecified \\
\hline Xiong 2016 & Unspecified & Unspecified & Unspecified & Unspecified \\
\hline Zupancich 2005 & $\begin{array}{l}\text { Participants were extubated when haemo- } \\
\text { dynamically stable, fully rewarmed, awake, } \\
\text { without surgical bleeding and with optimal } \\
\text { blood gases }\end{array}$ & $\begin{array}{l}\text { After chest closure, par- } \\
\text { ticipants were trans- } \\
\text { ferred to the ICU and } \\
\text { ventilated, with the ven- } \\
\text { tilatory pattern selected } \\
\text { randomly }\end{array}$ & Unspecified & Unspecified \\
& & & \\
& & & \\
& &
\end{tabular}

Prophylactic use of non-invasive ventilatory support was not mentioned in any of the studies.

$\mathrm{CmH}_{2} \mathrm{O}$ : centimetres of water; $\mathrm{FiO}_{2}$ : inspired fraction of oxygen; ICU: intensive care unit; min: minute; $\mathrm{mL} / \mathrm{kg}$ : millilitre per kilogram of body weight; $\mathrm{mmHg}$ : millilitre of mercury; $\mathrm{n}$ : number of participants; $\mathrm{PaCO}_{2}$ : arterial partial pressure in carbon dioxide; $\mathrm{PaO}_{2}$ : arterial partial pressure in oxygen; PEEP: positive end-expiratory pressure.

\section{AP PEN DICES}

\section{Appendix 1. CENTRAL (the Cochrane Library) search strategy}

\#1 MeSH descriptor: [Respiration, Artificial] explode all trees

\#2 MeSH descriptor: [Tidal Volume] explode all trees

\#3 ((high and low) near (tidal or volume vetilat $\left.{ }^{\star}\right)$ ) or (tidal near (modalit* or ventilat* or recruitment or expiratory or peep))

\#4 \#1 or \#2 or \#3

\#5 MeSH descriptor: [Postoperative Complications] explode all trees

\#6 MeSH descriptor: [Intraoperative Period] explode all trees

\#7 intraoperative:ti,ab or (complicat* near (pulmonary or extra?pulmonary))

\#8 \#5 or \#6 or \#7

$\# 9$ \#4 and \#8

\section{Appendix 2. MEDLINE (OvidSP) search strategy}

1. exp Respiration, Artificial/ or exp Tidal Volume/ or ((high and low) adj3 (tidal or volume vetilat*)).af. or (tidal adj3 (modalit* or ventilat* or recruitment or expiratory or peep)).mp.

2. exp Postoperative Complications/ or exp Intraoperative Period/ or intraoperative.ti,ab. or (complicat* adj3 (pulmonary or extra? pulmonary)).mp. 
3. ((randomized controlled trial or controlled clinical trial).pt. or randomized.ab. or placebo.ab. or clinical trials as topic.sh. or randomly.ab. or trial.ti.) not (animals not (humans and animals)).sh.

4. 1 and 2 and 3

\section{Appendix 3. Embase (OvidSP) search strategy}

1. artificial ventilation/ or tidal volume/ or ((high and low) adj3 (tidal or volume vetilat $\left.{ }^{\star}\right)$ ).ti,ab. or (tidal adj3 (modalit* or ventilat* or recruitment or expiratory or peep)).ti,ab. (94288)

2. postoperative complication/ or intraoperative period/ or intraoperative.ti,ab. or (complicat* adj3 (pulmonary or extra? pulmonary)).ti,ab.

3. (randomized-controlled-trial/ or randomization/or controlled-study/ or multicenter-study/ or phase-3-clinical-trial/or phase-4-clinicaltrial/ or double-blind-procedure/ or single-blind-procedure/ or (random* or cross?over* or multicenter* or factorial* or placebo* or volunteer $\left.{ }^{\star}\right)$.mp. or ((singl ${ }^{\star}$ or doubl ${ }^{\star}$ or trebl ${ }^{\star}$ or tripl $\left.{ }^{\star}\right)$ adj3 (blind ${ }^{\star}$ or mask $\left.k^{\star}\right)$.ti,ab. or (latin adj square).mp.) not (animals not (humans and animals)).sh.

4. 1 and 2 and 3

\section{Appendix 4. PsycINFO}

1. tidal volume

2. low

3. surgery

4. 1 AND 2 AND 3

\section{Appendix 5. Search strategy and results 3 January 2018}

Database: Ovid MEDLINE(R) Epub Ahead of Print, In-Process \& Other Non-Indexed Citations, Ovid MEDLINE(R) Daily and Ovid MEDLINE(R) $<1946$ to Present>

1 exp Respiration, Artificial/ or exp Tidal Volume/ or ((high and low) adj3 (tidal or volume ventilat*)).af. or (tidal adj3 (modalit* or ventilat* or recruitment or expiratory or peep)).mp. (83841)

2 exp Postoperative Complications/ or exp Intraoperative Period/ or intraoperative.ti,ab. or (complicat* adj5 (pulmonary or extra? pulmonary or postoperative or post operative)).mp. (689456)

3 ((randomized controlled trial or controlled clinical trial).pt. or randomized.ab. or placebo.ab. or clinical trials as topic.sh. or randomly.ab. or trial.ti.) not (animals not (humans and animals)).sh. (1162648)

41 and 2 and $3(715)$

Database: Embase <1974 to 2018 Week 01>

1 artificial ventilation/ or tidal volume/ or ((high and low) adj3 (tidal or volume ventilat*)).ti,ab. or (tidal adj3 (modalit* or ventilat ${ }^{\star}$ or recruitment or expiratory or peep)).ti,ab. (126624)

2 postoperative complication/ or intraoperative period/ or intraoperative.ti,ab. or (complicat* adj5 (pulmonary or extra?pulmonary or postoperative or post operative)).ti,ab. (498406)

3 (randomized-controlled-trial/ or randomization/ or controlled-study/ or multicenter-study/ or phase-3-clinical-trial/ or phase-4-clinicaltrial/ or double-blind-procedure/ or single-blind-procedure/ or (random* or cross?over ${ }^{\star}$ or multicenter ${ }^{\star}$ or factorial* or placebo* or volunteer $\left.{ }^{\star}\right)$.mp. or ((singl ${ }^{\star}$ or doubl ${ }^{\star}$ or trebl ${ }^{\star}$ or tripl $\left.l^{\star}\right)$ adj3 (blind ${ }^{\star}$ or mask $\left.{ }^{\star}\right)$ ).ti,ab. or (latin adj square).mp.) not (animals not (humans and animals)).sh. (7166088)

41 and 2 and $3(2210)$

Central

\#1 MeSH descriptor: [Respiration, Artificial] explode all trees 5841

\#2 MeSH descriptor: [Tidal Volume] explode all trees 790

\#3 ((high and low) near (tidal or volume ventilat $\left.{ }^{\star}\right)$ ) or (tidal near (modalit* or ventilat ${ }^{\star}$ or recruitment or expiratory or peep)) 1421

\#4 \#1 or \#2 or \#3 7037

Intraoperative use of low volume ventilation to decrease postoperative mortality, mechanical ventilation, lengths of stay and lung injury 
\#5 MeSH descriptor: [Postoperative Complications] explode all trees 35099

\#6 MeSH descriptor: [Intraoperative Period] explode all trees 2194

\#7 intraoperative:ti,ab or (complicat* near (pulmonary or extra?pulmonary or postoperative or post operative)) 42995

\#8 \#5 or \#6 or \#7 58434

\#9 \#4 and \#8 775

$\# 10$ \#9 in Trials 685

WHAT'S NEW

\begin{tabular}{lll}
\hline Date & Event & Description \\
\hline 4 October 2018 & Amended & Acknowledgement section amended to include Sign-off Editor \\
\hline
\end{tabular}

\section{H IST O R Y}

Protocol first published: Issue 6, 2014

Review first published: Issue 12, 2015

\begin{tabular}{lll}
\hline Date Event & Description \\
\hline
\end{tabular}

19 May $2017 \quad$ New search has been performed

The previous version contained 48 trials ( 12 included, 32 excluded, three ongoing, one awaiting classification) (Guay 2015).

We reran the search 19 May 2017.

We found 15 new trials. We excluded seven of the new trials (Arora 2017; Cui 2015; Ding 2016; Ferrando 2015; Hosten 2017; Jain 2016; Liu 2016).

Two of the new trials are ongoing (NCT01003730; NCT03157479).

We included six new trials in the review (Kuzkov 2016; Park 2016a; Sato 2016; Shen 2015; Soh 2018; Xiong 2016).

One trial that we classified as ongoing (NCT00747045) in the previous version of this review (Guay 2015), is now included (Bates 2015).

We reran the search again 3 January 2018. Two additional trials published between May 2017 and January 2018 were also added to the list of studies awaiting classification for formal evaluation at the next update. However these two last trials do not mention any outcome of interest measured in their reports.

This update contains 63 trials (19 included, 47 excluded, four awaiting classification, three ongoing)

New citation required but conclusions have not changed
Conclusions unchanged by inclusion of seven additional trials (six new trials and publication of one of the ongoing trials of the previous version).

Since the last publication, one author (SK) joined the review and no authors left the review. 


\section{CONTRIBUTIONS OF AUTHORS}

Updating the review: JG, EO, SK.

Co-ordinating the review: JG.

Screening search results: JG, SK.

Organizing retrieval of papers: JG.

Screening retrieved papers against inclusion criteria: JG, SK.

Appraising quality of papers: JG, SK.

Abstracting data from papers: JG, SK.

Writing to authors of papers for additional information: JG.

Data management for the review: JG.

Entering data into Review Manager 5 (Review Manager 2014): JG.

Review Manager 5 statistical data: JG.

Other statistical analysis not using Review Manager 5: JG.

Interpretation of data: JG, EO, SK.

Statistical inferences: JG.

Writing the review: JG, EO, SK.

Securing funding for the review: departmental resources only.

Performing previous work that was the foundation of the present update: JG, EO, SK.

Guarantor for the review (one author): JG.

Person responsible for reading and checking review before submission: JG, EO, SK.

\section{DECLARATIONSOF INTEREST}

JG: I receive fees as an Associate Professor for a course on airway management at the University of Quebec in Abitibi-Temiscamingue.

EO: I have had no direct relationship with any equipment manufacturer or pharmaceutical company since 2007 . I do not hold any stocks or shares other than mutual funds. I have participated as an expert witness in medical legal cases and patent cases.

Sandra Kopp: no conflict of interest.

\section{SOURCES OF SUPPORT}

\section{Internal sources}

- University of Montreal, Canada.

University of Montreal granted access to electronic databases and to major medical journals

- University of Quebec in Abiti-Temiscamingue, Canada.

University of Quebec in Abiti-Temiscamingue provided access to electronic databases and medical journals.

- Cochrane Anaesthesia Review Group, Denmark. 
The authors wish to thank Karen Hovhannisyan who designed the search strategy and Janne Vendt who updated the search.

- University of Sherbrooke, Canada.

University of Sherbrooke granted access to electronic databases and to major medical journals.

- University of Pennsylvania, USA.

University of Pennsylvania granted access to electronic databases and to major medical journals.

- Laval University, Canada.

Laval University granted access to electronic databases and to major medical journals

\section{External sources}

- No sources of support supplied

\section{DIFFERENCES BETWEEN PROTOCOLANDREVIEW}

\section{7}

1. One author (SK) joined the review.

Differences between the protocol (Nguyen 2014), and the review (Guay 2015)

1. The protocol stated: mortality within seven days and within 30 days after surgery. However, only one study with no events provided results specifically within seven days after surgery. Therefore, we decided to include all the relevant available information (in hospital or within 30 days) and considered it as within 30 days after surgery.

2. The protocol stated that we would look inAnesthesiology for abstracts of the American Society of Anesthesiologists but these abstracts are archived on the website of the society. Therefore, we looked on the website of the American Society of Anesthesiologists instead.

3. The protocol stated that publication bias would be examined with the classical fail-safe number (fewer than 10 studies) or a funnel plot followed by the Duval and Tweedie's trim and fill technique for each outcome (10 studies or more). However, the classical fail-safe number will always be zero when there is no effect and the software (Comprehensive Meta-analysis) will provide an adjusted effect of estimate for any result with three studies or more. Therefore, we decided to use the Duval and Tweedie's trim and fill technique only for publication bias assessment.

4. Dat Nhut Nguyen was coauthor for the protocol of this review (Nguyen 2014).

\section{N DEX TERMS}

\section{Medical Subject Headings (MeSH)}

${ }^{\star}$ Tidal Volume; Acute Lung Injury [*etiology] [prevention \& control]; Barotrauma [diagnosis] [etiology]; Body Weight; Hospital Mortality; Insufflation [adverse effects] [methods]; Intensive Care Units [statistics \& numerical data]; Intraoperative Care [methods]; Length of Stay [ ${ }^{\star}$ statistics \& numerical data]; Noninvasive Ventilation [statistics \& numerical data]; Pneumonia [epidemiology] [prevention \& control]; Positive-Pressure Respiration [adverse effects] [ ${ }^{*}$ methods] [mortality]; Postoperative Care [statistics \& numerical data]; Pulmonary Atelectasis [etiology] [therapy]; Randomized Controlled Trials as Topic

\section{MeSH check words}

Adult; Aged; Female; Humans; Male; Middle Aged 